Portland State University

PDXScholar

Spring 6-17-2013

\title{
Disruptions in the Dream City: Unsettled Ideologies at the 1905 World's Fair in Portland, Oregon
}

Kat Cleland

Portland State University

Follow this and additional works at: https://pdxscholar.library.pdx.edu/open_access_etds

Part of the African American Studies Commons, Asian American Studies Commons, and the Indigenous Studies Commons

Let us know how access to this document benefits you.

\section{Recommended Citation}

Cleland, Kat, "Disruptions in the Dream City: Unsettled Ideologies at the 1905 World's Fair in Portland, Oregon" (2013). Dissertations and Theses. Paper 1019.

https://doi.org/10.15760/etd.1019

This Thesis is brought to you for free and open access. It has been accepted for inclusion in Dissertations and Theses by an authorized administrator of PDXScholar. Please contact us if we can make this document more accessible: pdxscholar@pdx.edu. 
Disruptions in the Dream City:

Unsettled Ideologies at the 1905 World's Fair in Portland, Oregon

\author{
by \\ Kat Cleland
}

A thesis submitted in partial fulfillment of the requirements for the degree of

Master of Arts

in

History

Thesis Committee:

Patricia A. Schechter, Chair

Richard H. Beyler

Chia Yin Hsu

Carl Abbott

Portland State University

2013 
(C) 2013 Kat Cleland 


\begin{abstract}
This thesis examines the experiences of fairgoers at the Lewis and Clark Centennial, American Pacific Exposition and Oriental Fair held in Portland, Oregon from June to October of 1905. Historians have framed world's fairs and international expositions as sites of legitimating narratives and restagings of empire and nationhood. This thesis focuses on women, Asian Americans, and Native Americans who interrupted and disrupted the performance and exhibition of U.S. imperialism in the specific case of Portland, Oregon. It considers who benefitted from or endured loss in the demonstrations of imperial culture at the Fair. Following the premise that metropolitan and colonial histories should be considered in the same analytical field, and that the systemic power of domestic imperialism in the United States extended beyond Native Americans into the experiences of most nonwhite American communities, this thesis adds a metropolitan approach to Native-American history and, in turn, applies a more colonial approach to the study of African-American, Asian-American, and working-class women's histories. In three chapters, this study also extends beyond the categories of nation and empire, colony and metropole to present a transnational study of disruptions at the 1905 Lewis and Clark Centennial downplayed by the Exposition's organizers and overlooked by previous historians of the Fair to shed light on the construction, tension, and negotiation of race, class, and gender identities in the turn-of-the-century West.
\end{abstract}




\section{Table of Contents}

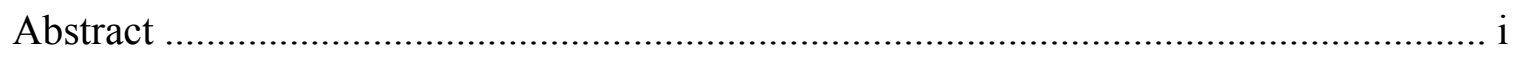

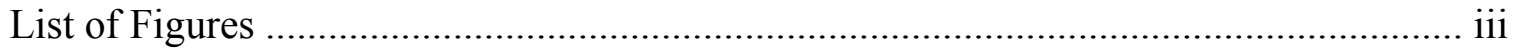

Introduction

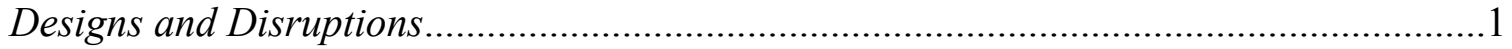

Chapter One

Designs of a Feminine Past, Disruptions of a Native Presence ......................................16

Chapter Two

Designs of the 'Fair' Orient, Disruptions from Chinatown ........................................ 54

Chapter Three

Designs of Urban Maternalism, Disruptions of Rural Modernity ................................. 95

Conclusion

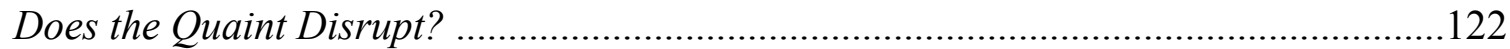

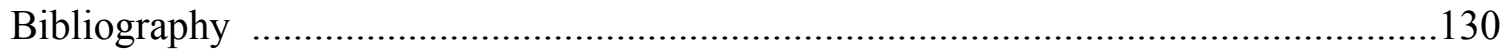




\section{List of Figures}

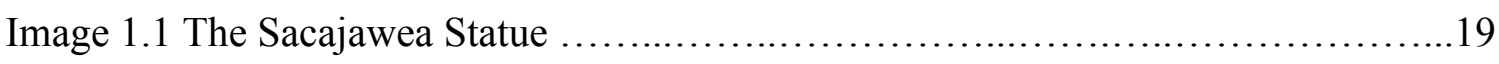

Image 1.2 Lady Progress Seal.................................................. 27

Image 1.3 Eva Emery Dye with Walla Walla Women..............................45

Image 1.4 The Indian Village.............................................47

Image 2.1 Igorrote tribesmen and their American spectators........................59

Image 2.2 Visayan Weavers...............................................61

Image 2.3 Scene in Fair Japan ...............................................69

Image 2.4 The American-Born Chinese Brigade on Parade.......................... 78

Image 2.5 Men From Every Clime at the Fair.................................... 85

Image 2.6 A Bunch of Portland Chinese Doin' the Trail............................85

Image 2.7 Camel Ride on the Streets of Cairo.................................... 91

Image 2.8 Vaudeville Orientalism......................................... 92

Image 3.1 Souvenir Sue................................................ 107

Image 3.2 Place of Rest and Comfort: YWCA Exposition Building....................110 


\section{Introduction: Designs and Disruptions}

On July 7, 1905 the Sacajawea and Red Men Parade passed through downtown Portland, Oregon. As it winded through the city's downtown, the colorful, cross-dressed procession of carriage-drawn women suffragists, white men in Indian costume, and Indian boys in military uniform marched through several blocks of the city's Chinatown. After passing through the southwest riverfront blocks, they headed to the trolley station where they boarded streetcars to the Lewis and Clark Centennial, American Pacific Exposition, and Oriental Fair, situated in the northern part of the city. ${ }^{1}$ The local police noticed and arrested two young boys from the Chemawa School, the institution that had trained the parade's juvenile soldiers, who had joined the spectators lining the streets to watch the parade. The boys had left the school located near Salem, Oregon, without authorization several days before and traveled over forty miles to get to Portland. The boys' escape, their unsanctioned mobility, and their public arrest subtly disrupted the parade's overwhelming imagery of Native-American submission to U.S. national progress and colonial rule. One local newspaper clarified some of the contours of the boys' disruption in an attempt to isolate and diminish its significance. Claiming the boys had escaped Chemawa out of eagerness to see the city's celebration of Native America,

\footnotetext{
1 “Red Men March Through Streets," Oregonian, July 7, 1905, p. 10. The Oregonian included the parade route in its coverage of the Sacajawea and Red Men Day ceremonies. When traced onto maps of the city's downtown business and residential district, the parade passed numerous blocks occupied by Chinese Portlanders. See Marie Rose Wong, Sweet Cakes, Long Journey: The Chinatowns of Portland, Oregon (Seattle: University of Washington Press, 2004), 252, 259 for maps of Portland's early twentieth-century Chinatowns.
} 
and reassuring its readers that local and federal authorities swiftly returned the boys to the institution, the Oregonian implied the disruption actually reinforced the Fair's order. The remaining Chemawa students, the Oregonian reported, would be kept "under the strictest military rule" during their time at the Exposition. ${ }^{2}$ Scenes that confused the historical narratives prescribed in the performances, exhibits, parades, and ceremonies of the 1905 Lewis and Clark Exposition occurred throughout the Fair's June-to-October run. As the parade suggests, these stagings and disruptions spilled out of the fairgrounds into the city proper.

This thesis traces the experiences of laborers, artisans, performers, social activists, and consumers at the Lewis and Clark Exposition who asserted identities that to varying degrees undermined the Fair's dominant worldview. The Exposition's latent racialized and gendered designs supported social and systemic exclusions and discriminations within an overarching story of nation and empire. Not necessarily congruent or equal to one another, and not always completely incongruent with the dominant messages of the Exposition, disruptions called into question the rigidity of categories such as race, gender, nation, and ethnicity, classifications central to the themes of the "American Pacific

\footnotetext{
2 "Red Men March Through Streets," Oregonian, July 7, 1905, p. 10; "Indian Boys Run Away," Oregonian, July 7, 1905, p. 16; United States Office of Indian Affairs, Rules for the Indian School Service (Washington, D.C.: Government Printing Office, 1898), 6-7. The white Red Men were members of the Improved Order of Red Men, a national middle-class fraternal organization with local "tribes" throughout the Pacific Northwest. Once enrolled, proclaimed the U.S. Department of the Interior, any student who left Indian training institutions "without proper authority" had to be returned to the school regardless of objections by "any parent, guardian, or other person," family members and friends who also risked arrest for "harboring the pupil." Another regulation allowed federal Indian agents to "withhold rations, clothing, or annuities from parents or guardians" if they refused to surrender their children to the institutions. Rather than education and uplift, the terms incarceration and coercion better describe federal Indian schools in the United States during the nineteenth and early-twentieth centuries.
} 
Exposition and Oriental Fair." Defined as an interruption or disturbance of events, activities, or processes, disruption is employed in this examination of the Exposition to delineate a range of counteractive performances, texts, speeches, social exchanges, as well as labor and consumer practices that - with varying degrees of intention and success - disturbed the dominant ideologies underlying the management of race and gender at the Exposition and in the city. While a number of historians have documented elite white women's participation in world's fairs and have explored gender issues that played out in U.S. international expositions, this thesis reframes questions of women and gender more explicitly around empire and critical race perspectives. ${ }^{3}$ Contrasts or contradictions to the Exposition's image of a "Dream City" on an American Pacific Rim settled, civilized, and developed by white pioneers, manifested in various ways with different degrees of intention and success. ${ }^{4}$ Snags in the fabric of the Exposition, disruptions were often

\footnotetext{
${ }^{3}$ For histories of women and gender at international expositions see Jeanne Madeline Weimann, The Fair Women (Chicago: Academy Chicago, 1981); T. J. Boisseau and Abigail M. Markwyn, eds., Gendering the Fair: Histories of Women and Gender at World's Fairs (Urbana: University of Illinois Press, 2010); Laura Wexler, "The Fair Ensemble: Kate Chopin in St. Louis in 1904," in Ann Laura Stoler, ed., Haunted By Empire: Geographies of Intimacy in North American History (Durham: Duke University Press, 2006); Deborah M. Olsen, "Fair Connections: Women's Separatism and the Lewis and Clark Exposition of 1905," Oregon Historical Quarterly 109, no. 2 (Summer 2008): 174 - 203. A world history of colonial subjects at world's fairs in North American, European, and Asian contexts includes Paige Raibmon, Authentic Indians: Episodes of Encounter from the Late Nineteenth-Century Northwest Coast (Durham: Duke University Press, 2005); Raibmon, "Theatres of Contact: The Kwakwaka'wakw Meet Colonialism in British Columbia at the Chicago World's Fair," Canadian Historical Review 81, no. 2 (2000): 157 - 190; Pascal Blanchard, et al., eds., Human Zoos: Science and Spectacle in the Age of Colonial Empires (Liverpool: Liverpool University Press, 2008); Gyan Prakash, "Science 'Gone Native' in Colonial India," Representations 40 (Autumn, 1992): 153 - 178; Hong Kal, "Modeling the West, Returning to Asia: Shifting Politics of Representation in Japanese Colonial Expositions in Korea," Comparative Studies in Society and History 47, no. 3 (July 2005): 507 - 531; Patricia A. Morton, "National and Colonial: The Musée des Colonies at the Colonial Exposition, Paris, 1931," Art Bulletin 80, no. 2 (June 1998): 357-377.

4 "Dream City" appeared in headline of an Oregonian article that appeared on June 8, 1905. The full title, "Wheat And Wool Rule The Fair: Eastern Oregon People Merrily Invade the Dream
} 
patched over by local journalists who preferred to adjust the dominant narrative rather than explore the complexity of cultural identity at the Exposition and in Portland. Once patched over, disruptions appeared as curious, picturesque, or quaint deviations from the civilizational schema for an American Pacific. This thesis studies many patched-over disruptions at the Lewis and Clark Exposition and Oriental Fair in order to draw out nonelite perspectives, however muffled.

Located in a rapidly growing city and in a region recently seized from and still inhabited by Native Americans, the Fair provides a unique opportunity to examine the West, Oregon, and the city of Portland as metropolitan and colonial entities. This study situates the Exposition in a frontier-like urban space where Native American and European American fairgoers interacted through commercial, economic, and social exchanges. Blurring colony and metropole clarifies the ways in which federal and municipal authorities, as well as numerous social reformers, missionaries, and educators regulated the mobility and participation of Native Americans at the Fair. Placing the metropole of Portland in a colonial context also illuminates the experiences of Portland's urban Asian Americans who, like Native Americans, encountered a highly racialized and hierarchical portrayal of the Orient at the Fair that seemingly upheld allegations that despite their longtime presence in the West, Asian Americans lacked the capacity to assimilate and thus should be excluded from citizenship. Disruptions also become more apparent once identifying the Exposition as a diverse contact zone. Recast pioneer

City," described multiple agricultural exhibits available to - and made available by - the large numbers of non-Portland Oregonians who traveled to the Exposition. Rural producers received payment for items like wool, wheat, fruits, and vegetables for display in the Fair's county exhibits. 
identities, nonconventional appearances and behaviors, and unauthorized mobility disturbed attempts to regulate not only the Native Americans appearing in chapter one, but also the Asian Americans of chapter two, and the working-class and rural women of chapter three. ${ }^{5}$

\section{Designs}

The project of a mere industrial and trade exposition will not itself engage much attention in the East; those things are too common nowadays. But the historical and sentimental side of it is important and will bring support from quarters that would find no interest whatever in the ordinary exposition of industries and trade.

-The Oregonian, November 28, 1902

Local white businessmen dominated the "industrial and trade" aspects of the Fair; this thesis, however, focuses on the "historical and sentimental" side, a domain involving a wider range of historical actors and expressions relating to the issues of identity, history, and social relations. Bank president and former U.S. senator, Henry W. Corbett, along with Oregonian newspaper editor Harvey Scott and J. M. Long of the Portland Board of Trade began planning the Exposition in 1901 as a businesslike community enterprise. After securing an endorsement and financial aid from the Oregon state

\footnotetext{
${ }^{5}$ Ann Laura Stoler and Frederick Cooper, "Between Metropole and Colony: Rethinking a Research Agenda," in Stoler and Cooper, eds., 1 - 56, Tensions of Empire: Colonial Cultures in a Bourgeois World (Berkeley: University of California Press, 1997); Stoler, ed. Haunted By Empire: Geographies of Intimacy in North American History (Durham: Duke University Press, 2006). Comparative studies of colonial cultures found in anthologies compiled by Ann Laura Stoler have established continuities between the social and legal mores that regulated European and European-American metropoles and those that governed their colonies. In the U.S. context, the incorporation of Native American, Hawaiian, and Alaskan land and people into the nation as states blurred the distinction between metropole and colony.
} 
legislature, the coalition of Portland civic elites proceeded to gather additional support through additional regional, national, and international political and corporate bodies.

The organizers primarily saw the Fair as an opportunity to boost the city's economic and infrastructural development and as a means to attract investment in Portland's various industries. They also regarded the enterprise as an opportunity to advertise of the city's urban development by promoting contemporary and future building projects such as suburban expansions, streetcar systems, universities, parks, and other public spaces of popular appeal. The Exposition joined local interests with those of the state largely through the influence of the Lewis and Clark Centennial Exposition Commission, a body designated by the legislature that funded and managed the Oregon state and county exhibits. Displays of Oregon's abundant natural resources and its varied industries and manufactures dominated the Fair. ${ }^{6}$ Local organizers acquired financial aid, buildings, and exhibits from other western states by emphasizing the Fair as an opportunity to place "the West itself...on exhibition with all its matchless scenery and its products of farm, forest, factory, and mines." In a letter sent to the legislatures of Washington, Idaho, North and South Dakota, Montana, and Wyoming, the Exposition's executive board wrote

\footnotetext{
${ }^{6}$ Carl Abbott, The Great Extravaganza (Portland: Oregon Historical Society, 1981), 13 - 17; Leslie's Weekly: Lewis and Clark Centennial Exposition Issue (New York, June 22, 1905), p. 582, in Lewis \& Clark Centennial Exposition Records, Mss 1609, box 123, folder 12, Oregon Historical Society Research Library [hereafter cited as Mss 1609]. Carl Abbott's study of the Exposition provided an extensive account of the Fair's overall management, construction, and economic impact. The Fair's executive board included a mixture of civic leaders, representatives from the Board of Trade, the Chamber of Commerce, and the Manufacturers Association who joined legal and financial advisors to head the corporation. Prominent businessmen, including Corbett, took out stock in the Exposition, as did railroad and streetcar companies, banks, hotels, restaurants, breweries, and retail outlets. Federal support came in the form of an aid bill passed in April of 1904 that allotted $\$ 475,000$ to the construction of a U.S. government building and exhibits. The Portland delegation that went to Washington, D.C. to secure authorization and financial aid originally proposed a $\$ 2,125,000$ budget.
} 
"Nothing that has occurred since the discovery of gold in California will so attract attention to the West and its wonderful capabilities for home building and industry as the Lewis and Clark Exposition of 1905." Americans living in "the East," the letter continued, who lacked "the cheap land that in generations past was its chief inducement to the homeseeker, now appreciated the West and realizes its value to an expanding country.", In their promotion of the regional and national corollaries to the predominately local enterprise, the Exposition's organizers designed an image of a modern metropolis linked to the industrial and agricultural bounties of the region that enhanced national and international commerce, productivity, and progress.

The Portland Fair connects to a broader U.S. and world history of expositions, fairs, and exhibitions. In his study of early American world's fairs, historian Robert W. Rydell argued that all international expositions held between 1876 and 1916 set out "to boost the economic development of the cities and regions in which they were held as well as to advance the material growth of the country at large." ${ }^{\prime 8}$ Rydell additionally showed that expositions served less concrete ideological functions, and argued that localized analyses of the fairs reveal differences in their practical and thematic content. The statues, architecture, scientific spectacles, and patriotic performances at the Portland Fair offered visible, material representations and symbols to categorize and characterize national, imperial, and civilizational identities. The added touristic draw of these attractions buttressed the goal of economic development. According to Rydell, the varied exhibits and amusements arranged by the organizers of world's fairs aggregated to form a

\footnotetext{
${ }^{7}$ Letter from the Board of Directors to the Western States, Mss 1609, box 12, folder 5.

${ }^{8}$ Robert W. Rydell, All The World's A Fair: Visions of Empire at American International Expositions, 1876 - 1916 (Chicago: University of Chicago Press, 1984), 2.
} 
"symbolic universe," or what historian Laura Wexler has described as a "fair ensemble."

Defined as a "social vision that linked personal goals of a select few with general historical advancement of the entire world," and a "structure of legitimation that provides meaning for social experience," the fair ensemble at the Portland Fair manifested through a series of performances, images, and texts that linked the historic efforts of the 18041806 Lewis and Clark expedition to the region's contemporary progress, and to future U.S. expansionism into Asia and the Pacific. ${ }^{9}$

Native America and the Orient had long been thematic aspects of U.S. international expositions by the time of the Portland Exposition in 1905; however, several factors distinguished Portland's use of Native-American and Oriental themes from those constructed at previous expositions. ${ }^{10}$ U.S. military battles against Native Americans in the West had subsided about two decades before the Fair and new federal institutions and Reservations had come to replace military violence as the modes of colonial power. These factors influenced the historic and contemporary portrayals of Native Americans at the Exposition, and they compose the disrupted designs analyzed in chapter one of this study. Chapter two discusses the Fair's Orientalist framework and the problematic positions of Asians and Asian Americans within it. The more engaged focus on the

\footnotetext{
${ }^{9}$ Laura Wexler found the phrase "fair ensemble" in the family memoirs of southern writer Kate Chopin. Wexler, "The Fair Ensemble, 281; Rydell, All The World's A Fair, 2-3, 185; Shelley Sang-Hee Lee, Claiming the Oriental Gateway: Prewar Seattle and Japanese America (Philadelphia: Temple University Press, 2011), 9, 54. Rydell and Lee identify the West Coast world's fairs of the early twentieth-century as distinctive from previous U.S. expositions in their heightened emphasis on the future of the nation-state.

${ }^{10}$ For additional studies of the portrayal of Asia and the Orient at U.S. world's fairs, see Rydell, All the World's a Fair, 29-31, 165-175; Gary Y. Okihiro, Common Ground: Reimagining American History (New Jersey: Princeton University Press, 2001); Lisa K. Langlois, "Japan Modern, Ancient, and Gendered at the 1893 Chicago World's Fair," in Boisseau and Markwyn, Gendering the Fair, 56-74.
} 
Orient at the Portland Fair derived from its geographic proximity to Asia and the Pacific and its occurrence during an era in which the United States overtook, fortified, and enforced claims over land and people in the Pacific Rim, including Hawaii, Alaska, and the Philippines. The Fair additionally coincided with Japan's victory in the RussoJapanese war, a feat that disturbed European and U.S. designs on Asia and that influenced the portrayal and reception of Japan at the Fair.

The Fair's orientation towards a new far western frontier in the so-called Far East implicated the event in constructing the Pacific Rim for a U.S. imperial imaginary. Framing the region as a geographical space governed by U.S. cultural, political, economic, and military prerogatives, the Fair minimized the gulf between the Far West and the Far East by designing the Pacific Ocean as an "American Lake."11 Historians have used terms similar to the symbolic universe and fair ensemble of Rydell and Wexler to conceive of how European and European-American scholars and politicians mapped Asia and the Pacific according to Western European perspectives that largely misrepresented indigenous spatial and collective-identity concepts. In his study of the Philippines, historian Vicente Rafael, for example, described the application of nonindigenous geographic and collective identities to colonized people as a means for imperialists and nationalists to establish a "conceptual possession" over territories and their inhabitants. ${ }^{12}$ In an extension of Edward Said's Orientalism to include analyses of gender and the United States, historian Joan Jensen described the Pacific Rim as an

\footnotetext{
11 “Our Empire on the Pacific," New York: Leslie's Weekly: Lewis and Clark Centennial Exposition Issue, June 22, 1905, Mss 1609, box 123, folder 12.

${ }^{12}$ Vicente L. Rafael, White Love and Other Events in Filipino History (Durham: Duke University Press, 2000), 5, 18.
} 
"artificial construct, an imaginary map that at its fullest includes the Americas, East Asia, the islands of the South Pacific, and, to the north, Russia" wherein white women wielded colonial power through the collection and display of Asian art, textiles, and clothing.

Jensen's study additionally considered Asian and Asian-American consumers, producers, and merchants to reveal a more complicated dispersal of power and a deeper, more dynamic Asian influence upon American clothing styles, material culture, and artistic forms. Tracing the experiences of both white and Asian women who blurred and crossed the East-West divide, Jensen provided an apt framework for this study's reconsideration of Portland's Oriental Fair. ${ }^{13}$

\section{Disruptions:}

Disruptions at the Exposition ranged from reinterpretations of the Exposition's dominant designs to expressions of disinterest in them. Chapter one will approach the ways in which white women suffragists employed the public spaces of the Fair to weaken the masculine stronghold on pioneer identity, civilizational power, and imperial administration. Their presentations framed women as active and essential participants in the mutually constitutive projects of national expansion and empire building. Through performances and rhetoric that portrayed white women as municipal and imperial mothers, suffragists presented a twentieth-century pioneer womanhood as a sort of unique

\footnotetext{
${ }^{13}$ Joan M. Jensen, "Women on the Pacific Rim: Some Thoughts on Border Crossings," Pacific Historical Review 67, no. 1 (Feb. 1998): 5; Kristin L. Hoganson, Consumer's Imperium: The Global Production of American Domesticity, 1865 - 1920 (Chapel Hill: University of North Carolina Press, 2007). Hoganson identified how white women's consumer, intellectual, and ethnographic pursuits into the so-called Orient and Native America bolstered their social, professional, and economic identities, often without leaving the country.
} 
regional new womanhood that they used to argue for women's expanded public and professional power and to include frontier women in a national, commemorative landscape. ${ }^{14}$ Until the Portland Exposition, as historian Deborah Olsen has shown, administrators of U.S. world's fairs repeatedly undermined attempts made by suffragists to bring the debate over women's rights to the stages of international expositions. ${ }^{15}$ The socio-political context of the West, and specifically Oregon, made it easier for white women to interrupt administrative authority through unofficial but well-established and well-endowed social networks. Coalitions of women's clubs with significant financial resources and political alliances propelled numerous white women social activists into positions of professional and political power at the Fair. ${ }^{16}$

The world's fairs held on the West Coast in the early twentieth century largely ignored the influence of Asian Americans on the physical development and cultural

\footnotetext{
${ }^{14}$ For an analysis of anti-suffrage Pioneer Womanhood, see Brenda D. Frink, "San Francisco's Pioneer Mother Monument: Maternalism, Racial Order, and the Politics of Memorialization, 1907 - 1915," American Quarterly 64, no. 1 (2012): 85 - 113. On women's participation in public portrayals of the pioneer past, see Michael Heffernan and Carol Medlicot, "A Feminine Atlas? Sacagawea, the Suffragettes and the Commemorative Landscape in the American West, 1904 1910," Gender, Place and Culture 9, no. 2 (2002), 109 - 131.

${ }^{15}$ Deborah M. Olsen, "Fair Connections: Women's Separatism and the Lewis and Clark Exposition of 1905," Oregon Historical Quarterly 109, no. 2 (Summer 2008): 174 - 203. For an analysis of suffragists at the 1893 Chicago World's Fair, see Jeanne Madeline Weimann, The Fair Women (Chicago: Academy Chicago, 1981). Despite the presence of a Woman's Pavilion at the Philadelphia Centennial, the all-male organization committee refused Elizabeth Cady Stanton and Susan B. Anthony's request to present the "Declaration of Rights of Women." Anthony and Cady Stanton presented the declaration anyway outside the fairgrounds. At the Chicago World's Fair, male organizers similarly denied the request of local suffragists to host a woman's congress on the fairgrounds. The Chicago women also carried out their plan off the fairgrounds. ${ }^{16}$ Olsen, "Fair Connections," 176, 180 - 189; Lisa Blee, "Completing Lewis and Clark's Westward March: Exhibiting a History of Empire at the 1905 Portland World's Fair," Oregon Historical Quarterly 106, no. 2 (Summer 2005): 232 - 253. For more on the popularity of suffrage in the West, see Kimberly Jensen, "Revolutions in the Machinery: Oregon Women and Citizenship in Sesquicentennial Perspective," Oregon Historical Quarterly 110, no. 3 (Fall 2009): 336 -361 and Rebecca J. Mead, How the Vote Was Won: Woman Suffrage in the Western United States, 1868 - 1914 (New York: New York University Press, 2004).
} 
identity of the region. The largest populations of Chinese and Japanese Americans in the United States lived in the cities of Portland, Seattle, and San Francisco when they hosted world's fairs in 1905, 1909, and 1915. Indeed, each of the West Coast fairs referred to the Pacific or Asia in its central theme. Seattle, Washington followed the Portland Exposition's American Pacific and Oriental Fair with an Alaska-Yukon-Pacific Exposition in 1909 and San Francisco dipped south with a Panama-Pacific theme in 1915. Historians have identified Japan and China as the points-of-origin for many eastward-moving Asian pioneers who forged transnational identities in the American West that were characterized by a mixture of national, regional, and local affiliations. ${ }^{17}$ Portland's reputation as a haven for Chinese Americans on the West Coast and its multigenerational, multi-origin, and multi-lingual Asian population did not go unnoticed at the Fair. Chapter two considers Chinese Portlanders as well as Japanese and Filipino performers and consumers in order to uncover disruptions that unsettled the Fair's portrayals of a static, ancient Orient located on a western U.S. frontier. ${ }^{18}$

This study stretches beyond colony, metropole, and frontier to situate world's fairs in transnational and decolonial contexts where national and colonial power

\footnotetext{
${ }^{17}$ Paul G. Merriam, "The 'Other Portland': A Statistical Note on Foreign-Born, 1860 - 1910," Oregon Historical Quarterly 80 (Fall 1979): 266-268. The Seattle and San Francisco fairs also idealized U.S. relations with Native Americans in addition to those with China and Japan to imagine a benevolent American empire on the Pacific Rim. See Abigail M. Marwyn, "Encountering 'Woman' on the Fairgrounds of the 1915 Panama-Pacific Exposition," in Boisseau and Markwyn, Gendering the Fair, 169-186 and Lee, Claiming the Oriental Gateway, 51-62. Lee explored the discrepancy between the celebration of Japan at the fair and the contemporaneous legal and social discriminations against Japanese Americans who lived in the city of Seattle at the time of the Exposition.

${ }^{18}$ Eiichiro Azuma, Between Two Empires: Race, History, and Transnationalism in Japanese America (New York: Oxford University Press, 2005); Gary Y. Okihiro, Common Ground: Reimagining American History (New Jersey: Princeton University Press, 2001); Wanni W. Anderson and Robert G. Lee, eds., Displacements and Diasporas: Asians in the Americas (New Brunswick: Rutgers University Press, 2005).
} 
structures remain active but lose centricity. Ann Laura Stoler's anthology Haunted By

Empire used gender and the concept of "intimacies of empire" to show the colonial

nature of laws, practices, and institutions not typically associated with U.S. imperialism such as the management of slaves and free blacks in white residences of the South, laws against interracial marriage and Asian immigration, and through systems like Jim Crow, the Freedman's Bureau, the Bureau of Indian Affairs, and those that regulated workingclass and non-Western-European immigrant women, such as settlement houses and domestic training schools. ${ }^{19}$ These varied systems of management and "uplift" ruptured family and marriage arrangements, clothing and material preferences, labor and parenting practices - the "intimacies of empire" - and sought to replace them with mainstream Anglo-American behaviors and appearances. Taking this expanded, intimate domain of empire into consideration, chapter three will analyze the experiences of working-class

\footnotetext{
${ }^{19}$ Stoler, Haunted By Empire, 28; "An Act to Prohibit Amalgamation and the Intermarriage of Races," 1866, Or. Gen. Laws 10, quoted in Peggy Pascoe, What Comes Naturally: Miscegenation Law and the Making of Race in America (Oxford: Oxford University Press, 2009), 8. Colonial designs in the West can also be conceived of in terms of their similarities the South. Peggy Pascoe's study of anti-miscegenation laws, for example, uncovered a series of white supremacist laws in the territorial and state constitutions of the American West to challenge the democratic nature of Progressivism in the West, to rethink the South's reputation as the primary source of racism in the United States, and to expand beyond the black-white paradigm of U.S. race relations. Oregon's constitution prohibited intermarriage between "any white person, male or female" and "any negro, Chinese, or any person having one fourth or more negro, Chinese, or kanaka blood, or any person having more than one half Indian blood. Laura Wexler's analysis of the 1904 St. Louis World's Fair identified in the exhibits of southern history a "nationalist fervor" for a "new imperial order" that "transformed both the resistant sectionalism of the Old South and the resilient commercialism of the New beyond all possibility of imagining in the nineteenth century." Similarly, portrayals of the Old West at the Lewis and Clark Exposition situated Portland in a new era of nation-building within what historian of Native-American history Elliott West identified as the "Greater Reconstruction." The Fair imposed a national character upon a geographic region that had, in the previous century, disrupted federal authorityWexler, "The Fair Ensemble," 280; Elliott West, The Last Indian War: The Nez Perce Story (Oxford: Oxford University Press, 2009), $288-292$.
} 
and rural women at the Exposition as well as the efforts of middle-class urban women to monitor, document, and influence working-class and rural women's experiences at the Fair. $^{20}$

The performance of disruption at world's fairs transcended the fairgrounds into the city. They appeared in informal acts of work and consumption performed by fairgoers whose identities did not fit neatly into the Exposition's Eurocentric and paternalistic conceptions of local and national identity. In their studies of women and empire, historians like Joan Jensen and Patricia A. Schechter have identified expressions of what Puerto Rican feminist theorist Emma Pérez has termed a "decolonial imaginary." More fully defined by Schechter as disruptions of the "dominant ordering schemas of modern society, especially the binaries of colonizer/subaltern and citizen/alien," decolonial consciousnesses often hide in more fragmented and less articulate forms than nationalist and imperialist subjectivities. ${ }^{21}$ One example to the contrary, of a well-articulated transnational identity, appeared in the late-nineteenth and early-twentieth-century writings of the Anglo-Chinese woman Sui Sin Far. Her expression of a Eurasian pioneer identity provides an apt introduction to this study's discussion of disrupted ideologies.

\footnotetext{
20 "Life Intensified in the Cities: Problem Is to Improve Civic Conditions for Everybody," Oregonian, August 16, 1905, p. 10; General Laws of Oregon, vols. 1903 - 1913 (Salem: State of Oregon), $180-182$. Portland urban reformers successfully helped the passage of the protective labor law of 1903, which set a ten-hour-maximum limit on the hours women were allowed to work "in any mechanical or merchantile establishment, laundry, hotel, or restaurant," but failed to do address poor labor conditions and wages. Domestic employment was not included in the law. ${ }^{21}$ Emma Pérez, The Decolonial Imaginary: Writing Chicanas into History (Bloomington: Indiana University Press, 1999), xiii - xix; Patricia A. Schechter, "Feminist Approaches to AntiImperialism: A Case for the Decolonial," Conference paper, American Anti-Imperialism since 1776, University of Oxford, Oxford, UK, April 29 - 30, 2011, p. 8; Jensen, "Women on the Pacific Rim," 14. Jensen discussed the 1991 art installation "deColonization" created by the Korean-American woman Yong Soon Min that appeared in the New York Bronx Museum.
} 
Sui Sin Far, originally named Edith Maude Eaton, traveled between Seattle and Los Angeles as a journalist during the time of the Portland Exposition. Her autobiographical essay, "Leaves from the Mental Portfolio of an Eurasian," challenged temporal and spatial separations of the Orient and the Occident by dissolving the racial essentialism of national communities. Doing away with the nation-state in favor of a hybridizing, transnational approach, Sui Sin Far wrote, "I believe that someday a great part of the world will be Eurasian, I cheer myself with the thought that I am but a pioneer. A pioneer should glory in suffering...I have no nationality and am not anxious to claim any. Individuality is more than nationality." 22 In accordance with Sui Sin Far's pioneer identity wherein individual choices and fused cultural identities outweighed the significance of nationalism, the chapters that follow syncopate the history of the 1905 Exposition in order to displace the Fair's loud, hegemonic beats and elucidate quieter articulations of transnational and decolonial identities at the Portland Exposition.

\footnotetext{
${ }^{22}$ Sui Sin Far, "Leaves from the Mental Portfolio of an Eurasian," originally published in the New York Independent, January 21, 1909, reprinted in Amy Ling and Annette White-Parks, eds., Mrs. Spring Fragrance and Other Writings (Urbana: University of Illinois Press, 1995), 224.
} 


\section{Chapter One \\ Designs of a Feminine Past, Disruptions of a Native Presence}

Sacajawea led them all, the dark-eyed princess of the native race, the child of Asia, beckoned the white man on, toward her ancient home in the Orient. -Eva Emery Dye ${ }^{23}$

On July 6, 1905, several fairgoers dressed in what a local newspaper described as "picturesque native costume" stood out in the thousand-strong crowd that gathered at the Lewis and Clark Centennial Exposition in Portland, Oregon. They watched as Susan B. Anthony and other prominent woman suffragists unveiled a statue of the young Shoshone woman, Sacajawea. Sacajawea, the suffragists alleged, “did what many Indian women did," in the nineteenth-century West by "becoming the wives of trappers and traders, revealing the secrets of their country and giving over its trade and resources to the whites, opening the way for a higher civilization." The suffragists enlisted a Native Alaskan man, Charles Cutter, to perform a "patriotic solo" during the ceremony, a gesture that appeared to further affirm Native acquiescence to the U.S. civilizing mission. The legendary Sacajawea created by suffragists represented a memory of nature and human antiquity

\footnotetext{
${ }^{23}$ Eva Emery Dye, quoted in "Statue of Bird Woman Unveiled," Oregonian, July 7, 1905, p. 11; James P. Ronda, Lewis and Clark Among the Indians (Lincoln: University of Nebraska Press, 1984), 256-260; Frederick E. Hoxie and Jay T. Nelson, eds., Lewis \& Clark and the Indian Country: The Native American Perspective (Urbana: University of Illinois Press, 2007). Many spellings, pronunciations, and meanings have been assigned to Sacajawea. This study uses the spelling used by the Exposition and its participants: Sacajawea. Historians have also debated whether Sacajawea is a Shoshoni name meaning "boat launcher" or a Hidatsa name meaning "bird woman," most conclude the latter. A recent collection of essays on the Lewis and Clark expedition from Native American perspectives used the spelling Sekakawea.
} 
that journalists covering the ceremony echoed in their portrayal of Native fairgoers as a part of the scenery. ${ }^{24}$

Interpreted from another angle, the un-staged wearing of Native clothing styles appeared as an act of everyday resistance to the so-called higher civilization.

Acknowledged but dismissed by the mainstream press, the Native presence in Portland, including that of the more assimilated Charles Cutter, destabilized the declaration that Sacajawea's statue would stand for erasure or disappearance when seen "in the City Park, on the trails her people travel no more." By interpreting these episodes of an unscripted Native presence at the Fair as moments of disruption in the imperial narrative, this chapter demonstrates how Native Americans disturbed the suffragists' visions of white civilization through cultural resilience or indifference towards the U.S. imperial regime embodied in the Fair. As the parade and statue scenario suggest, disruptions often involved modern forms of public leisure and labor, and "improper" mixtures of traditional and modern practices that cut against exposition's fixed image of a static, primitive, and vanishing people. $^{25}$

\footnotetext{
${ }^{24}$ Dye quoted in "Statue of Bird Woman Unveiled," Oregonian, July 7, 1905, p. 11; "Statue of Sacajawea Unveiled at Exposition," Olympia Daily Recorder, July 6, 1905, p 1.

25 "Statue of Bird Woman Unveiled," the Oregonian, July 7, 1905, pg. 10 - 11; William L. Lang and Carl Abbott, Two Centuries of Lewis \& Clark: Reflections on the Voyage of Discovery (Portland: Oregon Historical Society Press, 2004), 26; Hoxie and Nelson, Lewis \& Clark and the Indian Country, 129, 156-157. Sacajawea experienced multiple physical and epistemic displacements before and after the expedition. First kidnapped from her Lemhi Shoshone band by Hidatsa raiders in 1800, she then spent several years living amongst the Hidatsa before she and another Shoshone woman were sold as wives to the middle-aged French fur trader Toussaint Charbonneau. Shortly thereafter, Sacajawea, Charbonneau, and their infant son joined the Lewis and Clark expedition as translators. Sacajawea was about seventeen years old in 1805, and already had linguistic and kinship ties to numerous Native American societies throughout what is now Idaho, the Dakotas, and Oregon.
} 
The voluminous records of the Lewis and Clark Exposition reflect the discrepancies of power at the Fair itself to reveal a tense narrative of empire and selfrepresentation. Correspondences, newspaper articles, and speeches about the Fair contain the symbolic and physical forms of violence waged against Native Americans by numerous prominent, upper- and middle-class white women during the 1905 Exposition. From the appropriation of nineteenth-century Native American history, especially the life of Sacajawea, to the use of contemporary Native Americans as specimens of colonial experimentation, the designs of white woman's empire relied upon real and mythic Native Americans. This reliance upon so-called Indians rendered the suffragists' imperial designs visible but also vulnerable to counteractive disruptions and resistance. By interrogating the Native identities presented in the Exposition's literature, speeches, and propaganda, as well as the temporal displacement of Native-American fairgoers from their European-American contemporaries, this chapter highlights the fragile points of empire and its re-stagings as a success narrative in the city. Together this literature and its rhetorical device entailed methods of imperial destruction as well as instances of disruption that occurred within on-the-ground negotiations and conflicts between white suffragists and Native Americans in Portland. 


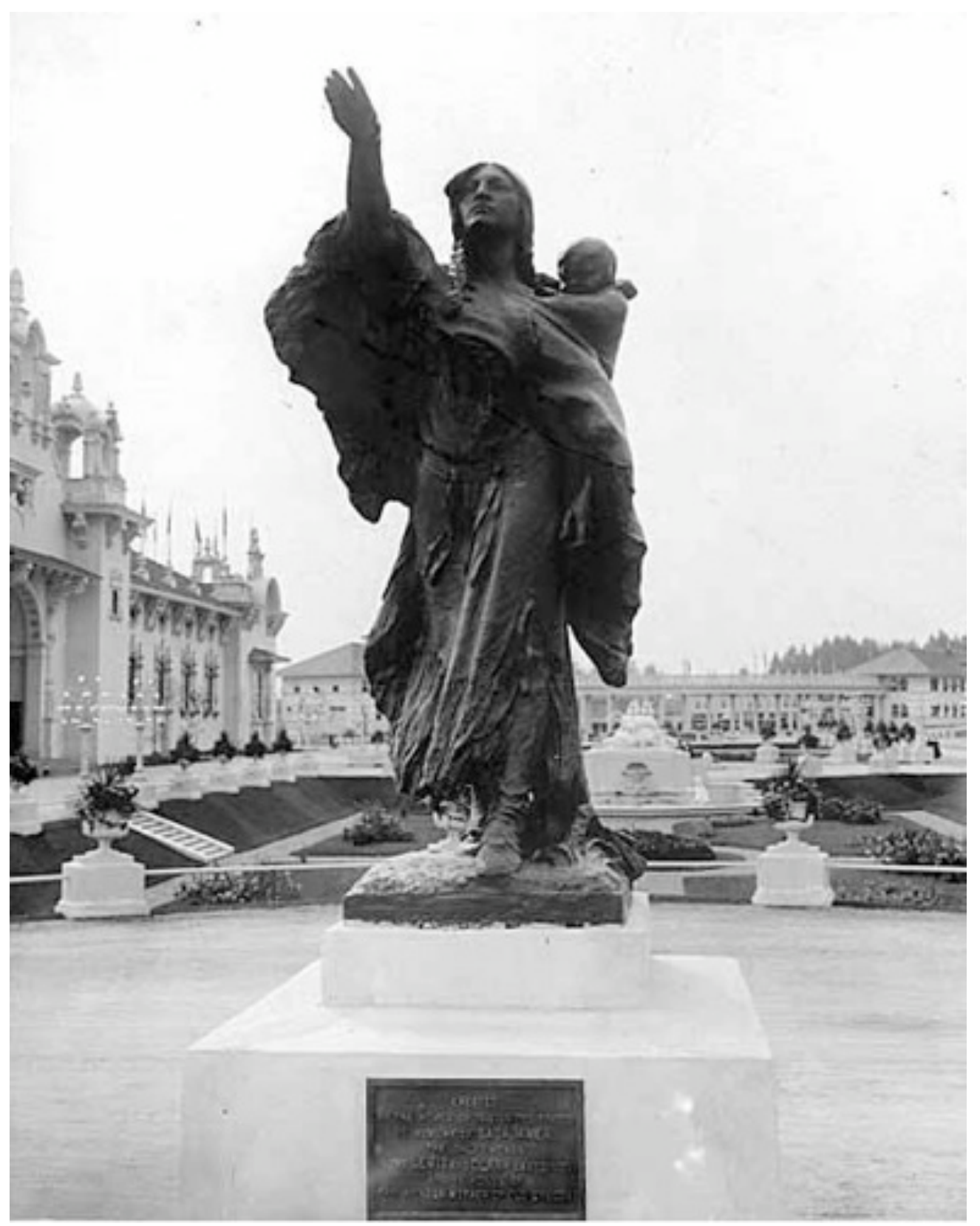

Image 1.1 The Sacajawea Statue, University of Washington Libraries, special collections division, Lewis and Clark Exposition, PH Coll 391, box 1, folder 13. Eva Emery Dye's Sacajawea State Association raised \$7,000 to have the sculpture built. Touted as large-scale regional woman's effort, contributions arrived from Idaho, Washington, Nebraska, Montana, and the Dakotas. Much of the statue's copper from a mine in Montana subsequently named "The Sacajawea." Sculpted by a woman from Colorado, Alice Cooper, Sacajawea stands today in Portland's Washington Park. 


\section{Speeches and a Statue: The Maternal Violence of Conquest}

But Oregon does not forget the pair who blazed the way and mapped her future greatness out - she honors them to-day. In gleaming copper, too, she casts the forest queen of old who guided through the wilderness those men of iron mould. ${ }^{26}$

The exploitation of Sacajawea unfolded in phases during the course of the Lewis and Clark Exposition. Using various visual and textual appropriations of her motherhood, suffragists crafted multiple historical narratives, ancient and modern. By 1905, the Oregon City writer, scholar, and suffragist Eva Emery Dye had already started to construct the Sacajawea legend in her book, The Conquest: The True Story of Lewis and Clark. ${ }^{27}$ Dye's interpretation of the expedition's original journals romanticized Sacajawea largely through the biblical roles of helpmeet and self-sacrificing mother. The Conquest portrayed Sacajawea, the teenaged Shoshone, as a "modest princess ... heroine of the great expedition...Madonna of her race," a depiction echoed in press commentary on the statue. For example, Lillian Gray, a journalist out of Macon, Georgia, understood the exchange of Sacajawea's true Native identity for a mythical one as a redemption from savagery. "As the statue stands," she wrote, "the Bird Woman's pose is that of a Minerva

\footnotetext{
${ }^{26}$ Minna Irving, "The Lewis and Clark Exposition," in Leslie's Weekly: Lewis and Clark Centennial Exposition Issue, June 22, 1905, in Mss 1609, box 123, folder 12.

${ }^{27}$ Eva Emery Dye, The Conquest: The True Story of Lewis and Clark. Chicago: A.C. McClurg \& Company, 1902). For more on the Lewis and Clark Expedition and its subsequent commemorations see Abbott and Lang. Two Centuries of Lewis \& Clark; Donna J. Kessler, The Making of Sacagawea: A Euro-American Legend (Tuscaloosa: The University of Alabama Press, 1996); Hoxie and Nelson, Lewis and Clark and the Indian Country. The journals written by Lewis, Clark, and other corpsmen but nonetheless acknowledged her utility. The men never framed her as a national heroine. Indeed, they described Indian societies as distinct Indian nations. Sacajawea's emergence as a U.S. cultural icon began in the late 1890s as part of a larger, Progressive Era tendency to appropriate Native American identities in part to erase the violence of conquest. Considered the most significant Progressive Era re-interpretation of the journals, Dye's the Conquest led a large number of Western women's social organizations to employ Sacajawea for a variety of causes, including but not limited to suffrage.
} 
or Queen Boadicea....Nobody, of course, knows how Sacajawea really looked, except that all squaws appear alike after they have become slaves and wives. Miss Cooper knew well what the average Indian wife looks like, but chose to present the soul of her splendid subject rather than the body, and she was quite right." ${ }^{, 28}$ Gray joined Dye in a celebration of Sacajawea that simultaneously subordinated and erased Native women, an act of identity theft that mixed ancient and mythic female tropes to relegate Native American women to transitional and ethereal roles, and to feminize an equally mythic national past.

On the stage of the Sacajawea Statue unveiling, suffragists reoriented the nationalist mythology of the nineteenth-century frontier to subtly claim its violence - acts of conquest, settlement, and expansion that had allegedly created a uniquely American character- for white women. Unlike the masculine military aggression associated with the frontiersman, Dye and her fellow suffragists articulated the superiority of feminine imperial power, violence that they did not recognize as such and which they described instead as civilization-work and nation-building. White suffragists also contributed to a broader turn-of-the-century tendency, employed by women and men, to portray imperialism not as a force of military brutality and domination but rather one characterized by benevolence, homesteading, and domesticity. ${ }^{29}$ Through speeches that

\footnotetext{
${ }^{28}$ Eva Emery Dye, The Conquest, 290; Lillian Gray, "Miss Alice Cooper's Statue of Sacajawea," Macon Telegraph, June 5, 1905, pg. 7.

${ }^{29}$ Kristin L. Hoganson, Fighting for American Manhood: How Gender Politics Provoked the Spanish-American and Philippine-American Wars (Yale University Press, 1998), 180 - 199; Patricia Schechter, "Feminist Approaches to Anti-Imperialism: A Case for the Decolonial" (conference paper, American Anti-Imperialism since 1776, University of Oxford, Oxford, UK, April 29 - 30, 2011), 12 - 14; Allison Sneider, Suffragists in an Imperial Age: U.S. Expansion and the Woman Question, 1870 - 1929 (New York: Oxford University Press, 2008), 7 - 8. For a late-nineteenth-century description of benevolent imperialism published in a Portland newspaper, see "Empire and Freedom," Oregonian, December 20, 1898, p. 4
} 
established both racial criteria for civilized womanhood and a historical argument for women's political participation, the suffragists drew the public's attention toward white women's frontier civilization-work. After commending "Indian women" for "opening the way," Dye immediately went on to dismiss Native societies for an alleged lack of gender differentiation, "Women are not by nature explorers and travelers, but where women go, homes can go, families can be reared, towns, cities, and states can be founded. Not until women came could America take any secure hold of Oregon and this great Pacific empire. ${ }^{\prime 30}$ Dye erased Native women's domestic roles as wives and mothers to construct a pre-national, Native West devoid of families, homes, and properly gendered identities. She used these lacks to imagine a civilized, nationalized West secured through the presence of true (white) women. ${ }^{31}$

The suffragists did not disrupt the Exposition's dominant vision of progress, but rather relocated imperial power - and understated forms of colonial violence - to the realm of white, middle-class, feminine domesticity. "With women and wagons, Oregon was taken," Dye announced, "The mother and child took Oregon...not until mothers came was the true seed of a nation planted. And Sacajawea led them all, the dark-eyed princess of the native race, the child of Asia, beckoned the white man on, toward her ancient home in the Orient. Silent she stands, beckoning, beckoning." Dye naturalized

\footnotetext{
${ }^{30}$ Dye quoted in "Statue of Bird Woman Unveiled," the Oregonian, July 7, 1905, p. 11.

${ }^{31}$ For more on gender differentiation as a unit of civilizational measurement see Sneider, Suffragists in an Imperial Age, 13 and Okihiro, Common Ground, 69. By applying a lack of maternal qualities to nonwhite women, Dye also implied her support for contemporary assimilation projects that deemed Native Americans and Filipinos unfit for parenthood and coerced them to send their children to be civilized by white women in colonial institutions. Portrayals of Native American women as oppressed or sexualized joined those that idealized them ancient souls.
} 
U.S. expansionism by reinterpreting western conquest as a woman's project. In her imperial imaginary, Native women provided a primitive maternal instinct but lacked the "true seed" and could not provide authentic motherhood. White pioneer women, especially mothers, took land in order to grow the nation-state. In her ambiguous placement of Sacajawea in both European and Native identities, however, Dye simultaneously opened her speech to an alternative interpretation of Sacajawea as a mother who carried the "true seed." This created a small gap in Dye's imperial design through which Native Americans might stake their own claims to pioneer identity and the development of the West, or, more disruptively, challenge the hypocrisy of democratic imperialism. Through the Oregon Donation Land Act of 1850, U.S. Congress seized Native-American land and offered it in 320-acre plots to "all white male citizens of the United States," and "American half-breeds," framed largely as the sons of white men. Women enhanced men's rewards. In the case of married couples, the law provided that wives could hold an additional 320 -acres in their own names. Although some white men's Native-American wives succeeded in reclaiming tribal lands in their own names, the law privileged Dye's vision of white wives as the new "inheritors" of Sacajawea's land. $^{32}$ In an additional dislocation that rendered Native-American women more foreign in the contemporary West, Dye depicted Sacajawea as silently and willingly surrendering

\footnotetext{
${ }^{32}$ United States Congress, Oregon Donation Land Act, ch. 76, sec. 4 - 5, 9 Stat. 496, 497 (1850); Peggy Pascoe, What Comes Naturally, 96 - 98. Washington Territory was also settled under the Oregon Donation Land Act and many white men married to Indian women made donation land claims in the Native women's homelands. As Pascoe points out, subsequent waves of white settlers preyed upon lands held in the names of Native-American women, resulting in numerous court cases. For more on the appropriation of Native American lands by laws that privileged white married women's property, see Robert Gilmer and Tracy Rizzo, "Chickasaws, Tribal Laws, and the Mississippi Married Women's Property Act of 1839," Journal of Mississippi History 68 (2006): $131-148$.
} 
both the West and Asia to American civilization. Dye crosscut her narrative of gendered conquest with anthropological racial theories to portray a shared primitivity amongst the non-European people of the Pacific Rim. Paradoxically, Dye silenced Sacajawea when she restaged her silent body as "beckoning," despite the fact that her linguistic skills and motherhood had ensured the safe passage of Lewis and Clark through Indian country.

The prominent Oregon suffragist and journalist Abigail Scott Duniway amplified Dye's argument with additional acts of representational violence and spatial dislocations. In her speech, “The Pioneer Mother," given at the Sacajawea ceremony, Duniway portrayed Sacajawea as a noble squaw-drudge similar to but more oppressed than Dye's Indian princess. "Waving back the dark savagery to which she was born, beckoning forward the advancing civilization to which she was wed," Duniway constructed Sacajawea like Dye had, as the first maternal agent of U.S. imperialism, welcoming women like Duniway to the West. Duniway's family traveled to Oregon in the 1850 s to settle, at no cost, on federally appropriated Native land. As a participant in Dye's "women and wagons...mother and child" conquest of Oregon, Duniway's own rise to prominence required Sacajawea's surrender to white civilization. Duniway constructed Sacajawea's racialized difference in more generalized terms than Dye's "Asiatic" framing. Describing the Sacajawea statue as "a historic reminder of a vanished era, when woman carried man on her shoulders - a feminine Atlas," Duniway envisioned Sacajawea as a historical icon who would "perpetuate the memory of those barbarous times when woman carried man upon her back." ${ }^{, 33}$ Characterizing gender oppression as

\footnotetext{
${ }^{33}$ Abigail Scott Duniway, "The Pioneer Mother," reprinted in "First Monument to Indian Woman," Oregon Daily Journal, July 6, 1905, p. 2; Jean M. Ward and Elaine A. Maveety, eds.
} 
barbaric, Duniway appropriated Sacajawea to put the issue of women's social inequality before the public. Like the Asian-Caucasian liminality assigned to Sacajawea by Dye, Duniway's Sacajawea, a marriage of racialized savagery and gendered civility, embodied progress made by white women's frontier work. White women's emphasis on their own disenfranchisement despite a century of progress indicated the continued necessity of women's social reform.

Dye's architecture of a feminized frontier echoed in the speeches and press coverage of the Susan B. Anthony celebration held several days before Sacajawea Day at the Exposition. The narrative of progress presented at Anthony's reception abandoned Native-American identities in favor of what Dye referred to as Sacajawea's "Caucasian future. ${ }^{34}$ These perspectives, now haunted by unnamed Native Americans, remapped the gender and geography of national progress to reframe the American West as the pinnacle of civilization and white women's rights as the next frontier of social advancement. One of the Fair's largest audiences gathered in the Oregon building on July 1, 1905 to see Anthony, the eighty-five-year-old "venerable leader" and "intellectual light" who joined other nationally-renown suffragists to promote suffrage and celebrate female pioneers. ${ }^{35}$

\footnotetext{
'Yours for Liberty': Selections from Abigail Scott Duniway's Suffrage Newspaper (Corvallis: Oregon State University Press, 2000), Duniway worked as a schoolteacher and ran a millinery shop in the $1850 \mathrm{~s}$ and $60 \mathrm{~s}$. She became the primary breadwinner for her family after her husband suffered injuries from a horse and wagon accident. Duniway eventually focused on her journalistic career, which also offered her the means to support her family. She combined her interests in journalism with her devotion to woman's suffrage in 1871 when she established her own newspaper, The New Northwest. Her brother Harvey W. Scott, editor of the Oregonian, was one of the Exposition's primary organizers and the city's most influential civic leaders.

${ }^{34}$ Dye, quoted in "Copper Mine Named for Sacajawea," The Lewis and Clark Journal: The Official Bulletin of the Lewis and Clark Fair 1, no. 2 (February 1904), 26.

35" Ovation Given Miss Anthony, Leader of Equal Suffrage Warmly Greeted at the Exposition," Oregonian, July 1, 1905, p. 11. Suffragists gathered in Portland for the $37^{\text {th }}$ annual National
} 
One featured speaker, Indiana journalist and suffragist Ida Husted Harper, declared, "Eastward the star of woman's empire takes its way. She does not look for the star in the East but for the star in the West. Her sun of political freedom rose not in the East but in the West." Harper recast the Exposition's official slogan "Westward the Course of Empire Takes Its Way" to link the vigor of the suffrage movement with that of national expansionism. In contrast to the 1861 Emanuel Gottlieb Leutze mural by the same title, and which portrayed many white men leading a few white women westward, Harper's "woman's empire" framed progress as social change instigated by white pioneer women and connected their legacy to the contemporary suffrage movement. ${ }^{36}$

Women's Suffrage Convention held at the same time as the exposition which was, like the Fair, the first of its kind on the West Coast. Carrie Chapman Catt, Anna Howard Shaw, Antoinette Brown Blackwell, Lucy Stone Blackwell, Abigail Scott Duniway, among others joined Susan B. Anthony "in the receiving line," at the reception. Anthony's experience in Portland contrasted sharply with her treatment at the 1876 Philadelphia Centennial Exposition where she and Elizabeth Cady Stanton were denied the right to campaign for suffrage on the fairgrounds. ${ }^{36}$ Ida Husted Harper quoted in "Ovation Given Miss Anthony, Leader of Equal Suffrage Warmly Greeted at the Exposition," Oregonian, July 1, 1905, p. 11. For more information on the strength of woman's suffrage in the U.S. West, see Ellen Dubois, "Woman Suffrage: The View From the Pacific," Pacific Historical Review 69, no. 4 (November 2000): 539-551, Jensen, "Revolutions in the Machinery," 342 - 343; Mead, How the Vote Was Won. "Westward the Course of Empire Takes its Way" was engraved on the fair's entrance colonnade and first appeared in a 1726 poem by the Irish philosopher George Berkeley entitled "Verses on the Prospect of Planting Art and Learning in America." 


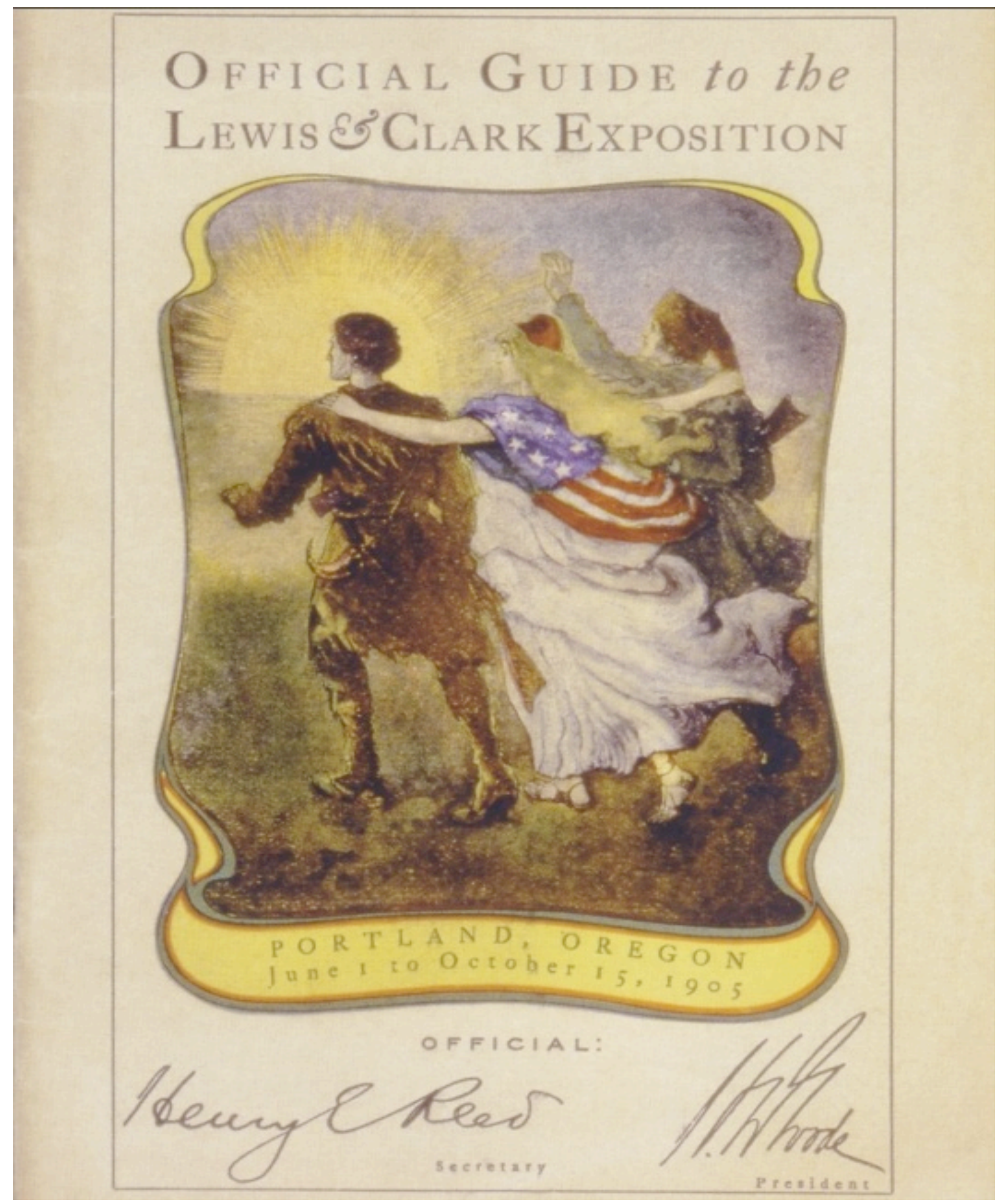

Image 1.2 Lady Progress, Raphael Beck, seal from Official Guide to the Lewis and Clark Exposition, 1903, Exposition Records, Mss 1609, box 98, folder 17. The exposition's official seal depicted Lewis and Clark guided not by Sacagawea but by a mythical white woman in flowing robes. 
The staging of woman's empire and the self-presentation of suffragists at the exposition accented the seemingly inexorable logic of progress, empire, and “civilization," but with distinctly gendered dimensions. By emphasizing the domestic nature of woman's participation at the Fair, the press contained and segregated prominent suffragists to alleviate their disruption of the male-dominated public and political spheres. One journalist deemed the buildings used by suffragists "parlors" wherein women, "thoroughly familiar with the necessary requirements of a hostess and possess all the qualifications," served refreshments and greeted guests. The press minimized the suffragists' disruptive interjection by rendering women's public participation part of the Fair's domestic service. The exposition's official seal also ran counter to the suffragists' vision of women's historical agency. The seal featured a woman who better resembled the identity assigned to Sacajawea, a mythical guide for white civilization; however, it also dislocated white women into a mythology more abstract than that which the suffragists assigned to Sacajawea. The seal presented an ancient goddess-like figure, "Lady Progress," as the guide of gun-wielding Lewis and Clark. It more thoroughly erased real women - white and Native - from the national narrative while maintaining a realistic, historical representation of frontier manhood. Lady Progress wore flowing white robes and rudimentary sandals, and symbolized a primitive femininity even less real than - and lacking the historical agency of - Sacajawea and the Pioneer Mother.

Unlike previous U.S. fairs and exposition, the Portland Lewis and Clark Centennial staged suffragists as national celebrities. The local and national press coverage circumscribed women's success largely through rhetoric that domesticated their 
public participation. Newspapers failed to mention that the Exposition's organizers had officially declined women's request for a Board of Lady Managers and a women's building. ${ }^{37}$ In a sense, women adhered to a design of public domesticity through the construction of a maternalistic pioneer womanhood that seemed to pacify the turbulence of the so-called "New Woman," another label applied to women who questioned gender inequalities and asserted themselves in public forums. Women and the Oregon press alleviated the crossing of gender boundaries by containing their roles as safely domesticated in the service of the state and the national family. ${ }^{38}$ The officially excluded clubwomen nonetheless received ample support from the local press and the exposition's organizers, in part because their activism strengthened the image of Portland as a modern Progressive city, as opposed to a those of a stuffy eastern city with European traditions or a less reproductive New Woman modernity. ${ }^{39}$ Prominent women like Duniway and Dye with complex if unstated agendas - namely potential critiques of the nation-state and its undemocratic contradictions - challenged the criteria for citizenship, in large part, through a reinforcement of the U.S. imperial project. White women's participation in conquest helped to naturalize and pacify U.S. expansionism in the national imaginary by displacing the violence and exclusions undertaken by the state. The Oregonian buttressed

${ }^{37}$ Olsen, "Fair Connections," 175 - 176.

38“"Statue of Sacajawea Unveiled at Exposition," Washington: Olympia Record, July 6, 1905, p. 1; "Ovation Given Miss Anthony, Leader of Equal Suffrage Warmly Greeted at the Exposition," Oregonian, July 1, 1905, p. 11.

${ }^{39}$ For more on New Womanhood and its multiple use and re-configurations, see Patricia A. Schechter, Exploring the Decolonial Imaginary: Four Transnational Lives (New York: Palgrave Macmillan, 2012), 49 - 90; Martha H. Patterson, Beyond the Gibson Girl: Reimagining the American New Woman, 1895 - 1915 (Urbana: University of Illinois Press, 2005); Patterson, The American New Woman Revisited: A Reader, 1894 - 1930 (New Brunswick, NJ: Rutgers University Press, 2008). 
the suffragists' correlation between national progress and woman's social equality by revering the older generation of suffragists. Seventy-year-old Duniway received press coverage describing her as an embodiment of "the qualities of the pioneer wives and mothers who had an equal share in the settlement of Old Oregon. ${ }^{40}$ Assigning women like Duniway the status of pioneers elided the conquest of Native-American land and people with the acquisition of citizenship and the inheritance of land by white women.

Duniway also adhered to the international framework of a Pacific woman's empire. On October 6, 1905 a large crowd gathered at the Fair to recognize Duniway as "one of the greatest living pioneers of this state." ${ }^{41}$ Duniway addressed the audience with a speech on the expanded scope of the local suffrage campaign. In her address, she warned "the men of Oregon" that they had an international audience of women watching them and relying on their "moral chivalry and patriotic valor" at the ballot boxes. "Even in India the women of the zenanas are watching the outcome of the pending battle of the ballots in this historic state of Oregon. The more enlightened women of the Hawaiian Isles and the Philippines and Japan are also watching and waiting for the glad tidings of citizenship that await the women of Oregon," Duniway declared with a universalizing flourish that positioned enfranchisement as a ubiquitous desire amongst the "enlightened" women of the Pacific Rim. To Duniway, the Oregon suffrage campaign surpassed the Lewis and Clark expedition in terms of "spiritual power and enlightened importance." She relegated the expedition to a plot device that "foreshadowed this historic day in

\footnotetext{
40 "Ovation Given Miss Anthony, Leader of Equal Suffrage Warmly Greeted at the Exposition," Oregonian, July 1, 1905, p. 11.

41 “Abigail Scott Duniway Day," Woman's Tribune, October 28, 1905; "Statue of Sacajawea Unveiled at Exposition," Washington: Olympia Record, July 6, 1905, p. 1.
} 
honor of the pioneer women of old Oregon, of whom your humble, but pleased and happy respondent, is but one. ${ }^{42}$ Duniway interpreted Oregon women's activism as having a civilizing influence on American men, and as providing as an instructive model for women's rights movements in Asia and the Pacific.

Duniway participated in a broader effort amongst white American suffragists to universalize the nature of the U.S. movement. Framing suffrage as part of the civilization package offered by U.S. expansionism, white suffragists also lobbied for the enfranchisement of Filipina, Native-American, and Native- Hawaiian women as a means to protect themselves against uncivilized men. As Allison Sneider has explained, the suffragists' demand "that Congress enfranchise women in new U.S. colonial possessions served to legitimate the U.S. imperial project." ${ }^{, 43}$ Duniway regarded the "more enlightened" among Native and Asian women as interested in enfranchisement. The suffragists' inclusive internationalist and universalizing rhetoric obscured the Orientalist and racial ideologies used to justify imperialism and discriminatory citizenship and marriage laws. The boundaries of women's citizenship appeared more blatantly when suffrage passed in Oregon. The 1912 law enfranchised "citizen" women, which only included European-American women and Native women legally married to U.S. citizens or who ceded their land to the federal government. Noncompliant Native women and men

\footnotetext{
42 “Invite to Honour Mrs. Duniway," Oregonian, October 7, 1905, p. 11.

${ }^{43}$ Suffragists argued that as the more civilized members of any given society, all women needed protection against promiscuous and barbarous men, including U.S. soldiers. In 1902, commissioner to the Philippines, William Howard Taft saw the enfranchisement of Filipina women as more necessary than that of Filipino men in transitionining from military to civil governance. Sneider, Suffragists in an Imperial Age, 123 - 124. For more on the exclusive nature of European and U.S. internationalist women's movements see Leila J. Rupp, "Constructing Internationalism: The Case of Transnational Women's Organizations, 1888 - 1945," American Historical Review 99, no. 5 (Dec., 1994): 1571 - 1600.
} 
could not vote until the passage of the federal Indian citizenship act in 1924. First generation Asian-American immigrants, women and men, remained disenfranchised and ineligible for citizenship until $1952 .^{44}$

In their speeches on pioneer womanhood, Duniway and Dye envisioned Native and Asian women as beckoning for and "enlightened" enough for suffrage, but, in the end, excluded Native women who did not adhere to European-American civilizational criteria. In their commentary, suffragists and journalists identified characteristics of the pioneer past still alive in the modern West. This ideological maneuver can also be interpreted as permitting room for the persistence of a Native-American legacy despite the alleged closure of the frontier. The Anglo-American narrative of progress fluctuated between the historic white pioneer and the modern white citizen, and cited projects of racial uplift and Christian conversion amongst Native Americans as markers of white civilizational authority. Racialized hierarchies limited the pioneer past to a EuropeanAmerican perspective that obscured Native and Asian Oregonians as well as their impact on industry, commerce, and culture in the West. To accomplish this (dis)appearing act, suffragists conscripted real Native Americans to provide visual evidence of women's civilization-work at the Fair.

\footnotetext{
${ }^{44}$ Jensen, "Revolutions in the Machinery," 343 - 344, 359; Wong, Sweet Cakes, Long Journey, 30, 120. The 1887 Dawes Act allotted citizenship to Native Americans who participated in the federal allotment system. An additional 1907 law regulated all women's rights by requiring that a female U.S. citizen must take the nationality of her husband. If she married a non-citizen male, she lost her U.S. citizenship status and its privileges. The Married Women's Independent Nationality Act, also known as the Cable Act, created in 1922 initiated a recovery of married women's personal citizenship rights that continued until the 1930s.
} 


\section{Performative Disruptions}

As the Sacajawea Statue ceremony speeches suggest, suffragists relied on appropriations of Native American figures, history, and bodies to construct and legitimize their own social identities and political arguments. Eva Emery Dye enlisted real Native Americans to attend the fair as living examples of progress made in the time since Sacajawea surrendered the West. Exhibiting one Shoshone man as "a sample of Sacajawea's people" and another as "a psychologic study" for artists and sculptors to "look at," Dye added a performative aspect to the presentation of woman's empire at the exposition. ${ }^{45}$ In addition to Dye's individual recruits, European-American scholars and federal agents created exhibits that framed real Native Americans as the objects of civilization-work and anthropological science. The federal Indian exhibit calculated Native-American progress through displays of "industrial and literary training given pupils in the Indian schools." It purported to show their ability "to take up the pursuits of our own race."46 To prevent the theoretical self-fulfillment - and thus the end - of the civilizing project itself, reformers persistently assigned Native Americans a liminal status, in-between civilization and savagery, rather than that of a completed product of the civilizing mission, which would render reform work obsolete. Exhibits framed Native Americans as people in transition away from their traditional cultures into the modern

\footnotetext{
${ }^{45}$ Eva Emery Dye to Henry W. Goode, June 30, 1905 and Dye to Goode, September 11, 1905, both in Mss 1609, box 9, folder 11.

${ }^{46}$ Edwin L. Chalcraft in Francis E. Leupp, "Report of the Commissioner of Indian Affairs: The Indian Exhibit at the Portland Exhibition," Annual Reports of the Department of the Interior, Indian Affairs, Part I (Washington, D.C.: United States Office of the Commissioner of Indian Affairs, 1905), 56 http://content.lib.washington.edu/cdm4/document.php?CISOROOT $=/$ lctext $\&$ CISOPTR $=1361 \& \mathrm{R}$ $\underline{\mathrm{EC}}=14$.
} 
work force, namely as manual, agricultural, and domestic laborers. The Fair's reliance upon Native Americans as exhibits simultaneously opened the public space to on-theground Native-American experiences and appearances that contradicted the meanings imposed by the exhibits. People exceeded and, at times, transgressed their scripts and frames in small performances often subdued in the local press.

Suffragists and federal agents dislocated real mothers when they enlisted institutionalized Native-American children to perform as assimilated, industrious students reared not by biological parents but by benevolent, civilizing agents of the state. Children isolated from their Native parents and societies in Salem, Oregon's Chemawa Indian Training School traveled to Portland on multiple occasions to participate in exhibits, parades, and group tours at the exposition. Long before the fair, Abigail Scott Duniway visited the school and described the violent familial disruption required to "civilize" Native children in her suffrage newspaper The New Northwest. Duniway wrote, "we believe it possible to engraft the young of any tribe upon our civilization whenever, as in this case, the tap roots are cut that formerly connected them with the associations of their kind. We have great faith in this experiment. ${ }^{, 47}$ To return briefly to the Sacajawea Day

\footnotetext{
${ }^{47}$ Abigail Scott Duniway, Duniway, "Visit to the Indian School at Forest Grove," The New Northwest, September 2, 1880, in Jean M. Ward and Elaine A. Maveety, eds., 'Yours for Liberty': Selections from Abigail Scott Duniway's Suffrage Newspaper (Corvallis: Oregon State University Press, 2000), 196. Duniway visited the school in 1880 at its original location in Forest Grove, Oregon before it was moved to Salem and named Chemawa. For more on white women's destruction of Native-American families, see Margaret Jacobs, "Breaking and Remaking Families: The Fostering and Adoption of Native American Children in Non-Native Families in the American West, 1880-1940," in David Wallace Adams, Crista DeLuzio, eds., 19 - 46, On the Borders of Love and Power: Families and Kinship in the Intercultural American Southwest (Berkeley: University of California Press, 2012) and Cathleen D. Cahill, Federal Fathers and Mothers: A Social History of the United States Indian Service, 1869 - 1933 (Chapel Hill: University of North Carolina Press, 2011).
} 
parade as a depiction of Duniway's social experiment highlights additional meanings behind the spectacle. Almost two hundred Chemawa school boys dressed in smart uniforms "showed their careful military training" as they marched behind the suffragists. In another twist of identity appropriation, hundreds of white men dressed in clothing evocative of Native American warriors joined the boys and carriage-drawn suffragists. The parade featured white mimicry of Native adult roles and transplanted Native youth. Suffragists and the white Red Men, members of the middle-class fraternal society the Improved Order of Red Men, scripted a scene that depicted successfully severed NativeAmerican "tap roots," cut by the separation of Native-American parents from their children. ${ }^{48}$

Suffragists, Indian agents, and local officials expected Native-American children to perform, through movements and clothing, their liminal position in the national family. "Indian Boys are in Line" the Oregonian announced, and in the same article described the boys as "brothers" of the white Red Men. Chemawa school children received free entry to the exposition, but attended in far smaller groups than Portland's Catholic and public school children. ${ }^{49}$ Native-American children could essentially observe as tourists and be observed as specimens at the federal government's Indian exhibit, but were denied the de-militarized romping play of free children. The exhibit's creator and superintendent

\footnotetext{
48 "Red Men March Through Streets: Feature of the Procession is the Float Bearing Sacajawea. Indian Boys are in Line," Oregonian, July 7, 1905, p. 10. The Red Men were members of the Improved Order of Red Men, a national fraternal organization with local chapters throughout the Northwest.

${ }^{49}$ Theodore Hardee (assistant to the president) to Mr. F. B. Davison (chief of admissions), October 6, 1905, Mss 1609, box 22, folder 4; Hardee to Davidson, October 10, 1905, in ibid. Hardee expected 1,500 to 1,600 Catholic school teachers and students to attend the fair on October 12, 1905 whereas the Chemawa pupils attended "in bunches of twenty-five or more at various times" and entered "through a special gate."
} 
of the Chemawa school, Edwin L. Chalcraft described it as "the first exhibition of Indian work made on the Pacific coast" and saw the Fair as an opportunity for "examining the character of the training given pupils in the Government Indian schools." Housed on Government Island alongside displays of the Philippines, Hawaii, Puerto Rico, and Alaska, the Indian exhibit portrayed Native Americans as the first recipients of U.S. civilizing mission and united them with Filipinos and Native Hawaiians and Alaskans as wards of the state. The exhibit purported to show "their ability to take up the pursuits of our own race," and featured "a few articles representing native arts and crafts made by Indian pupils," a ghostly echo of a lost cultural identity. ${ }^{50}$ Chalcraft's exhibit portrayed institutionalized Native-American children not as preparing for eventual tribal independence but rather for working-class labor and, to some extent, U.S. citizenship. As Allison Sneider has observed after 1871 the extension of citizenship to Native Americans who abandoned their tribal affiliations and privatized their property dissolved Native sovereignty through systemic expropriations of land and identity. This additional method of destroying tap roots, "turning Indians into citizens," Sneider argued, helped alleviate “the lingering ambiguities over Indians' residual independence within the United States that frontier violence made so visible. ${ }^{, 51}$ At the exposition, displaying Native Americans as fit for citizenship simultaneously highlighted the fitness of their federally appointed

\footnotetext{
50“"Indian Work Exhibit for Lewis and Clark Exposition, Progress of a Century," Oregonian, December 28, 1904, p. 5; Chalcraft, "Report of the Commissioner of Indian Affairs," 57. ${ }^{51}$ Sneider, Suffragists in an Imperial Age, 62 - 63. By 1905 the U.S. military had suppressed Native-American resistance to the extent that frontier warfare no longer posed a serious threat to national expansion. As a result, the ideologies, methods, and representations of U.S. conquest shifted towards "creating citizen Indians," which harbored a potentially more devastating threat to Native cultures and sovereignty. Sneider aptly identified "granting Indian citizenship" as a means "to wipe out the Indian far more effectively than wars along the border."
} 
white mothers and fathers whose public work as missionaries, teachers, and scholars endeavored to turn savages into Christian citizens.

In relying upon Native-American children in multiple observational positions - as performers, spectators, students, and inmates - white civilizing agents unwittingly created room for dissenting Native-American perspectives. Two Native-American students demonstrated their dissatisfaction with the civilizing mission and an interest in mobility and urban life when they escaped from the Chemawa Indian School and journeyed to Portland. From the sidelines of the Sacajawea Day parade, the boys, Oscar Boyd and Charles Billideaux, watched as their schoolmates marched with the woman's suffragists. Their disruption, enacted by the juxtaposition of their appearance institutionalized but un-chaperoned and disorderly - with that of their disciplined classmates, exposed a fissure in the civilizing mission. Portland police officers arrested the boys and returned them to the school, and the press patched over their disruption as a sign of eagerness to "attend the celebration of Redmen and see the ceremonies attendant upon the unveiling of the Sacajawea monument" rather than as a protest against their institutionalization. ${ }^{52}$

Given the intimate - domestic, psychological, spiritual - domains of earlytwentieth-century women's imperialism, many performative disruptions of the citizenIndian design at the Portland exposition manifested in behaviors and appearances that actually subverted white women's moral authority. Dress, hairstyles, and rituals deemed inappropriate by Christian missionaries deterred from the legitimizing representations of

\footnotetext{
52“"Indian Boys Run Away,” Oregonian, July 7, 1905, p. 16.
} 
the controlled school children and the bronzed, unmoving Sacajawea statue. The official organizers of the Lewis and Clark Exposition sanctioned some of the appearances that contradicted the suffragists' portrayals of civilizational progress. Out of a desire to offer fairgoers live spectacles of Native Americans whom they considered "curious" and "characteristic of savage life," many traditionally dressed Native Americans performed in the Exposition's exhibits. ${ }^{53}$ In spectacles that simulated frontier warfare, in tepees, totem poles, and curio shops on the fairgrounds, and in canoe and horse races on Indian Field Day, the Exposition inadvertently featured a still thriving Native-American West despite rhetoric of its disappearance. Representations of Native Americans that sought to suspend them in anthropological objectivity or in a static, vanishing primitiveness singly failed. At the conference on Indian affairs, one school administrator allowed for certain performances of traditional Native-American crafts and music as a means "for conserving, so far as is possible, that which is most worthy of preservation in this vanishing race. ${ }^{, 54}$ Cultural preservation guised and pacified the primary goal of Indian institutions; for the most part, the conference attendants discussed cultural destruction and white ownership of Native American identity. Assistant superintendent of Chemawa, W. P. Campbell, alleged that through "changing the dress of our Indians, environment, more[s]" the "Indian worker" instilled a desire to "labor to obtain a livelihood" in the Native-American child. Campbell further designated cultural and racial criteria for

\footnotetext{
${ }^{53}$ Oscar Huber, "Report by Director of Works," The Lewis and Clark Journal 1, no. 1 (January 1904), 14.

${ }^{54}$ Harold A. Loring, "Native Indian Music," in "Appendix: Briefs of Proceedings, Papers, and Discussions at Institutes, Pacific Coast Institute, Portland, Oreg., August 21 - 26, 1905," Annual Reports of the Department of the Interior (Washington, D.C.: United States Office of the Commissioner of Indian Affairs, 1906), 423.
} 
"work," claiming that the Indian "can not work in the blanket, the blanket is discarded."55 The performance of "civilized" Indianness in the federal Indian exhibit upheld a vision of Native children's capacity to "assimilate the 'book knowledge' as well as the hand drill of the white race" once removed from the Native parents, an assessment that reflected well on their white teachers. ${ }^{56}$

When blanketed Indians attended the Fair as consumers and paid performers, they exhibited fluency and competence in modern consumerist and labor practices while still maintaining non-European dress, language, and economies. ${ }^{57}$ Their apparent blend of the exposition's dichotomies: civilized white modernity, savage Native antiquity led white observers to create new strategies and categories to ensure the maintenance of national and colonial authority. Painting Native-American consumers into the fair's "picturesque" aesthetic positioned fairgoers as artifacts and denied their very un-vanished presence in the city. Signs of Native modernity provoked anxiety, and assigning modern Native Americans the aesthetic of quaintness rendered their presence less threatening. When a group of Nez Perce Indians rode a motorboat at the fair, the Oregonian recovered their disruptive blend of tradition and modernity by describing the boat ride as part of the

\footnotetext{
${ }^{55}$ W. P. Campbell, "The Indian of To-day," in ibid, 421.

${ }^{56}$ C. H. McIsaac, "U.S. Government Exhibits," The Lewis and Clark Journal 2, no. 6 (December 1904), 15.

${ }^{57}$ Nicolas G. Rosenthal, Reimagining Indian Country: Native American Migration \& Identity in Twentieth-Century Los Angeles (Chapel Hill: University of North Carolina Press, 2012), 33-37; Paige Sylvia Raibmon, Authentic Indians: Episodes of Encounter from the Late NineteenthCentury Northwest Coast (Durham: Duke University Press, 2005), 35-49; Raibmon, "Theatres of Contact: The Kwakwaka'wakw Meet Colonialism in British Columbia at the Chicago World's Fair," Canadian Historical Review 81, no. 2 (2000): 157-190; Sam Maddra, "American Indians in Buffalo Bill's Wild West," in Blanchard, Pascal, et al., eds., Human Zoos: Science and Spectacle in the Age of Colonial Empires (Liverpool: Liverpool University Press, 2008), 134141.
} 
exposition's attractions, remarking that the band of "living Indian warriors...did not ride their canoes, as one might expect, but in an auto boat." To render participation in modern consumption an atypical behavior for primitive people, the journalist emphasized their "strange and yet very picturesque" characteristics. "The 12 sturdy members of the tribes, clad in all the colors and beads that only the Indians know how to combine, step into the fastest passenger auto boat on the river...their pleasure could easily be seen by the glint of their eyes. But when the engineer turned on full power...their expressions of approval and satisfaction were changed to yells and grunts. ${ }^{358}$ The unintended - and disruptive performance of the Nez Perce boat-riders suggested modernity could be accessed without the religious, linguistic, and lifestyle changes required of the Chemawa students. Allegations of Native fear and unintelligibility- "yells and grunts" - when faced with white mechanical and technological mastery adhered to a racialized hierarchy of competence with modernity that compensated for their mixture of traditional and contemporary practices. ${ }^{59}$

Scripted and everyday appearances of unassimilated Native Americans suggested a lack of appeal for European modernity and challenged its inevitability. Exhibits of "blanketed" Indians making baskets, practicing archery and horsemanship, and in sham frontier battles allowed Native Americans wearing the "picturesque native costume" to perform labor and rituals condemned by missionaries and U.S. federal Indian agents on Reservations and in institutions. As historians have shown, Native-American exhibits often used dress and material objects that were actually inauthentic to the tribes on

\footnotetext{
58 "Noted Indian Here Takes Ride in a Speedy Auto Boat," Oregonian, August 21, 1905, p. 8.

${ }^{59}$ McIsaac, "U.S. Government Exhibits," 15.
} 
display, but had an aura of genuine Indian-ness to white audiences. ${ }^{60}$ For example, the organizers of the Portland Exposition recruited hundreds of Pacific Northwestern Umatilla Indians to play Lakota and Sioux characters in a reenactment of the battle of Little Bighorn. ${ }^{61}$ The blend of modern performance with real and contrived NativeAmerican traditions additionally sparked protest and debate, most notably amongst Oregon missionaries and suffragists. Rather than thoroughly primitive or modern, the range of Native-American behaviors produced a mixed image of the Native West and marked the tensions within the imperial progress narrative staked out by the Fair's organizers. White women social activists seemed particularly affronted by the potential threat this ambiguity posed to their representation of a contemporary Native West largely reformed by white women's civilization-work. The appearances of unassimilated Native Americans in the suffragists' parlors at the Fair reflected poorly on them as mothers and civilizers of a savage race.

Planned portrayals of Native Americans as obedient wards of the state came undone in a number of ways at the Fair. Both by choice and at the request of exposition agents, Native Americans appeared in traditional dress and performed rituals and dances that Reservation and Indian school agents were simultaneously attempting to suppress. Eva Emery Dye's correspondence with missionary Kate C. McBeth and the exposition's President Henry W. Goode, reveals the anxieties provoked by Native-American transgressions of their assigned characteristic of childlike civility. McBeth reported to

\footnotetext{
${ }^{60}$ Raibmon, Authentic Indians, 23-25, 54-62; Maddra, “American Indians in Buffalo Bill's Wild West," 136-137.

61“Will Rehearse Massacre," Wilkes-Barre Times (Penn.), July 31, 1905, p. 5. "Custer Massacre Reproduced at Portland Exposition," Evening News (San Jose, Calif.), August 10, 1905, p. 1.
} 
Dye from her Presbyterian Mission in Lapwai, Idaho where she ran a school for Nez Perce women, "There is much talk among the Nez Perce about the Portland Fair since some parties have been here engaging our wild, long haired ones to go. Of course they will be paid to go through their dances and heathenism. I regret this part of the Fair, it will be demoralizing to all the Western tribes."

McBeth found the promotion of customs and practices she sought to sequester deplorable and contrary to her efforts on the Mission. The display of "wild, long haired ones" represented a lifestyle she had tried to eliminate through her missionary work since the 1870s. "We do not have many such dances but we do have lots of the finest looking Citizen Christians," McBeth wrote, suggesting that the Citizen Christians go to the Fair instead, as moralizing representatives of progress. Expressing her relationship with the Nez Perces in terms of ownership and beauty, McBeth recommended sending "our respectable Indians," Nez Perces like "Kip-ka-pel-i-kan...one of the fine looking ones.",62 She told Dye of individual Nez Perce who displayed appearances appropriate for the Fair. Her letter expressed ownership over their identities and indicated the personal investment she had in the display of Native Americans at the Exposition.

Eva Emery Dye agreed with McBeth and responded, "surely civilized Indians ought to be given precedence over wild unreclaimed ones. Don't fail to let me see you and Kil-ka-pel-i-kan when you come.” Dye articulated her authority over Native Americans in terms of ownership and the inevitability of progress. She compensated for her lack of power over "wild, long haired ones" by denying them legitimate claim over

\footnotetext{
${ }^{62}$ Kate C. McBeth to Eva Emery Dye, Feb. 2, 1905, Mss 1609, box 9, folder 11.
} 
their life choices. Describing unassimilated Nez Perces as "unreclaimed," Dye offset their resistance in terms of linear progress: unfinished projects of the civilizing mission. Dye forwarded McBeth's letter along to President Goode accompanied by a description of McBeth as "the famous missionary among the Nez Perces...the greatest living authority on their language, history." She wrote to McBeth her opinion that "civilized Indians should have a place of honor.... To show the civilized grandson [Kipkapelikan] of that famous chief ought to be an evidence of progress. ${ }^{, 63}$ Practices deemed heathen were a regular source of conflict between Nez Perces and missionaries like McBeth, as well as amongst the Nez Perces who lived on and visited the missions, and between the McBeth and her missionary sister. ${ }^{64}$ By 1905 , McBeth had spent nearly three decades trying to eliminate Native appearances in public and hoped to highlight her success stories at the exposition rather than expose the weaknesses of the civilizing mission. In other instances, however, where Native practices could be construed as appropriate, McBeth profited from traditional Native industries. In 1891, for example, McBeth used funds raised by the sale of "articles of Indian woman's manufacture," to purchase new seats for the Mission's church. ${ }^{65}$

\footnotetext{
${ }^{63}$ Dye to McBeth, Feb. 4, 1905, in ibid.

${ }^{64}$ Kate's sister Sue McBeth, also a missionary to the Nez Perce, did not agree with Kate that unassimilated Nez Perce should be allowed to enroll in the mission schools. Sue and Kate's correspondences with Reverend John C. Lowrie reveal her frustrations with the women of Kate's school who maintained Nez Perce traditions despite instruction - and competence - in Christianity and European-American domestic science. Kate C. McBeth to Rev. John C. Lowrie, March 31, 1884, transcribed in The American Indian Correspondence: The Presbyterian Historical Society Collection of Missionaries; Letters, 1833 - 1893, University of Idaho Library microfilm collection; Sue McBeth to John Lowrie, July 21, 1884, in ibid.

${ }^{65}$ Kate C. McBeth to Mrs. Maxwell, July 20, 1891, in ibid.
} 
Eva Emery Dye appeared much more comfortable dealing with unassimilated Native Americans when it came to conducting her professional work as historian of the colonial past. In interviews conducted with Native-American women, Dye applied the same methods of epistemic violence used to simultaneously erase and commemorate Sacajawea. Dye contradicted her own relegation of Native-American cultural intercessors like Sacajawea to the past. She relied upon twentieth-century Sacajawea figures, like the younger, unidentified Walla Walla Indian interpreter and translator featured in the photograph below whose linguistic skills ensured that Dye would get her "true" story of conquest. Dye described the other featured woman, Sechowa, also a Walla Walla Indian, as an eyewitness to the Lewis and Clark expedition. Standing and observing, pen cocked and clothed in the elaborate apparel of bourgeois womanhood, the photograph presents a visual contrast between Dye's literary modern self and the source of her scholarship, the oral tradition of the Native. 


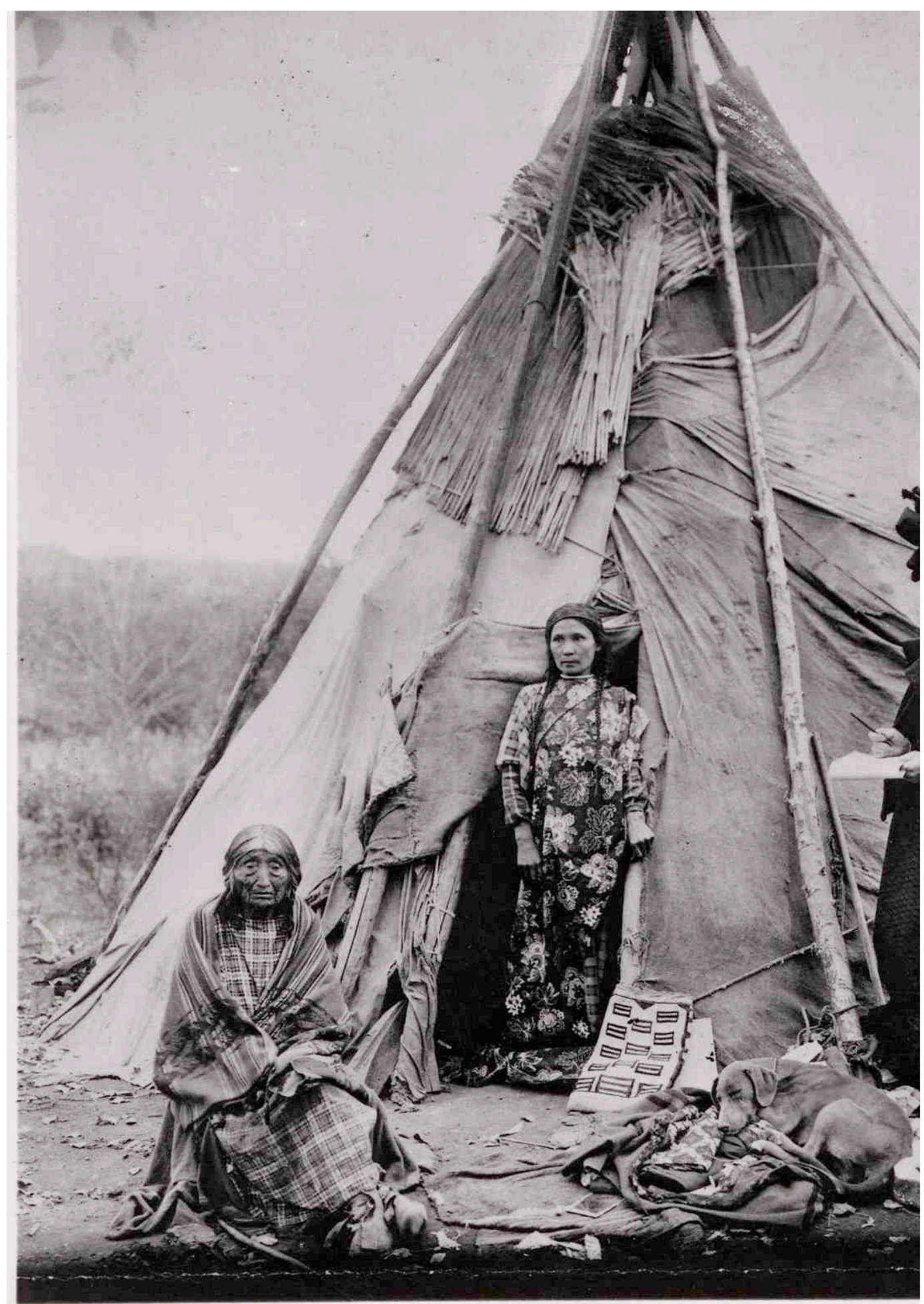

Image 1.3. Eva Emery Dye with Walla Walla Women. Dye Family Photographs Collection, Org. Lot 1017, box 1, folder 7, OHS. 
The city of Portland put forward a message of successful civilization. McBeth and Dye developed feminized avenues into the regulation of colonial spaces, such as beauty, morality, dress, childcare, and health, through which they measured civilizational status. They hoped to replace "wild" Indians with "the handsomest civilized Indians...noble looking men" in order to redirect the fair's narrative of progress to include and valorize women's civilization-work. ${ }^{66}$ This operation of maternalism transplanted domestic concerns, those traditionally assigned to mothers and wives, onto the public domain, resulting in new opportunities for physical and professional mobility amongst middleclass women. Missionaries and scholars of Native American history like Eva Emery Dye and Kate McBeth depended on Native Americans as targets of their reform, but also as primary sources for their scholarly work. Both women published books on nineteenthcentury Native-European encounters in the West and interviewed Oregon's Native Americans who retold their stories, adding an aura of historical accuracy to the literary appropriations. ${ }^{67}$ Reformers and missionaries sought to diminish Native-American traditions, cultural practices, and mobility by confining them to reservations and federal institutions. The Exposition offered Native Americans employment and mobility beyond the hardships and restrictions of reservation life.

\footnotetext{
${ }^{66}$ Dye to McBeth, Feb. 4, 1905, Mss 1609, box 9, folder 11.

${ }^{67}$ Kate C. McBeth, The Nez Perces Since Lewis and Clark (New York: Fleming H. Revell Company, 1908).
} 


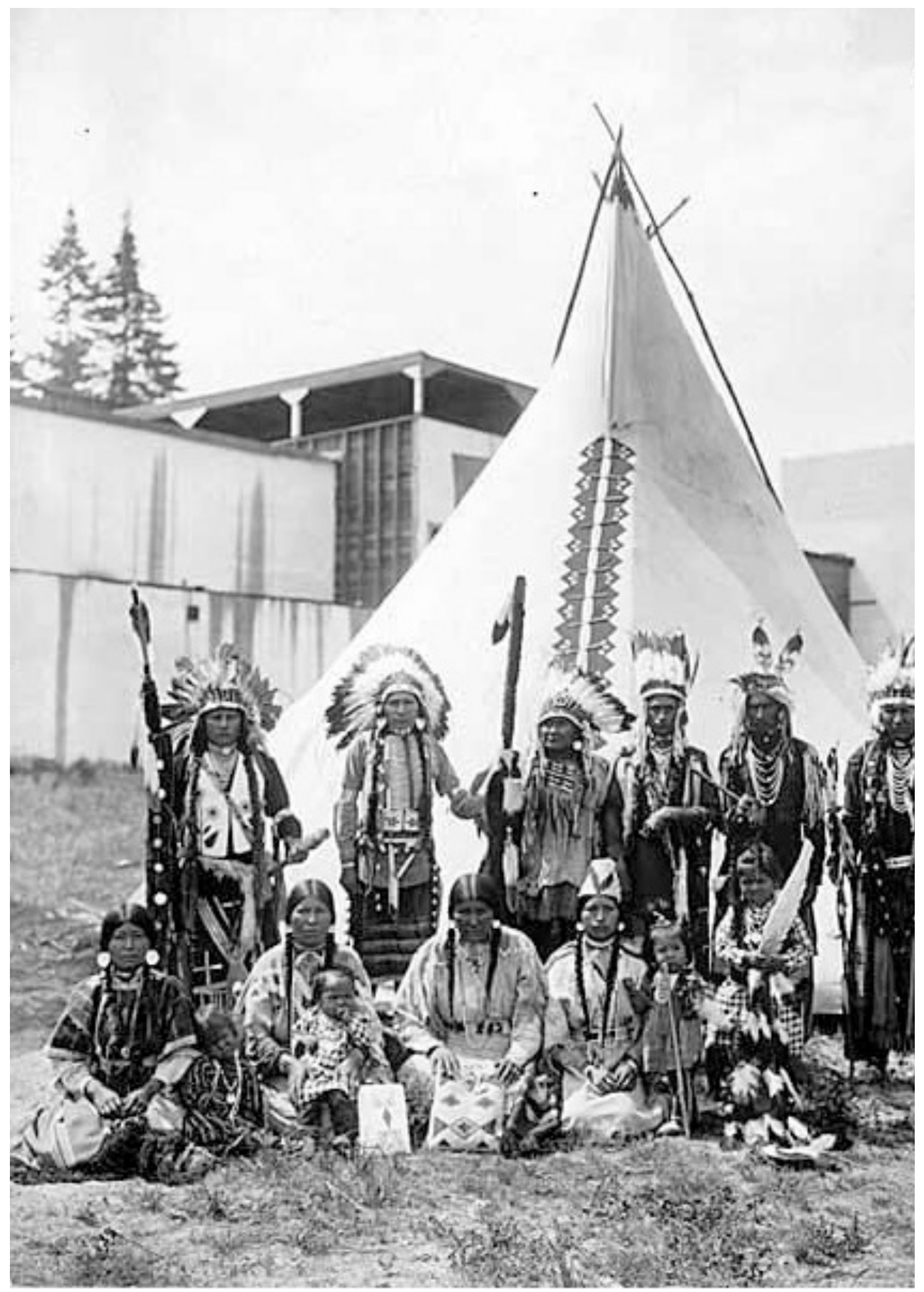

Image 1.4 The Indian Village, University of Washington Libraries, Lewis and Clark Exposition Records, PH Coll 391, box 1, folder 15. 
Dye and McBeth failed to prevent what they regarded as heathenism from materializing in performances throughout the Exposition, but other performances established a conflicting vision of Native-American modernity that both women worked to avoid confronting at the Fair. On a regular basis Native American performers disrupted their desire to spotlight Citizen Christians. Men from regional chapters of the all-white Elks fraternal organization recruited Native-American men from Oregon reservations to perform in the Elks parade on August 16, 1905 at the Fair. Members of the order dressed as frontiersmen and pantomimed being "scalped by the innumerable Indians" who "stalk[ed] through the streets of Portland in war paint and feather, unheedful of the crowding of civilization." 68 An example of Richard White's "inverted conquest," the Elks parade depicted an attack instigated by Indians in order to victimize the colonizer and frame his violence as noble retaliation against savagery. ${ }^{69}$ Where white men of the IORM and the Elks bolstered their own gendered identities and justified the violence of conquest through their control over both Native and white frontier masculinity, women like Dye and McBeth protested these performances in favor of exhibiting Native Americans whose appearances conveyed a century of progress led by white women. In most Fair settings and exhibits, several layers of European-American mediation obscured the perspectives of the Native-American performers to the extent of nearly erasing them from the historical record. In the private correspondences of reformers and in press reports, however, indications that Native Americans expressed perspectives and enacted

\footnotetext{
68“"Elks Plan a Big Day, Indians will Form Feature of Parade,” Oregonian, July 25, 1905, p.10. ${ }^{69}$ Richard White, "Frederick Jackson Turner and Buffalo Bill," in The Frontier in American Culture: An Exhibition at the Newberry Library, August 26, 1994 - January 7, 1995 (Berkeley, 1994), 27.
} 
transformations of Native identity that destabilized the exposition's dominant narrative appeared.

Numerous, mostly unidentified, Native-American women made appearances in exposition's retail outlets that featured over 2,600 Native-American baskets in addition to over 6,000 other Native-American products described as "curios" and "relics." Sold at the exposition by white "lovers and students of the esthetic and of primitive man," EuropeanAmerican vendors catered to a desire for civilized but exotic consumption by separating Native Americans from the products of their labor. Although vendors sold baskets made by contemporary Native American women to modern consumers, commentators classified the items as artifacts from disappearing cultures to be consumed by "relichunters and art students., ${ }^{, 70}$ White vendors largely upheld and reinforced the Fair's other designs by selling Native-American products as artifacts of a vanished past, and hid most economic transactions between Native producers and white collectors from the public view. Like the mixture of unstable designs and appropriations carried out through performances of Indian-ness - by Native and white men - and through Native dress, when Native craftsmen did appear alongside their products at the exposition, they were deemed specimens of anthropological science rather than laborers.

Displacements of Native and, in general, nonwhite labor, in the Exposition marketplace and exotic amusements made white women's consumer practices more

\footnotetext{
${ }^{70}$ Kate Stevens Bingham, "Many Indian Baskets and Curios," Oregonian, July 16, 1905, p. 41; "An Indian Exhibit" and "Japanese Village at Work," in Lewis and Clark Journal 1, no. 4 (April 1903), 14, 24; "Tozier Collection," Mss 1609, box 14, folder 10; Captain R.E. Lawton to Goode, Mss 1609, box 10, no. 15. National Guard Captain Dorr F. Tozier presented the largest exhibit of Native American goods, but the Arizona ethnology exhibit and other individuals like "Captain R.E. Lawton," of Buffalo New York also sought vending space at the exposition to sell NativeAmerican manufactures.
} 
visible. Vendors of baskets and curios targeted female consumers shopping for domestic products, clothing, and exotic travel experiences. "Are you interested in BASKETRY? Is ALASKA Represented in your DEN?" read one promotional pamphlet distributed at the Exposition. The pamphlet encouraged fairgoers to extend their touristic travels to include an Alaskan cruise, but at the Fair itself, affluent fairgoers could purchase expensive furs and Native-American baskets brought in from throughout the Pacific Northwest extending up into Canada and Alaska. ${ }^{71}$ In this geographical spectrum, the Exposition factors as one of numerous scripted and unscripted turn-of-the-century "theaters of contact" where Native women sold baskets of various traditional and non-traditional patterns for prices ranging from $\$ 7$ to $\$ 800$. Oral historian and master weaver Mary Dodds Schlick's examination of Pacific Northwest basketry revealed that many weavers developed new styles to suit white consumer tastes and refused to sell other items due to their Native cultural, aesthetic, or practical value. Weavers selectively decided which products to sell to outsiders, reserving others for personal and communal use. ${ }^{72}$ The publicity regarding baskets and so-called curios at the Portland Exposition obscured Native significances and usages - traditional and modern of material items like

\footnotetext{
${ }^{71}$ Pacific Coast Steamship Co. brochure, 1905, p. 10, Mss 1609, box 12, no. 13; Bingham, "Many Indian Baskets and Curios," Oregonian, July 16, 1905, p. 41; Paige Raibmon, "The Practice of Everyday Colonialism: Indigenous Women at Work in the Hop Fields and Tourist Industry of Puget Sound," in Vicki L. Ruiz and Ellen Carol Dubois, eds. Unequal Sisters: An Inclusive Reader in U.S. Women's History (New York: Routledge, 2008), 194-220. Many Native-American agricultural laborers who traveled from Reservations to farms in the Pacific Northwest to harvest crops commonly brought along baskets they had made in their homes during the winter to sell to tourists and collectors who went to the fields of the Pacific Northwest to photograph the workers. ${ }^{72}$ Raibmon, Authentic Indians, 90 - 97. Raibmon's multiple studies of Aboriginal hop-pickers in the agricultural fields of the Pacific Northwest examine how European Americans regarded encampments of migrant Native laborers - men and women - as ethnographic spectacles. Raibmon also emphasized the laborers' awareness of the touristic gaze and used it as an opportunity to expand their trade in curios and baskets.
} 
watertight, thirty-gallon baskets, twined ceremonial hats, and totem poles, for example. ${ }^{73}$ Writing about the Fair's collection of "baskets and curios," one journalist re-interpreted Native women's reluctance to sell traditional hats as an indication of immoral and barbaric cultural practices, "Only a few of the virgin hats and capes are made, as a female must be absolutely chaste to be entitled to wear one. If a woman who has been married wears a virgin hat, she is killed."74 Schlick's inquiry into the cultural meanings and practical uses of basket hats amongst Columbia River Native societies made no reference to their fatal potential. Instead, women - widowed, married, and single - wore the hats for different practical, social, and ceremonial purposes, and for some of the same purposes appropriated by white women like personal adornment and domestic aesthetics. $^{75}$ As was the case for paid Native-American performers, Native-American producers adapted traditional practices to create new forms of labor and cultural expression, and European Americans consistently re-narrated their labor as dying expressions of an authentic but primitive existence.

Eva Emery Dye was not concerned with recovering an authentic local, indigenous identity through exhibits of Native Americans. Rather, she endeavored to access the city’s “foreign” other, China. By Orientalizing Sacajawea, Dye claimed a pioneer access

\footnotetext{
${ }^{73}$ Mary Dodds Schlick, Columbia River Basketry: Gift of the Ancestors, Gift of the Earth (Seattle: University of Washington Press, 1994), 92-93, 32. Native women on the Warm Springs Indian Reservation, located about one hundred miles southeast of Portland, in made twined hats that were prized by white collectors but rarely sold to them. Historian Mary Dodds Schlick's oral histories taken from Pacific Northwest basket weavers revealed that "Many families put these treasures away, and only a few twined hats made their way into private collections and museums....most hats were passed down in a family, willed to someone in death, or, occasionally, buried with the owner."

74 "Many Indian Baskets and Curios," Oregonian.

${ }^{75}$ Schlick, Columbia River Basketry, 26 - 28. Basket hats made by Pacific Northwest Natives traveled to Europe over a decade before Lewis and Clark set foot in the Pacific Northwest.
} 
beyond the Pacific to identify a local extension of Lewis and Clark's journey, hence she portrayed the Shoshone as "beckoning" towards Asia, where she understood North American Natives to have originated (via the Bering Strait). Abandoning the ancient example, Dye chose, locally, "I wish to bring with me on Sacajawea day, as the guest of myself and the Association, a full blood Shoshone Indian of Sacajawea's tribe," she wrote to President Goode. "I cannot give his Indian name...but his adopted name is David Rinearson. So far as I know, he is the only full blood Shoshone Indian in Oregon. Small, slender, Japanese looking, I wish to present him as a sample of Sacajawea's people." Of Dye's many dislocations of Sacajawea, placing Sacajawea in the Orient as a "heroine of Asiatic ancestry and Caucasian future," emphasized U.S. imperial intentions in the Pacific. ${ }^{76}$ As the next chapter shows, evolutionary theories and Orientalism conveyed through exhibits and performances at the Exposition linked Native Americans with Asians through a shared ancient, feminine racial identity. This elision enabled a grand vision of westward moving empire and hinged on Sacajawea prudently yielding a gateway to wealth and prosperity for European-American men. Dye added EuropeanAmerican women to those who benefitted from Sacajawea's self-sacrificing submission to civilization, which united white women with white men in a superior, masculine racial identity.

Just as Dye struggled to maintain control over the exhibition of Native Americans, exposition organizers grappled with numerous disruptions when they placed the Orient on display at the exposition. Fairgoers and performers of varying Asian

\footnotetext{
${ }^{76}$ Dye to Henry W. Goode, June 30, 1905, Mss 1609, box 9, folder 11; Dye quoted in "Copper Mine Named for Sacajawea," Lewis and Clark Journal 1, no. 2 (February 1904), 26.
} 
backgrounds skewed the fair's dichotomies of an ancient East and modern West with expressions of Asian, Eurasian, and Chinese-American modernity. Some of their performances demonstrated a far more disruptive critique of social inequality than those of the suffragists. 


\section{Chapter Two}

\section{Designs of the 'Fair' Orient, Disruptions from Chinatown}

Sacajawea is keeping watch and ward over the outer gates, pointing to the orient, where countless hordes of women still exist in slavery, who shall ultimately look to our enlightened men and women of this Pacific coast for the full fruition of a freedom that has dawned on us already. -Abigail Scott Duniway ${ }^{77}$

Despite the fact that large numbers of men - and a much smaller number of women - traveled east from China, Japan, India, and the Philippines to work and settle in the nineteenth-century North American West, the Portland Exposition did not feature Asian Americans as a part of Oregon's pioneer past. Indeed, it worked to maintain a distinction between Asian and American identities by ignoring, exoticizing, or dismissing Oregon's long-established Asian-American population. Yet at every turn in the city and at the fair, the dense and multisided movements of people, goods, and ideas between the so-called Far East and the American West blurred the concept of a diametrically opposed ancient Orient and modern Occident commonly used to justify European cultural and racial superiority. Official imperial narratives moved east to west, envisioning the Far East as the next western frontier for American expansionism, ignoring related pressures from the west (i.e. Asia) moving eastward. ${ }^{78}$

Although visions of the Orient had long been a part of U.S. world's fairs, West Coast expositions of the early twentieth century staged the Orient as part of a U.S. imperial geography in the proximal Pacific rather than a far-off foreign place. The Exposition stressed imperial benevolence through gendered images and stories about

\footnotetext{
${ }^{77}$ Duniway, "The Pioneer Mother," reprinted in The Oregon Daily Journal, July 6, 1905, p. 1. ${ }^{78}$ Azuma, Between Two Empires, 3-16, 89-111.
} 
"Oriental" heathen men and oppressed - prostituted or foot-bound - women in need of civilization-work. Despite the insistence of cultural depravity and the very real strictures against people of Asian origins on the U.S. West Coast, the limits, slippages, and disruptions around imperial policies and the re-stagings of history were amply displayed throughout Portland in 1905.

The Chinese Exclusion Act of 1882 entailed what Asian-American historians have identified as one of American history's most striking paradoxes. The highly restrictive but ostensibly "open door" politics of the U.S. government towards Asians and Pacific Islanders represented a "simultaneous blurring and reasserting of the OrientOccident boundary," as Shelley Lee has argued, and required a substantial amount of cultural work to maintain, due to exceptions, exemptions, corruption, and elaborate ruses employed by Chinese people to evade and resist the exclusion laws. ${ }^{79}$ None of this narrative made it into the Fairs, which promoted and justified overseas expansionism. At the Portland exposition, for example, exhibits and performances constructed a united but also racially differentiated and hierarchicized Pacific Rim region in the interest of business and profits. Exhibits of Oriental products, people, and customs sought to provide visible evidence of Asian inferiority and render the East submissive to West Coast business and political interests. Ignoring the local prosperity and achievements of Chinese and Japanese residents of Portland and the West, the Fair's exhibits carried out paternalistic displays of "wonderful little brown people" and the "untutored savage," implying unfitness for citizenship and other democratic freedoms in the United States

\footnotetext{
${ }^{79}$ Lee, Claiming the Oriental Gateway, 8-9.
} 
and, at the same time, promoting a stronger U.S. presence in Asia. ${ }^{80}$ Local Asian and Asian American people in Portland could not be contained by these (un)Fair dramas. Their work in trade, tourism, entertainment, and even in parades and public demonstrations of identity in Portland and on the fairgrounds pushed back against racial theories of civilizational advancement on display at the Exposition. The respective performances of Asian modernity organized by local Chinese-American merchants and Japanese politicians and businessmen destabilized the Exposition's vision of the Pacific as a future "American Lake" and Asians as unenlightened Orientals awaiting the influence of American civilization. ${ }^{81}$ This chapter's exploration of the Lewis and Clark Centennial's “American Pacific Exposition and Oriental Fair” themes reveals conspicuous designs of Oriental inferiority and their less coordinated but equally visible disruptions.

\footnotetext{
80،"What to See when you Hit the Trail," Oregonian, July 1, 1905, p. 11; “Tribesmen For Fair," The Morning Oregonian, December 19, 1904, p. 5; Judy Yung, Unbound Feet: A Social History of Chinese Women in San Francisco (Berkeley: University of California Press, 1995), 2. 80 "Our Empire on the Pacific," New York: Leslie's Weekly: Lewis and Clark Centennial Exposition Issue, June 22, 1905, Mss 1609, box 123, folder 12. The 1882 Chinese Exclusion Act barred working-class Chinese and their wives from entry into the U.S. and set a precedent for the future exclusionary immigration policies against almost all Asian immigrants. Family members of U.S. citizens and Chinese merchants, students, and diplomats were allowed access but experienced heightened scrutiny and prodding in West Coast immigration stations. In 1907, Korean and Japanese people were excluded, and in 1917, the catch-all category of "South Asians" was used. The 1924 Immigration Act prohibited immigrants ineligible for citizenship, which denied entry to nearly all Asians as they were seen as incapable of naturalization, it eliminated legal entry for Asians until 1965, and in 1934, Filipinos experienced the same obstruction. The Chinese Exclusion Act was not repealed until 1943 when the United States and Chinese allied during World War II.

81 “Our Empire on the Pacific," New York: Leslie's Weekly: Lewis and Clark Centennial Exposition Issue, June 22, 1905, Mss 1609, box 123, folder 12.
} 


\section{The Far East as the New West}

Containing and 'taming' the Asian Pacific Rim meant, to some extent, minimizing China and Japan as civilizational and imperial powers at the Fair. This containment occurred through a reorientation of national progress towards the Far East, most notably the Philippines. The organizers of the Portland exposition relied on exhibits of Filipino savagery in order to draw a selective correlation between the nineteenthcentury American West and the contemporary Pacific. They hoped that the performances of Filipinos in the Igorrote Village displayed a necessity for U.S. colonial institutions and tutelage akin to those used to assimilate Native Americans, a case harder to make against China and Japan at this point in time. Interestingly, the focus on the Philippines decentered white women's agency in the imperial drama.

Dr. T. K. Hunt, a former U.S. colonial administrator in the Philippines, organized the Filipino village at the Portland exposition after having done the same for the 1904 Louisiana Purchase Exposition in St. Louis. Hunt and his supporters saw the village as serving multiple pedagogical purposes. They felt the exhibit would justify colonial power relations in the minds of white observers and the Filipinos on display. As one journalist argued in the Oregonian, "those visitors who talked with and studied the tribesmen disabused themselves of any impression that the natives could take care of themselves." The same article reported "Filipinos going home convinced that American government is the best thing for them." Not all the lessons learned by Filipinos in the United States were considered appropriate or civilizing. Indeed, Hunt felt the world's fair experience had tainted the performers' authenticity. After the St. Louis Exposition Hunt traveled to the 
Philippines to recruit a new "colony of tribesmen" for the Portland Fair because, the Oregonian reported "the Filipinos who have been here have learned some of the sharp practices of white men and have spoiled the native exhibitions...by attempting to use their knowledge." The replacement of the St. Louis performers ostensibly ensured that "the visitors to the Lewis and Clark Exposition will see natives that represent the various tribes and not a people slightly spoiled by contact with a foreign people." ${ }^{82}$ Given the long history of contact between Filipinos and "foreign" societies, exhibiting "unspoiled" natives required that Hunt ignore these realities and recruit performers from remote areas on the islands who most outwardly contrasted with Anglo-American cultural norms. ${ }^{83}$ Hunt felt satisfied that a select few Filipinos represented the many. The rituals and material culture presented in the village glorified the mission of the rugged pioneerscientist, who set out to tame and analyze the so-called savage.

Organizers of the Filipino village alleged that the exhibit showed "the Filipinos living as they would live if at home and observing their tribal customs and habits." In actuality, as historian Paige Raibmon has argued, "what they were really attempting to create was not something normal in the sense of the everyday, as much as something they considered authentic. ${ }^{\prime 84}$ Reports on the exhibited Filipinos identified episodes of world travel, cross-cultural negotiation, and employment rather than those of quotidian existence. The Lewis and Clark Journal reported, "Young natives...from the desire for

\footnotetext{
82 “Tribesmen For Fair," Oregonian, December 19, 1904, p. 5. The Exposition's organizers were not eager to host the exhibit due to its controversial "savage" performances.

${ }^{83}$ The Igorrotes lived on steep mountain terraces on the island of Luzon where they cultivated ricefields.

${ }^{84}$ “Five Filipino Villages to be on Grounds," The Lewis and Clark Journal 3, no. 1 (January, 1905), 6; Raibmon, Authentic Indians, 38.
} 
making money...were loath to go home," however, another piece in the journal described them as "pining to return to their retreats in the island province.." ${ }^{.5}$ Despite opposing responses amongst the Filipinos, white observers framed both attitudes as signs that Filipinos should not remain in the United States.

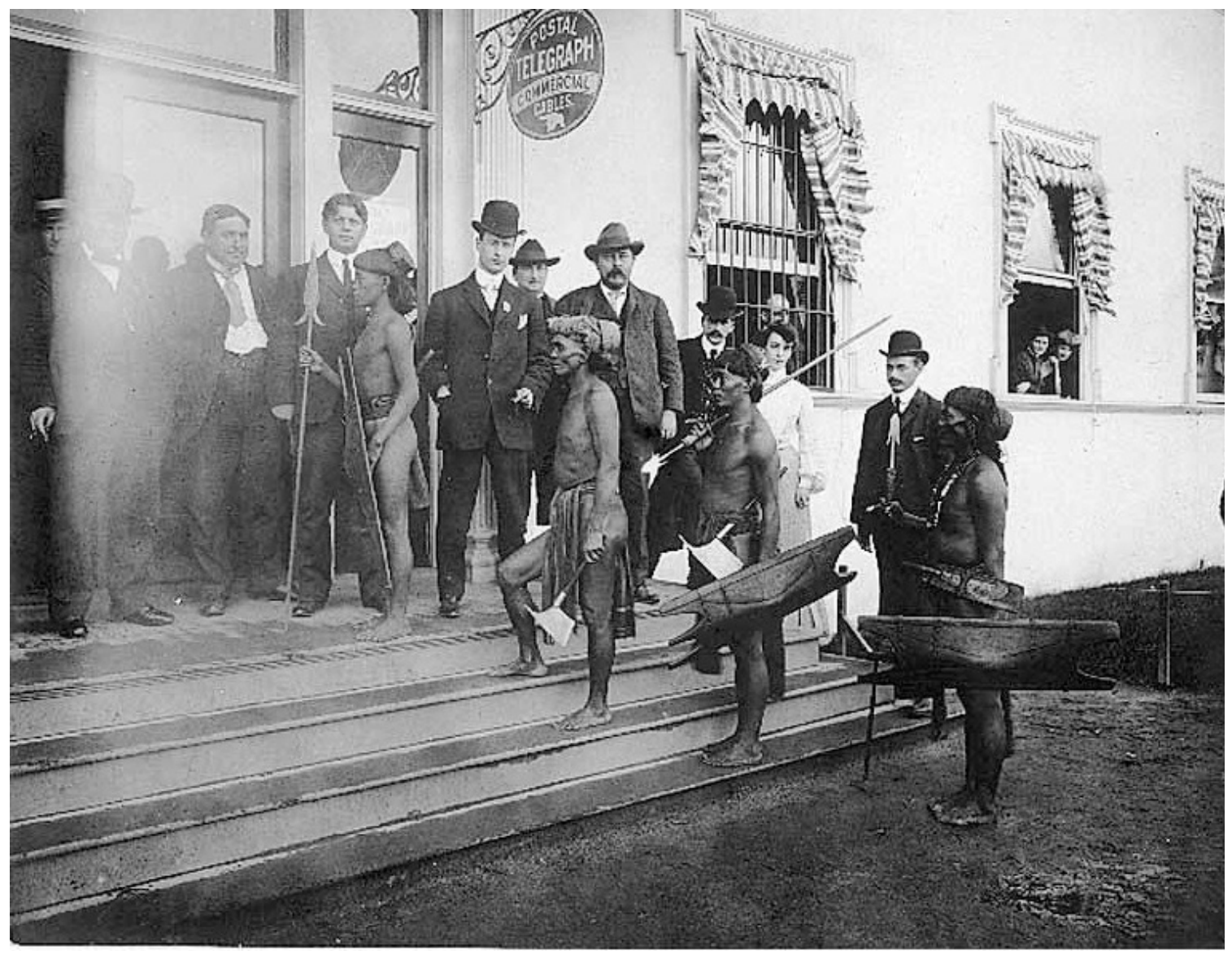

Image 2.1 Igorrote men and their American spectators. Clothing or a lack thereof additionally factored as a measure of civilizational progress. In this scene, the Fair's "Filipino Village" appears as a mobile spectacle. ${ }^{86}$

85 "Five Filipino Villages," Lewis and Clark Journal, 6; "The Filipino Village," Lewis and Clark Journal 2, no. 5 (November, 1904): 3.

86“"Filipino Village," University of Washington Libraries, Special Collections, Lewis and Clark Exposition Repository, PH Coll 391, box 1, folder 15. 
For female social activists, U.S. expansion into the Pacific also broadened the realm of their civilizing mission, which enhanced their moral authority in professional and public roles. Members of the Lewis and Clark woman's club of McMinnville, Oregon, asked President Goode to hire women like Mrs. Capt. H. L. Heath as "a Commissioner to the Phillipines [sic] in behalf of the Board of woman Managers." The clubwomen claimed that after her two-year stint in the Philippines, Heath's "unsurpassed" expertise would provide "material and data concerning the work and social condition of the Phillipine women." ${ }^{87}$ Goode neither created a women's board nor did he employ Heath; however, indigenous Filipinas performed in the Filipino village exhibit. The corporate and federal administrators of the Fair's Government Island marginalized white women in the management of its exhibits, however, gender still worked to distinguish levels of savagery amongst the Filipinos on display. Observers regarded "dog-eating villagers" as the most savage people on display at the Fair. One commentator reassured the public that only men consumed the meal, "no women are to partake of this canine relish." 88 Another article in the Lewis and Clark Journal claimed that Visayan women represented the most civilized of the savages. Appearing in "picturesque homes...composed of bamboo" on the fairgrounds - a domestic scene made public - the women performed domestic labor for a public audience. "The women are expert weavers," the journalist reported, "it is a wonderful sight to behold them combing

\footnotetext{
${ }^{87}$ Miss Grace Newell and Mrs. Laurence L. Niekeim to the Board of Directors of the Lewis and Clark Centennial, January 7, 1903, Mss 1609, box 12, no. 5.The Woman's Club of McMinnville wrote to Goode two years before the Fair. Their letter revealed an assumption that, like previous world's fairs, the Portland Exposition would employ a Board of Woman Managers to incorporate women and women's accomplishments into the exhibits.

${ }^{88}$ “The Filipino Village," Lewis and Clark Journal 2, no. 5 (November 1904): 3 - 4; "Five Filipino Villages," ibid 3, no. 1 (January 1905): 6 - 7.
} 
out long strands of pineapple fiber and making beautiful cloth on hand looms." The article did not credit Visayan culture for the display of civility but rather attributed it to the women's capacity to emulate Europeans, "The Visayan girls are of a pleasing type and all are trained to the effusive Spanish standard of politeness." ${ }^{, 89}$ Displays of dogeating men justified U.S. power in the Philippines, which worked in tandem with portrayals of indigenous women as prepared for Anglo-American assimilation.

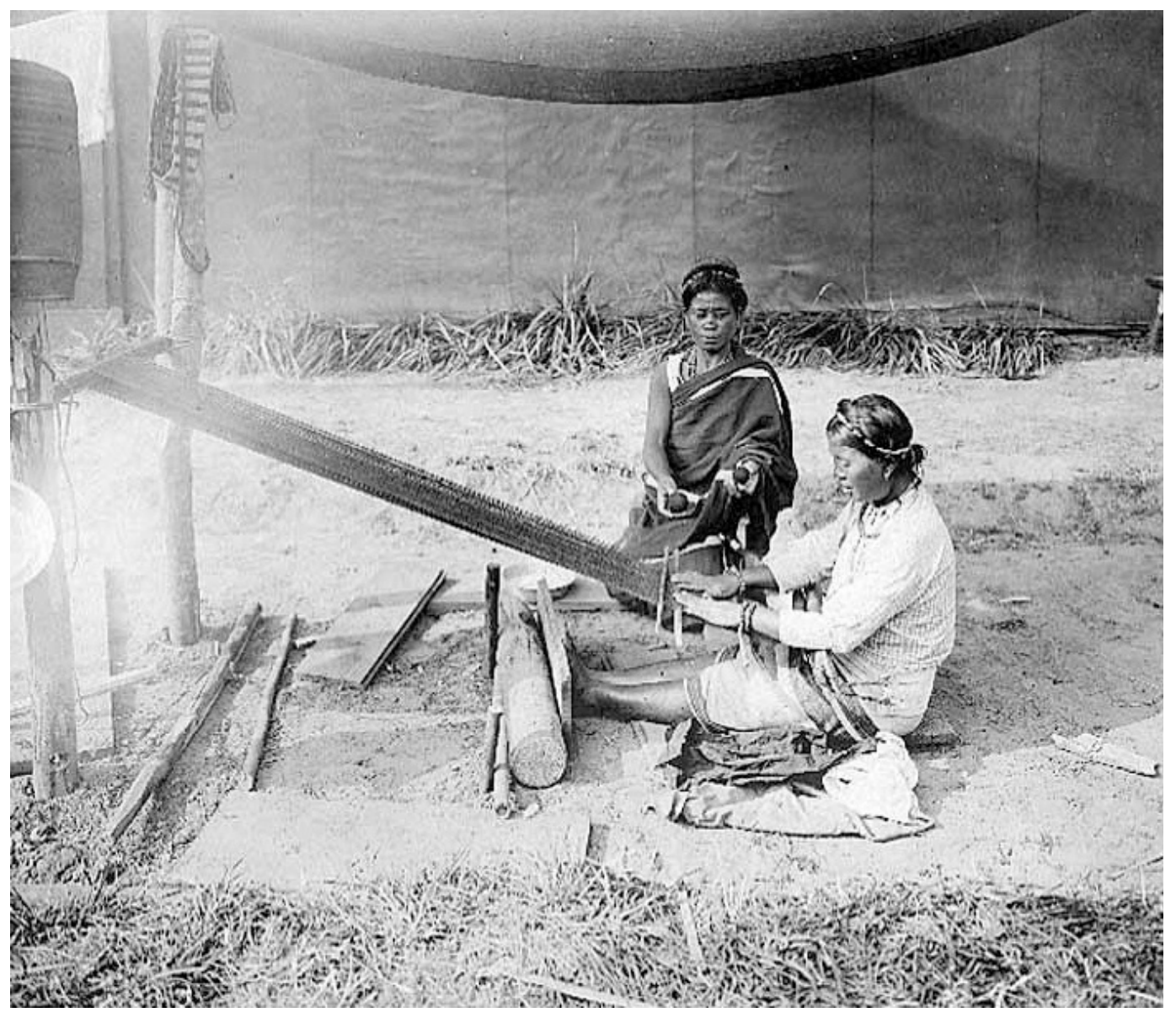

Image 2.2 Visayan Weavers, "Igorrote women weaving fabric at the Igorrote Village, Lewis and Clark Exposition, 1905," University of Washington Libraries, Special Collections, Lewis and Clark Exposition Repository, PH Coll 391, box 1, folder 15. White reporters portrayed native women's work as authentic existence rather than labor.

${ }^{89}$ Ibid. 
The Portland public responded in unintended ways to the Filipino visitors. Often rooted in the same racial ideology used by the U.S. government to legitimize conquest, protests of the Filipino village, like those waged by McBeth and Dye against "wild, long haired" Native Americans, opposed performances that placed "civilized" people in close proximity to "savagery." One protestor, who wrote to President Goode as the collective "Citizens of Nob Hill," threatened to boycott the exposition unless Goode closed the Filipino village. "Hundreds of our people will keep clear of your fair from now on. Unless you close these disgusting vagrants out," warned "Citizens," "You would do a grand thing to get them back to Seattle Tacoma or hell, where they came from." To further the claim of a propertied citizenry unified against savagery, "Citizens" challenged Goode's masculinity and dehumanized the Filipino performers: "Portland people have no use for these; we would suggest that you reinstate your manhood, and close such a disgusting, sore; We expect better things from you." "90 "Citizens" lambasted Goode for allowing the cooking and eating of dogs in public view at the Fair, whereas the exposition's planners envisioned the staging of this seemingly barbaric practice as evidence of the need for U.S. rule in the Philippines. A history not staged at the fair was that of Lewis and Clark also regularly engaging in the so-called savage practice of eating dog during the expedition. One of the army corpsmen wrote, "some of our party killed a fat dog, which they had got from the Indians at the last Village that we passed through. They roasted \& eat it in the Evining [sic]." ${ }^{91}$ Protests of and promises for the Filipino

\footnotetext{
${ }^{90}$ Citizens of Nob Hill to H.W. Good [sic], September 13, 1905, Mss 1609, box 12, folder 5.

${ }^{91}$ The European-American corpsmen preferred dog meat to salmon during their time on the Pacific coast. Hoxie and Nelson, eds., Lewis and Clark and the Indian Country, 154 - 155; Sergeant John Ordway and Private Joseph Whitehouse, journal entries, October 4, 1805 and
} 
Village constructed the regulation of public space and insurance of public safety and morals as properly masculine work.

Portrayals of nomadic and impoverished Natives simultaneously excused and justified the United States for causing their dislocation and hardship. The white residents of Nob Hill, for example, argued that "vagrants" threatened their rights - as propertied citizens - to determine the boundaries of social life in Portland. Asserting rootedness and rights in their nativity as "Portland people" and diminishing Filipino claims to land and dignity as a dislocated and conquered people, "Citizens" evoked the imperial mythology of Native lands as unoccupied territories. Envisioning the West as the birthright of white settlers and Filipinos as lacking ties to anywhere both reflected the notion that land not used or owned in the style of Europeans were unoccupied, uncultivated, and free for the taking. As one reporter put it, the Government Exhibit set out to "illustrate the resources and products of our Oriental possessions." Denying the capacity of a people to selfgovern simultaneously entitled the United States to their land and resources. ${ }^{92}$

Scenes of so-called vagrancy disrupted the Exposition from within its human exhibits as well as its crowds. The Fair's organizers allowed the Filipino actors to remain on the fairgrounds and continue their performances. African-American fairgoers accused of vagrancy, however, lacked a scripted belonging in a Pacific Rim hierarchy. Indeed,

William Clark, journal entry, April 27, 1806, both reprinted in The Journals of the Lewis and Clark Expedition (Lincoln: University of Nebraska Press, 2005), http://lewisandclarkjournals.unl.edu/read/? xmlsrc=1805-07-28.xml\& xslsrc=LCstyles.xsl (accessed July 20, 2012). In Portland today dogs carry substantial commercial and cultural weight, to the extent that the consumption of their meat in public would probably provoke more outrage than it did at the 1905 Exposition.

92 "United States Government Board for Lewis and Clark Exposition," Oregonian, January 2, 1905, p. 4. 
given that the Oregon Constitution officially denied African Americans residency in the state of Oregon, and while the law was not fully enforced, black Portlanders and visitors put themselves at risk when appearing in the public spaces of the Fair. Pointing out a "large and noticeable aggregation of colored men and women," the Oregonian drew attention to African-American fairgoers as part of the spectacle. Describing the scene as "visitors and residents" going to the Fair, the journalist hinted at the accepted disruption of constitutional law, but the arrest and expulsion of one fairgoer on the Fair's amusement strip, the Trail, established a municipal authority over the city's AfricanAmerican residents and visitors that underscored their alien nature. ${ }^{93}$ The court case of a "colored man" named Washington, arraigned on a charge of vagrancy, highlights the danger, for some, in being seen at the Exposition:

"Hit the Trail, eh?" said Judge Hogue. "Yes, sir, I done hit it hard, sah," replied Washington. "Well, sah, I'se ready, sah, to hit de rail, now, sah," replied Washington, twinkling his eyes, and glancing furtively at the Judge. "I guess he wants to hit the grit for some place away from Portland," suggested Deputy City Attorney Fitzgerald. "I'se willin' to hike back to Seattle, if you are willin' to let me," volunteered Washington. "Very well - hike right quick, and don't turn to look back," said Judge Hogue. ${ }^{94}$

\footnotetext{
${ }^{93}$ Oregon State Constitution, Article I, Section 35, 1859; "By the Thousands, Visitors and Residents Go to Fair Grounds," Oregonian, February 27, 1905, p. 8; David Peterson del Mar, Beaten Down: A History of Interpersonal Violence in the West (Seattle: University of Washington Press, 2002), 94, 105 - 109. For more on Portland's African-American history, see Elizabeth McLagan, A Peculiar Paradise: A History of Blacks in Oregon, 1788 - 1940 (Portland, Ore.: Georgian Press, 1980). The 1849 Territorial legislature outlawed slavery but made it illegal for African Americans to live in Oregon. It became a part of the 1859 state constitution in the form of an exclusion clause enacted by a popular vote and was not repealed until 1926. Historians of the West, like Peterson del Mar and McLagan, and have studied African-American communities that developed in the West despite Jim Crow-like regulations or "sundown" laws that barred their presence in the city after dark. An estimated one thousand black Americans lived in Portland by 1910. In many municipal cases, African-American men were issued fines rather than expelled from the city, but their fines averaged about $\$ 60$, which was two-to- five times the fine demanded of other male defendants, including men of Asian descent.

94 "Offenders Before Judge Hogue," The Morning Oregonian, June 11, 1905.
} 
The journalist portrayed Washington's colloquial speech as so foreign as to require translation for the judge. Other offenders in the article received fines for their misdemeanors; they are neither instructed to leave town nor are they quoted with attention to race or vernacular. As historian David Peterson del Mar has shown, African Americans made up less than one percent of Portland's population but constituted 3.9 percent of those arrested in the city. His analysis of court documents and the city's newspapers revealed, "the highest arrest rates and average fines by far were inflicted on Portland's tiny complement of African Americans, a group that its newspapers commonly associated with violent criminality." "95 The description of Washington's twinkling eyes and furtive glances supported a dandified image used to criminalize African- American participation in political and public contexts.

The federal government controlled the exhibition of the Philippines, which made it possible to display the islands as an "oriental possession" of the United States. Exhibiting Japan and China, non-colonized Asian countries with less "primitive" material cultures, on the other hand, required different framings and cooperation with Japanese and Chinese envoys sent to develop their national exhibits, and not surprisingly, allowed more room for Asian womanhood and white women's interventions into their portrayals.

Some white Portland commentators regarded the capacity to stage a sophisticated exhibit of the nation-state as an indicator of modernity. When China failed to install a national exhibit at the Portland Exposition, the government's inability to provide a model of the country's accomplishments seemingly affirmed China's low civilizational status.

\footnotetext{
${ }^{95}$ Peterson del Mar, Beaten Down, 109.
} 
"Finding the Chinese government a trifle lacking in enterprise," the Oregonian reported, the Chinese province of Shantung "sent a full exhibit...on its own behalf." Taking the initiative where the national government had failed, the reporter argued that the province "wishes to become known as the most progressive province of the Empire and to make its products known to the world. ${ }^{96}$ Americans regarded reluctance to trade and engage in international expositions as a sign anti-modern passivity. Journalist Jane A. Stewart described the Portland exposition itself as an opportunity to reawaken ancient Asian civilizations. Describing the "Re-awakening of Asia" as one of the exposition's central themes, Stewart argued that the U.S. exposition of Asia will "awaken the East to the reawakening of Asia," investing in the United States the power to civilize even noncolonized Asian countries. ${ }^{97}$ The Exposition's organizers used the notion of a reawakened Asia to account for displays of Asian modernity.

Japan, by the 1900s, had become a disruptive case among Westerners as a nonEuropean industrial and military power. In May of 1905, the imperial Japanese navy defeated Russia in the battle of Tshushima, which resulted in the transfer of Russian colonial territories to Japanese control. Japan's empire-building and military prowess, like that of the United States, destabilized older European powers - namely Russia and Spain - to enter into an international race to claim overseas territories. Japan's Europeanstyle progress additionally challenged the perception of the Orient as fixed in antiquity and open to conquest by the West. Attempting to alleviate the tension of a confused EastWest divide, the fair's organizers rearticulated the United States as the catalyst of

\footnotetext{
96 "Shantung Makes Its Own Exhibit," Oregonian, August 8, 1905, p. 8.

${ }^{97}$ Jane A. Stewart, "The Latest Great Exposition - Portland's Pride," Leslie's Weekly: Lewis and Clark Centennial Exposition Issue, June 22, 1905, p. 586.
} 
Japanese progress with the help of an enormous financial contribution from Japan. A "water carnival" held on Japan Day at the fair displayed floating replicas of modern warships. A golden throne featuring Japanese naval officers clad in $\$ 1,500$ uniforms floated carried actors portraying the Japanese emperor and U.S. Commodore Matthew Perry. A contrasting "glare of red fire" emanated from other floats surrounding the Navy whites and battleship grays. Japanese lanterns, dragons, a houseboat, and a "floating tea garden, with Geisha girls" brought the display of Japanese martial manhood - mitigated by U.S. imperial manhood - into gendered relief. Rowboats filled with white women, dressed in white - the wives of the exposition's organizing elites - further inscribed the scene with gendered racial difference. ${ }^{98}$

Female Japanese performers, dressed in kimonos, appeared throughout the Exposition as representatives of a feminine, traditional Japan. "The Japanese girls flutter about like creatures from out a fairy book," read one photographic souvenir book describing the "Fair Japan" exhibit. Using the label "fair" seemed to indicate a whitening of Japan, largely through the metaphor of female beauty and desireability in the gazes of white men. Meanwhile, a magazine article covering the Exposition celebrated the Japanese woman Marchioness Oyama as “a pioneer of progress for her kind.” Imagery and rhetoric regarding Japanese women ebbed and flowed between modernity and antiquity to evoke Japan's unsettled and unsettling liminal status. Sometimes contemporary and sometimes traditional, Japanese women appeared in some places as

\footnotetext{
98 "Feast of Lanterns: Japan's Great Day at the Centennial Exposition," Oregonian, August 27, 1905. Often framed in the language of imperial benevolence, in 1854, Commodore Perry, accompanied by a fleet of U.S. warships, forcibly "opened" Japan to U.S. trade with the Treaty of Kanagawa.
} 
liberated moderns and elsewhere as enslaved antiquities. Japanese men also demonstrated liminality. The Trail's Japanese Village included male performers in domestic settings that contrasted with the water carnival's display of modern, masculine military strength. "Here the tradesman of the middle ages may be studied, and naïve street scenes of the long ago will be reproduced with many bizarre and grotesque effects," one commentator observed of the Trail's Asian amusements. "Thatched roofs will be seen hobnobbing with roofs of Spanish tiles, steep Dutch gables, the quaint massive half timbered houses of Old England and the out-reaching Oriental roofs of lattice-work houses of Japan, gay with lanterns," the Fair made the antiquity and difference of Japan palpable, casting it as a place akin to Medieval Europe and framing its exhibition as part of an anthropological study of the "bizarre and grotesque." $" 99$

The use of exhibition, clothing, and architecture to differentiate an exotic - if not erotic - Oriental identity occurred throughout the turn-of-the-century West and was often tied to gender. Despite visions of Japanese modernity, as historian Shelley Sang-Hee Lee has argued of the gendered staging of Japanese women at the 1909 Seattle World's Fair, exhibits of Japan in the American West ultimately reinforced a "conceptualization of the Pacific world in which East and West were brought together yet still differentiated by clear racial markers." ${ }^{, 100}$ Japanese women and men, through their traditional dress, evoked a feminine antiquity and unchanging otherness. In contrast, other Japanese men clad in U.S. navy-style uniforms evoked Japan's coming-of-age and its modern identity under U.S. imperial tutelage.

\footnotetext{
99 "Bridge of Pleasure," Lewis and Clark Journal 1, no. 4 (April 1904), p. 8.

${ }^{100}$ Lee, Claiming the Oriental Gateway, 54.
} 


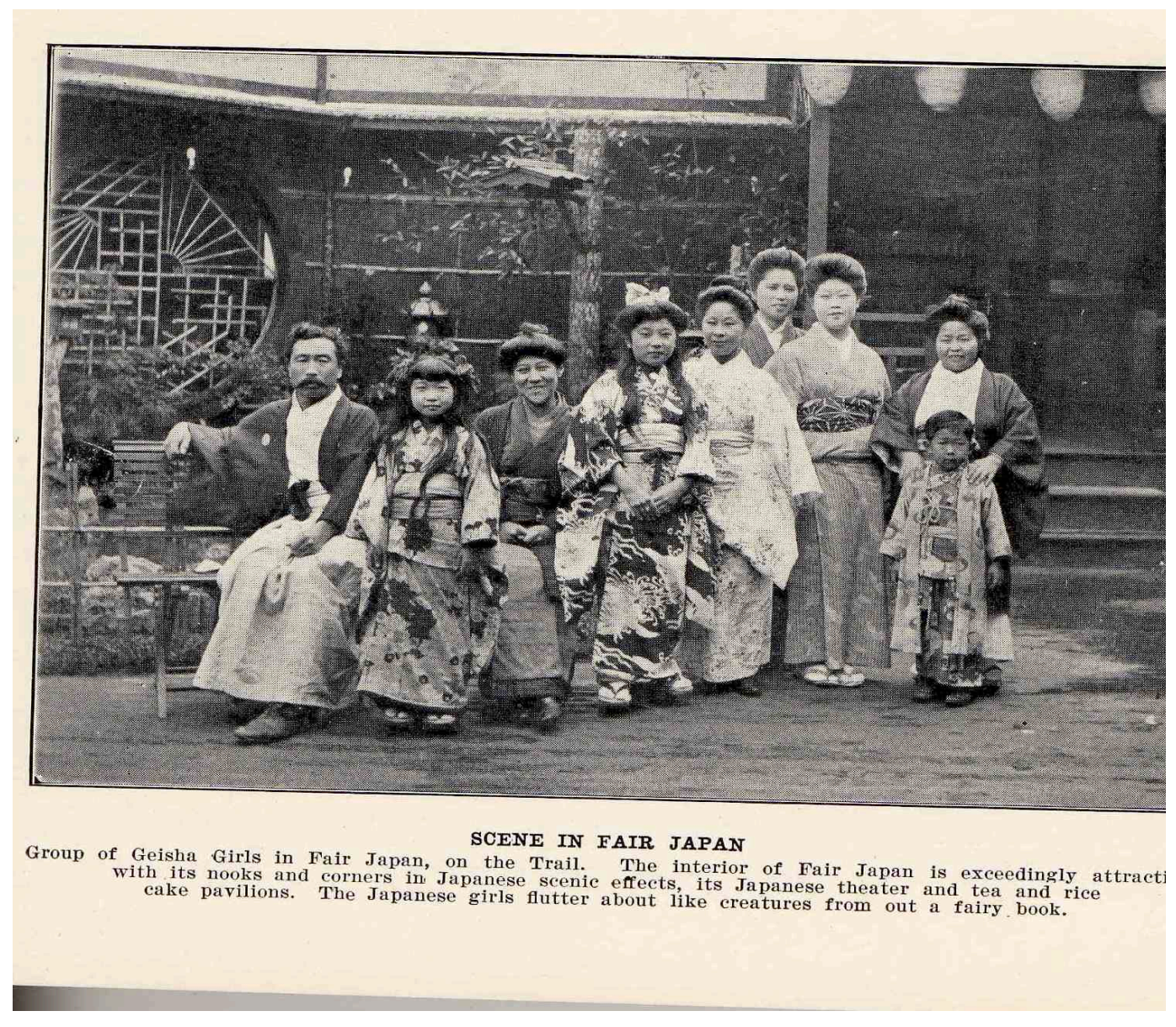

Image 2.3. "Scene in Fair Japan," in Sights and Scenes at the Lewis and Clark Centennial Exposition in Portland, Oregon: Very Completely Illustrating the Fair (Portland, Ore.: R. A. Reid, 1905), in Kiser Photo Company photographs, Org. Lot 140, box 11, folder 22.

For Japanese women especially, turn-of-the-century Anglo-American frameworks rendered them objects of U.S. liberation. Marchioness Oyama, the wife of an eminent Japanese marshal, appeared in an article featured in the special Lewis and Clark edition of Leslie's Weekly that was written by its war correspondent Eleanor Franklin. For Franklin, Oyama's ability to communicate in a "low, musical voice in perfectly chosen English speech" minimized "the gulf which is supposed to exist between us of the Occident and her kind of the mystic old East." A former Vassar student and Red Cross nurse, Oyama was considered an Americanization success story. "Bridged by a sense of 
undeniable sisterhood," Franklin framed Oyama as equal yet temporally strange due to her childhood. "The marchioness is a modern in the extremest sense of the word, yet she was born and spent all her childhood and early girlhood in such social conditions for women as belonged to the Middle Ages," Franklin argued. The class-based criteria for Franklin's modern "sisterhood" included a U.S. college education, Red Cross service work, fluency in English, and a large European-style home. Franklin's temporal displacement of Oyama's youth into a nineteenth-century Medieval Japan also conveyed Japan as a reluctant apprentice under U.S. instruction, "[Oyama] was born in the early part of that awful first twenty years which followed the advent of Commodore Perry with his gift of new life and enlightenment to this people." ${ }^{\prime 101}$ By depicting modernization as a process occurring because of United States military and political power over Japan, and women's advancement as a recent event in the life of Oyama, Franklin maintained a Eurocentric boundary between East and West. "Uplift" recuperated the modernized Oriental for a self-serving, racialist narrative of progress.

The Japanese-American writer Yone Noguchi presented a similar view of Oyama's Westernization in the New York-based National Magazine. ${ }^{102}$ However, Noguchi accounted for Oyama's intellectual and economic successes as derivative of both Japanese and American influences. Oyama's "model Japanese mother...disciplined

\footnotetext{
${ }^{101}$ Eleanor Franklin, "Strange Story of Marchioness Oyama, wife of Japan's Great FieldMarshal," Leslie's Weekly: Lewis and Clark Centennial Exposition Issue, 590.

${ }^{102}$ Yone Noguchi, "Marquis Oyama and His Wife," National Magazine (New York: New York, 1907), 438.
} 
all of her children well and instructed them nobly." ${ }^{, 103}$ Noguchi also quoted Oyama extensively whereas Franklin relied chiefly on her own interpretation of Oyama. Noguchi asked, "Do you think that the Japanese women will be speedily Americanized?" and quoted Oyama as responding affirmatively, but Oyama's description of Americanization challenged many visual symbols of progress in the Anglo American imaginary. "Many women actually thought that American dress and...food were all that was necessary to be Americanized!" remarked Oyama. "They did not understand that they could be Americanized under the Japanese kimono and wearing the wooden clogs." To Oyama, Americanization meant Japanese adaptations of U.S. nationalism and imperial culture, not total assimilation. Her reference to the kimono could indicate her class bias or recognition of U.S. perceptions of Japanese women as geishas. ${ }^{104}$

During the Exposition's Run, the Oregonian listed Marchioness Oyama along with Susan B. Anthony, Marie Curie, Sarah Bernhardt, the Queen of England, and the Empresses of Russia and China as the world's most famous women. The journalist applauded the European women and Oyama for their contributions to "art, philanthropy, literature, science and reform," but the Chinese Empress Tzu-hsi derived her fame from her reputation as a "grim, cruel, bloody and really terrible woman... a veritable female incarnation of the old Chinese." Using Chinese gender roles to conceptualize her infamy and power, the journalist wrote, "In benighted China, where the woman of ordinary character, no matter what her rank, is only the depraved toy of man's passion, she so

${ }^{103} \mathrm{Ibid}, 442$. Oyama praised the nationalism of Japanese mothers whose volunteer work supported their country in wartime. She also saw the Russo-Japanese war as watershed for women's social advancement.

${ }^{104}$ Ibid. 
managed affairs as to rise to the head of the state." ${ }^{, 105}$ In Portland, _ Chinese women of "ordinary character" registered as launderers, students, laborers, and one as a photographer. They did not receive journalists in their parlors like Oyama nor were the more socially active among them asked to join the local suffrage movement, but local Chinese American women did appear frequently in the pages of the Oregonian. ${ }^{106}$ During the Chinese New Year celebrations in Portland's Chinatown, one journalist observed, "Chinese children ran about the streets in gaudy costumes, and not a few women were seen, though they took care to remain in the background. Every Chinaman, from the poverty-striken to the most wealthy, had on the best and most expensive clothes in his possession and was parading about the streets." ${ }^{\prime 107}$ At the time of the Exposition about seven thousand Chinese Americans and about one thousand Japanese Americans lived in downtown Portland. Their local populations continuously increased between 1900 and 1910, and represented the majority of Portland's foreign-born population. ${ }^{108}$ Indeed, local Asian Americans made frequent appearances at the Fair as tourists and performed, less frequently, demonstrations as activists at the Exposition; local Chinese

\footnotetext{
${ }^{105}$ Dexter Marshall, "Who are the Six Most Famous Women?” Oregonian, May 25, 1905, p. 40. As a recent historian of Chinese art in the United States has pointed out, the turn-of-the-century Japan "mania" depended upon Chinese precursors, even as these precursors - and people - were erased, displaced, excluded and ignored

${ }^{106}$ Jensen, "Revolutions in the Machinery," 343. In 1911, Chinese-American women in Portland established the Chinese American Equal Suffrage Society. Members challenged Oregon's delay in passing suffrage by comparing the state to the newly established Chinese Republic whose government allegedly planned to include women's suffrage in its new Constitution, which, in the end, did not occur until much later.

107 "New Year's Din in Chinatown," Oregonian, February 9, 1905, p. 8.

${ }^{108}$ Paul G. Merriam, "The 'Other Portland': A Statistical Note on Foreign-Born, 1860 - 1910," Oregon Historical Quarterly 80 (Fall 1979): 266-268.
} 
merchants also profited economically from the influx of tourists that the Fair drew to the city. Their experiences been understated or overlooked by previous historians of the Fair.

\section{The Far West as the New East}

Chinatown...is in the very heart of the city.

-Seid Back, Jr., A Trip Through Chinatown

While little attention was paid to China proper at the Exposition, Portland's

Chinese American community organized expressions of Chinese American patriotism at

the Fair. ${ }^{109}$ Like the suffragists, they used popular forms of performance and publication such as parades and tourist pamphlets to publically display and voice their allegiance to a nation-state that restricted or rejected their participation, which challenged the narratives presented at the Exposition and in national media to justify race-based citizenship and immigration policies. Just as "Citizens" failed to prohibit the Filipino village, the exposition organizers failed to suppress visiting and local Asians from disrupting the racial criteria for civility, modernity, and land ownership through various demonstrations of modern Asian identities on and around the fairgrounds.

Local Chinese Americans contradicted the presentation of the Orient as a foreign land distinct from or submissive to the United States, though, unlike the Fair's re-stagings

109 "Shantung Makes Its Own Exhibit: Delay of Central Government Leads Chinese Province to Take Action," Oregonian, August 8, 1905. At the time of the Exposition, the Chinese government was on the verge of boycotting trade with the United States in opposition to increasingly restrictive U.S. immigration exclusion laws against Chinese migrants. While exclusion laws had been in place since the $1880 \mathrm{~s}$, in practice, local enforcement of exclusion laws increasingly denied entry to many non-excluded Chinese merchants and students, as well as U.S.-born Chinese and long-term U.S. residents traveling home from visits to China. China's refusal to participate in the Exposition derived from these tensions and their continued resistance at the 1909 Seattle Exposition indicated China's continued protest of U.S. immigration policy. 
of Japan and Japanese-ness, Chinese women hardly appeared in the Fair's visual landscape. Chinese Americans whose appearances and actions neither fit the mode of heathenism nor of European-American mimicry offered countervailing visions, albeit fewer, of identity and belonging in the Pacific Rim. Using the print media, a crucial forum and instrument for disrupting and re-narrating the exposition's story of the West, Seid Gain Back, Jr. published a souvenir book entitled A Trip Through Chinatown for distribution at the exposition. The book, written in English, offered an examination of Portland's Chinese-American community that provided a counter narrative to those of Oriental fixity and yellow-peril immorality - the cultural rationales that substantiated systemic and popular racism. Back, a merchant, interpreter, community leader, and attorney, offered a perspective resonant with that of the suffragists in its use of nationalism and Eurocentric progress to protest contemporary limitations on U.S. citizenship and individual rights. ${ }^{110}$ A Trip to Chinatown described Chinese Americans in Portland as diverse and path-breaking: "In no other place outside the Celestial Empire do we find the Chinese so varied in condition, so truly heathen and so thoroughly Americanized, as in the Rose City of the West." Applying mainstream American criteria

\footnotetext{
${ }^{110}$ Back worked as a contract interpreter for the U.S. district court and official translator for the Chinese in Portland and often interceded on the behalf of West Coast Chinese Americans. As an intelligent and socially well-connected interpreter, Back quickly rose through the local ranks of the Bureau of Immigration. His widespread acceptance amongst Portland's political and social elites eventually led him obtain a supervisory position over other Chinese interpreters whom he inspected for his superiors; often using his own conservative values to denigrate their moral, intellectual, and social character, which often put him at odds with members of the local Chinese community. See Wong, Sweet Cakes, Long Journey, 191 -193.
} 
and terminology to measure fitness for equal rights, including women's liberation, Back, Jr. differentiated between Chinese Americans and Chinese in China. ${ }^{11}$

Deploying the analogy between geographic mobility and social progress, Back contended that the eastward movement of Chinese migrants and their experience in the West had a civilizing effect on the Chinese American. His characterization of Chinese Americans as occupying a "position of influence and learning," and of Chinatown as located in "the heart of the city," suggested that in addition to their reception of European-American values - learning - Chinese Americans also had a self-determined impact on American society -influence. Back's textual portrayal of Chinatown disrupted the exclusion of Chinese Americans from the Exposition's racially exclusive representations of American identity. Using modes of communication and forms of unofficial social connectivity similar to those employed by white suffragists to argue their primacy in historic and contemporary pioneer roles, Back and his American-Born Chinese organization more radically disrupted the Exposition by confusing the East-West binary used to exclude people of Chinese origin from rights in the United States.

Pointing out the fitness of a people to modernize and self-govern along the criteria for modernity and civility used by European and European-American imperialists to justify conquest highlighted the contradictions of liberalism and democracy perpetrated by imperial nation-states. Many anti-colonial nationalist movements organized by colonized elites and used against European colonizers employed this form of protest. In the case of Portland's Chinese-American elites, however, the term anti-imperialism does

\footnotetext{
${ }^{111}$ Seid Gain Back Jr., A Trip through Chinatown. Chinese Souvenir of the Lewis and Clark Centennial Exposition at Portland, Oregon (Portland: R. W. Steel, 1905).
} 
not capture their social activism. Instead, Back better represented a transnational identity similar to that applied by historian Eiichiro Azuma to Japanese Americans in the West. Azuma explained that transnational identities often do not fully transcend the nation-state but rather take interstitial positions between multiple, sometimes clashing, nation-states. The transnational, what Azuma also referred to as "inter-National," identity of Chinese Americans in Portland challenged the existence of a monolithic national and cultural identity through experiences of mobility and labor within a global economic system, and by constructing new social relationships and making cultural heterogeneity visible. ${ }^{112}$ Although Back's conservative and Eurocentric portrayal of Chinese-American progress resembled tactics of assimilation and accommodation, these terms also fail to capture his resistance to the racial hierarchy imposed by the U.S. nation-state. Rather, Back's displayed an "oppositional conformity" that redirected the touristic gaze of the Exposition towards a de-racialized view of the national community and remapped the movement of pioneers to depict a distinctly American Chinese community equal to - but which had arrived from the opposite direction of - white American pioneers. ${ }^{113}$

Recognizing the power of gendered performances as an important contestation of racial exclusion, Back also organized parades that staged American-born Chinese masculinity and patriotism in the streets of downtown Portland during the Exposition. The American-Born Chinese Brigade, a paramilitary organization made up of young Chinese-American men, was organized by Back in 1898 with the help of his friend,

\footnotetext{
${ }^{112}$ Azuma, Between Two Empires, 3 - 5.

${ }^{113}$ Special thanks to Patricia A. Schechter for pointing out the term "oppositional conformity," which also appeared in Jennifer Bailey, "Voicing Oppositional Conformity: Sarah Winnemucca and the Politics of Rape, Colonialism, and 'Citizenship'" (master's thesis, Portland State University, 2012).
} 
another Chinese-American social activist, Moy Bow Wing and Capt. B. F. Jones of the Oregon National Guard. The Brigade was the only organization of its kind in the United States, and performed for predominantly white audiences in Portland on a regular basis. ${ }^{114}$ Like the spectacle of martial manhood at the Japan Day "water carnival," Back's brigade set out to display "the physical and mental development" of ChineseAmerican men through public, military performances. During the Exposition, the brigade paraded through downtown Portland wielding guns and dressed in U.S. military uniforms. Their performance redirected fairgoers to Portland's substantial, multigenerational American-born Chinese men (especially). ${ }^{115}$ Back expressed organizational agency, and the brigade - unlike the Chemawa school boys who also paraded in U.S. military uniform - operated independently of federal military authority; however, the brigade's obsolete, second-hand military uniforms and their denied entry into the Oregon National Guard signaled a persistence of racialized tension and discrimination. Clearly more was needed than what Back described as "the influence of civilization" for the pioneering Chinese immigrants to obtain socio-political equality. Neither officially colonized nor included in the nation-state, the Chinese-American Brigade presented a transnational and decolonial display of martial manhood overlooked by historians of gender at the Lewis and Clark Centennial Exposition.

\footnotetext{
${ }^{114}$ Wong, Sweet Cakes, Long Journey, 185 - 187. Back tried to enlist as a telegraph operator for the U.S. Army Corps of Engineers during the Spanish-American War but was denied eligibility, apparently due to poor eyesight. His rejection motivated him to form the American-born Chinese Brigade. Chinese Americans in New York attempted to establish a paramilitary organization as well, but lacked the financial and community support needed to sustain the organization. 115 “American/Born Chinese Entertain," Oregonian, May 14, 1905, pg. 27. Back, Jr., A Trip Through Chinatown.
} 


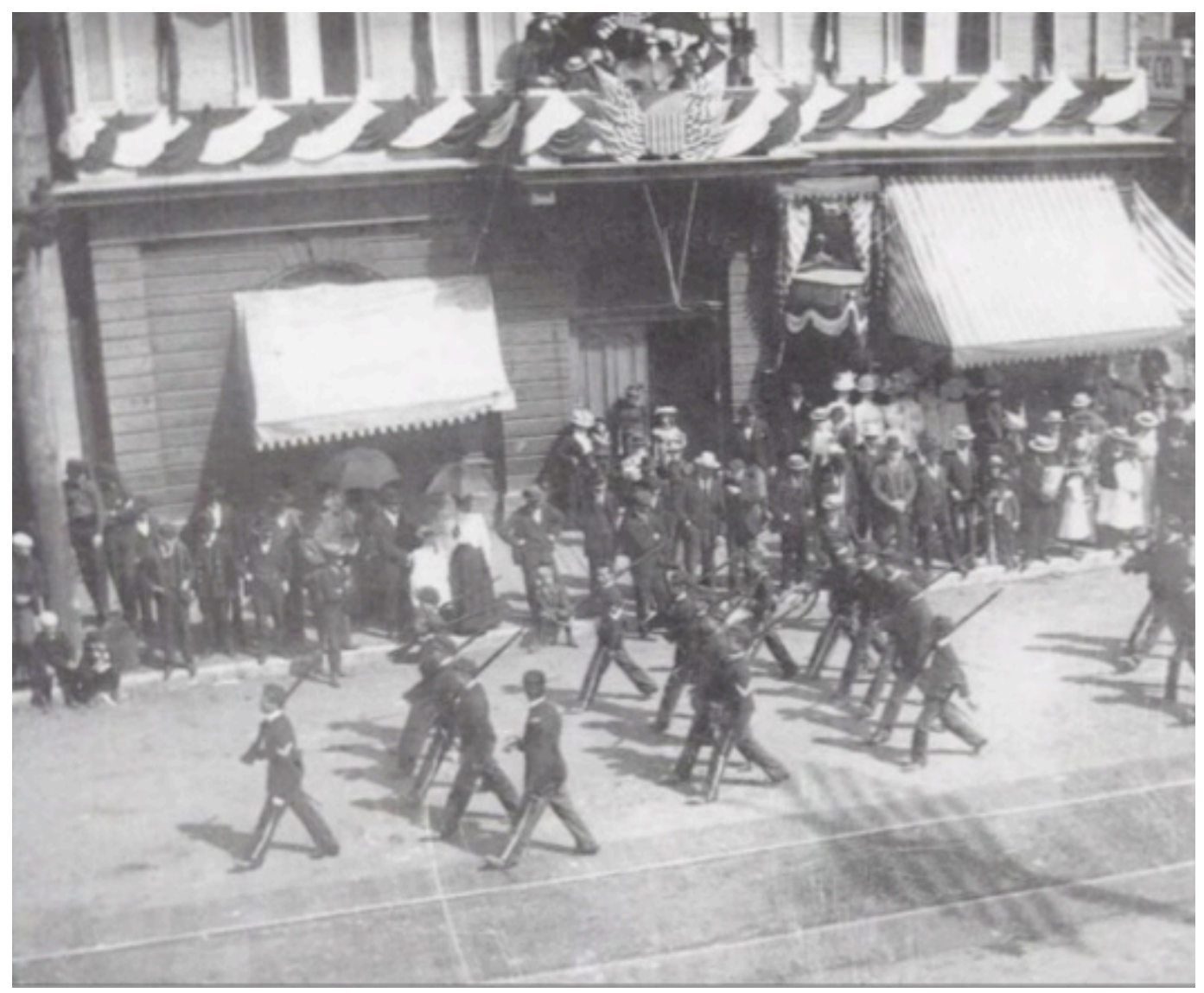

Image 2.4 "The American-Born Chinese Brigade on Parade," circa 1900, OrHi 27104, no. 1918, OHS. The soldiers ranged in age from eight to twenty-six. They wore used uniforms dating back to the Civil War. Local Chinese Americans raised funds for their equipment, uniforms, and office space.

Back's self-representation and the highly masculine portrayal of his community largely erased and displaced Chinese women from the public sphere. Referring to the accepted presence of women in the public sphere as a marker of American - including Chinese-American - progress, Back argued that "only through the garb of the American and the influence of civilization does the respectable Chinese woman ever appear in public.” Back employed a flexible definition of culture to counter stereotypes of Chinese women as either prostitutes or foot-bound and cloistered wives, but in his deployment of certain Victorian gender ideals - like privacy and decorum - he also applied conservative 
restrictions on women's engagement in the public sphere. "The respectable women never appear in a public eating place," Back argued, countering Orientalist stereotypes to redeem Chinese women from their maligned images and develop a gendered ChineseAmerican civility. Formulating a definition and representation of Chinese women that countered white hegemonic images but nonetheless restricted and silenced Chinese women, Back performed what scholar of African-American history Psyche A. WilliamsForson has termed "gender malpractice." Williams-Forson applied this concept to describe "the ways in which those other than black women purport to 'know' and 'think' for them." Unlike the more straightforward hegemonic racist portrayals made by whites of black women, gender malpractice includes the misrepresentations of black women launched from within black communities themselves.$^{116}$ Williams-Forson's concept opens the possibility of a more complex construction of identity, with layers of interethnic and intra-ethnic gender-based erasures, misrepresentations, and "malpractices," and provides a useful tool for analyzing the social activism and self-representations of Chinese Americans at the Exposition. ${ }^{117}$

\footnotetext{
${ }^{116}$ Seid Gain Back Jr., A Trip through Chinatown. Chinese Souvenir of the Lewis and Clark Centennial Exposition at Portland, Oregon (Portland: R. W. Steel, 1905); Psyche A. WilliamsForson, Building Houses out of Chicken Legs: Black Women, Food, \& Power (Chapel Hill: University of North Carolina Press, 2006), 8.

${ }^{117}$ Historians of Asian America have brought to life a much more complicated history of race in the United States through studies of gender and class tensions within and between AsianAmerican communities. These tensions often derived from members of the community crossing lines of ethnicity and class for marriage, dating, and leisure, and often included working-class white communities. See, for example, Eiichiro Azuma, "Racial Struggle, Immigrant Nationalism, and Ethnic Identity: Japanese and Filipinos in the California Delta, 1930 - 1941," Pacific Historical Review 67, no. 2 (May 1998): 163 - 199; Rhacel Salazar Parrenas, "'White Trash' Meets the 'Little Brown Monkeys': The Taxi Dance Hall as a Site of Interracial and Gender Alliances between White Working Class Women and Filipino Immigrant Men in the 1920s and 1930s," Amerasia Journal 24, no. 2 (1998): 115 - 134.
} 
Re-centering the "heart of the city" in Chinatown, Seid Back, Jr. and his American-Born community organizations adapted forms of public participation that they employed on a regular basis in downtown Portland to make visible their allegiance to the United States. Back used the same forms of public participation and performance, as well as the same language and publicity employed by European-American men and women at the Exposition to disrupt the racialized binaries used to exclude Chinese Americans from citizenship. The history of Chinese-American experiences at the Exposition extends beyond the oppositional conformity and gender malpractice of A Trip Through Chinatown into a more heterogeneous, layered history of Chinese Americans at the Fair wherein Asian women transgressed dual cultural systems of gendered restriction to showcase their modern personas as public consumers and observers of the Exposition.

\section{Reconstructing Chinatown: Layered Disruption}

We being Chinese, are susceptible to pinches and hair pulling, while other persons pause and gaze upon us, very much in the same way that I have seen people gaze upon strange animals in a menagerie. -Sui Sin Far, "Leaves from the Mental Portfolio of an Eurasian." 118

Like the Fairground itself, the overall urban geography of Portland was imbricated with colonial agendas and imperial aspirations that moved in multiple directions. For his part, Seid Back disrupted the geography of the city of Portland by centering the city in Chinatown. His booklet, A Trip Through Chinatown appealed to a popular desire to extend touristic travel beyond the fairgrounds into an exploration of the

\footnotetext{
${ }^{118}$ Sui Sin Far, "Leaves from the Mental Portfolio of an Eurasian," in Ling and White-Parks, Mrs. Spring Fragrance, 219.
} 
rapidly growing and ethnically diverse city. At the time of the Fair, two independently operating Chinatowns - one made up of vegetable gardens and shanties, another in the city's central business district - thrived eighteen blocks apart in the city's downtown area. Like the Exposition, the more urban Chinatown on the Willamette River waterfront offered locals and tourists venues for urban amusements, ethnographic performances, and international commerce. Portland's Chinatown, as old as the city itself, had a historic reputation as a tourist destination. Harvey Whitefield Scott, the brother of Abigail Scott Duniway and editor of the Oregonian, wrote a history of Portland in which he remarked, of the city's Chinatown in the 1850s, "to strangers there is nothing more attractive than the Chinese quarter." ${ }^{119}$ Going against the grain of histories written about American Chinatowns, both on the West and East Coasts, Portland's Chinatown defies the characterization of Chinatowns as solely vice districts avoided by most white Americans until the 1920s. Instead, as Marie Rose Wong's study of Portland's Chinatowns revealed, Chinese Americans in Portland operated a variety of respectable and disreputable businesses, including one of the city's first theaters. Wong described Portland's Chinatowns as "non-claves" to distinguish Portland from other cities where Chinatowns developed as ethnic enclaves according to definable, often legal, boundaries that segregated Chinese from white Americans. ${ }^{120}$ As Scott showed, since its establishment in

\footnotetext{
${ }^{119}$ Harvey Whitefield Scott, ed., History of Portland Oregon with Illustrations and Biographical Sketches of Prominent Citizens and Pioneers (Syracuse, N. Y.: D. Mason \& Co., 1890). 437.

${ }^{120}$ Sociologist Ivan Light's portrayal of American Chinatowns as dangerous districts visited only by whites who were interested in consuming or eradicating vice until the 1910 s failed to account for local differences and overlooked migrations and communications that connected various Chinatowns. Indeed, his failure to include any Portland or Seattle Chinatown sources highlighted the blind spot of his study. Light's linear history argued that not until the end of vice could tourism flourish. Portland's Chinatown witnessed violence and housed opium and prostitution
} 
the 1850s, Portland's Chinatown existed as a loose entity, moving around and integrated into the downtown business district, albeit recognized as something distinct from the European-American community. "The buildings which they occupy are mainly of solid brick, put up in the first place largely by Americans but on long leases to the Chinese merchants and have been fixed over according to their convenience and ideas of beauty. They are intensely oriental in their general air, with piazzas of curved roofs, highly ornamented with yellow, white and vermillion paint, and paper globes and gewgaws," Scott wrote, revealing the early Chinese-American community's ability to sustain and assert Chinese cultural identities in a nation-state often hostile to their presence. ${ }^{121}$ Disruptions occurred from the margins and the peripheries of Asian-American Portland. Fairgoers whose appearances neither fit Back's mold of the modern Chinese who wore the "garb of the American" nor the kimonoed geishas featured on the Trail's Japanese Village participated in both consumptive and productive aspects of the Exposition. Like the so-called "wild" and "unreclaimed" Indians, Asian-Americans fairgoers presented a mixture of European and Asian clothing styles, languages, and consumer tastes. Their outward appearances confused the East-West binary to present inter-National, transnational, and decolonial social practices. Rooted in a local history of steady community growth, three generations of Chinese Americans living in Portland had access to the Exposition. Ranging in occupational and economic backgrounds, and at

establishments; however, Wong argued cooperation between Chinese Americans and the community at-large to eradicate vice and violence between 1880 and 1930 diminished their impact. Ivan Light, "From Vice District to Tourist Attraction: The Moral Career of American Chinatowns, 1880 - 1940," Pacific Historical Review 43, no. 3 (August 1974): 368 - 370, 381, 383; Wong, Sweet Cakes, Long Journey, 268, 198 - 201.

${ }^{121}$ Scott, History of Portland Oregon, 437. 
various relationships to China and Chinese cultural influence, Chinese Americans visited the Fair in families, as couples and individuals. Groups of local Chinese and Japanese Americans wearing a range of European and Asian clothing styles participated in the Fair's public consumptions that the director of concessions and admissions John A. Wakefield described as "attractions that will carry dignity, appearance and merit; that will be interesting, instructive and amusing...of the highest order and class possible."122 In their expressions of selectivity between European- and Asian- social practices, Chinese and Japanese fairgoers inscribed the urban landscape with representations of a local identity that challenged systemic and social exclusions of "Orientals" on the basis of their alleged cultural fixity. Between the local press and the Exposition's organizers, white Portlanders attempted to submerge expressions of intertwined East-West identities by displacing the modern labor and consumption of Chinese Americans into the Exposition's exhibition of the foreign and the picturesque.

The staging and narration of the "picturesque" at the exposition incorporated Asian populations of the West into the basic Orientalizing framework of the fair in order to advance the region's racial hierarchy, the dominance of the Anglo-American colonizers, and assign foreignness to the well-entrenched Chinese-American community. Harvey Scott's inclusion of Chinese Americans in the early history of Portland as important participants in regional, local, and urban development simultaneous established a racialized exclusion of Chinese residents as distinct from "the American" pioneer population, the Exposition ambivalently employed inclusive exclusion strategies to

\footnotetext{
122 “"Outside Trail'," Olympia Record, June 6, 1905; John A. Wakefield, “Attractions on the Trail," Lewis and Clark Journal 2, no. 6, December 1904, p. 9.
} 
mediate the city's largest and oldest non-European pioneer population. Local AsianAmerican mothers in attendance disrupted the dominance of white women in the performance of proper and modern womanhood. As mothers at the Fair, Asian-American women exhibited a capacity to cross cultural borders through purchasing power as modern consumers without mimicking the physical appearances of white women, and without supervision from social activists and missionaries, like that established over numerous Native-American fairgoers. Their experiences, like those of the "blanketed" Indians discussed in chapter one, silently disrupted the Exposition through unreadable and inarticulate expressions that haunt the history of the Exposition in the documents of their observers. Recovering the evidence of their attendance to disrupt the historical record further embeds the history of the Exposition, Portland, and the Pacific Rim into a more transnational space.

When Chinese and Japanese mothers attended the Exposition, local journalists described them as exhibits of Orientalness or in search of advanced civilizational training. The Oregonian featured a photograph of Chinese-American fairgoers engaged in commerce and leisure on the Trail alongside pictures of the Trail's paid performers. Juxtaposing "a bunch of Portland Chinese Doing the Trail" alongside images of the "Iggorrote Belle," the "oily Turk," the "Hindoo fortune teller" and the "Nez Perce brave," the article drew a visual correlation between Chinese-American residents the non-citizen performers of the Trail's exhibits. ${ }^{123}$

123 "Men from Every Clime at the Fair," Oregonian, September 24, 1905, p. 30. 


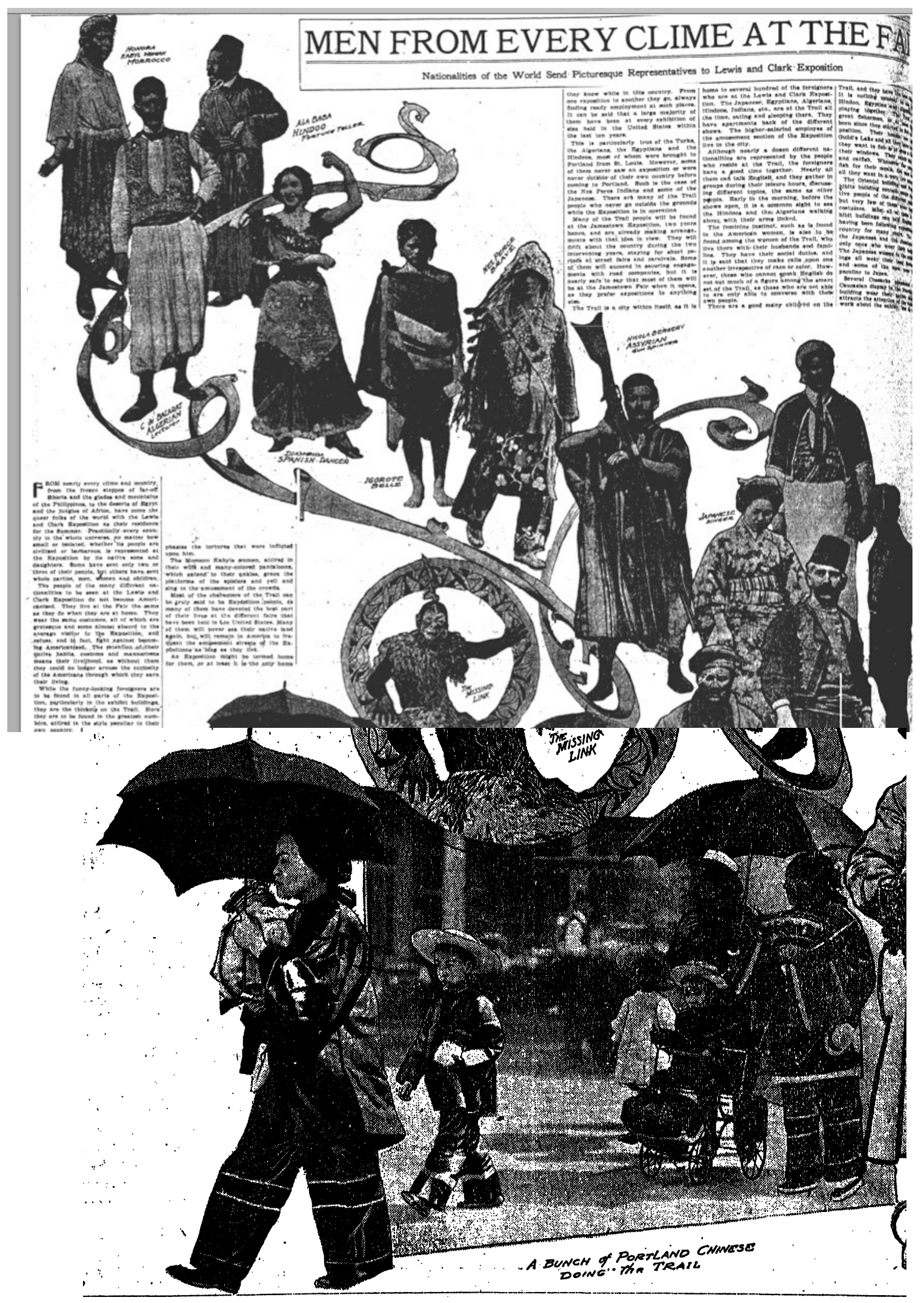

Images 2.5 - 2.6 "Men from Every Clime" and "A Bunch of Portland Chinese Doin' The Trail." 
Disrupting frames posed by the exposition, the unnamed Chinese Americans who appeared in the article - especially its most prominent subject, the Chinese-American mother - joined white Portlanders in the consumption of the Exposition's modern amusements and commerce. Also observing exhibits of modern science and technology as well as those that conveyed expressions of national, regional, and local heritage, they made individual conclusions about the spectacles they consumed.

An unscripted, gendered performance appeared in the photo spread, "Men from Every Clime.” The journalist highlighted Chinese men in skirts, pantaloons, and tunics easily misread as feminine garb. Further, the piece attempted to displace the "Portland Chinese" from the local American citizenry into a transient, foreign community representative of the "queer people of the world," that shared an identity as "Exposition people." Yet the Portland Chinese did not fit the article's framing of "the Japanese, Egyptians, Algerians, Hindoos, Indians, etc.," who were "at the Trail all the time, eating and sleeping there" as migrant laborers. As modern consumers and purveyors rather than laborers, and as Portlanders for at least two generations or more, rather than "funnylooking foreigners," Chinese Americans stood in contrast to the purposefully contrived and financially compensated identities represented in the Trail's official amusements. Instead they exhibited what Gyan Prakash identified as a destabilizing third "sight" by engaging observational power that whites wished to reserve for themselves and that nonwhite elites claimed for themselves as outwardly "modern" colonized subjects. The featured Chinese-American women subverted Seid Back's representation of the "respectable" Chinese-American woman who only entered the public sphere as a modern 
when wearing the "garb of the American." Dressed in traditional Chinese attire, in attendance as mothers, wives, and independently traveling women on the Exposition grounds, Chinese- and Japanese- American women disrupted mainstream stereotypes of Asian women as foot-bound or prostituted, and those that envisioned Asian-American communities as heathen bachelor societies. ${ }^{124}$ Asian women at the Exposition engaged in everyday acts of resistance to European-American social and political regulations through their clothing choices and their very presence in the United States. Asian Portlanders paired these "traditional" appearances with acts that conformed to "modern" EuropeanAmerican civilizational standards - like nuclear families, marriage, motherhood, and respectable leisure - everyday practices for which U.S. officials denied their capacity, and from which laws impeded them from performing. In their outward expression of a capacity to be wives and mothers and still be culturally inclined towards Asia, Asian Americans expressed independent conclusions and discreet observational agency that

\footnotetext{
${ }^{124}$ Page Act of $1875,43^{\text {rd }}$ Cong., $2^{\text {nd }}$ sess., Chap. 141, (March 3, 1875), U.S. Statues at Large volume 18, part 3 (1873 - 1875): 477 - 478; Wong, Sweet Cakes, Long Journey, 14. Local immigration officials questioned the veracity of many Chinese women's documents when they immigrated to the Pacific Northwest. The U.S. Page Act of 1875 predated the more encompassing Asian exclusion acts of the 1880s-1930s and set a higher - and ambiguous -standard for AsianAmerican women that in practice made it more difficult for many non-prostitute wives and female family members seeking entry and reentry into the United States. Local immigration inspectors scrutinized the appearances, behaviors, and bodies of Chinese women to determine whether they had entered for "lewd and immoral purposes," and many questioned the veracity of immigrant women's documented status as wives. Ostensibly an anti-prostitution law, the Page act of 1875 used moral grounds to justify the first race-based immigration exclusion act; it additionally gendered the terms of immigration to discourage the establishment of AsianAmerican communities in the United States. Like other Chinese exclusion laws, bribery, subjectivity, and inconsistency characterize the enforcement of the Page Act. The personal opinions of immigration agents and their susceptibility to taking bribes or denying entry to those without bribes left Asian women vulnerable to deportation on the basis of subjectivity and outward appearances.
} 
subverted the civilizational criteria used to justify legal obstacles to Asian family formation.

In their capacity to stare back at their white observers, to translate and consume the Exposition's exhibits of colonial science, Asian-American fairgoers resisted the Fair's tendency to exclude and segregate along a racialized and gendered East-West axis. Their disruption appear in white observers' scrambling to integrate nonwhite fairgoers into the Exposition's foreign spectacle. One Japanese mother in particular drew heightened scrutiny as she "dragged her youngsters around with her in spite of their feeble protests." The journalist alleged that the woman was "much too interested in the display of Yankee ingenuity and architecture to pay much attention to" her children. ${ }^{125}$ Displacing the woman into the realm of convalescence to Anglo-American cultural superiority and dubious motherhood, the journalist glossed over the fact that the Japanese family's visit occurred over three months prior to the Exposition's official opening and lacked many of the amusements, performances, music, and concessions of an operating world's fair. In this context, the half-built spectacle failed to inspire the awe of the Exposition that it did once it opened and instead left children bored and restless.

The Japanese woman stepped out of her frame to participate as an active consumer and spectator in the public, urban sphere. Not described as wearing Oriental clothing, she presumably dressed in a western style. As a mother with her children in tow and as an independent woman traveling through the urban, public sphere, she also cast doubt upon the prostitute-bachelor stereotypes applied to many Asian-American

\footnotetext{
125 "By the Thousands Visitors and Residents Go to Fair Grounds," Oregonian, February 27, 1905, p. 8.
} 
communities. The Japanese mother subverted Orientalist stereotypes that inscribed nonwhite women's participation in the public sphere with allegations of sexual promiscuity and prostitution. Textually, the journalist re-Orientalized her into passive subjectivity as an awe-struck observer of Anglo-American civilization, but in her silence, alternative possibilities abounded. As one historian of the Fair has put it, fairgoers of Asian descent likely "wondered about the real differences between the modern West and picturesque East," given Japan's recent military victory over Russia. ${ }^{126}$ Asian-American fairgoers, like most fairgoers, brought to the Exposition perspectives shaped by their own lived experiences and personal socio-political ideologies. When local Asian Americans went to the Fair, they engaged in one of the city's many opportunities to combine practices deemed Oriental and Western, traditional and modern.

White women also participated in touristic practices that blurred the boundaries of East and West. They could pay fifteen cents to visit "the Streets of Cairo," and once "in the midst of all that is Egyptian," they could pay an extra fee to ride a camel guided by "strangely garbed people."127 Meanwhile, the vaudeville composer, singer, and comedienne Mabel McCane performed in Oriental-style clothing at the Fair's most expensive concession, the "Carnival of Venice," an elaborate production of waterworks, gondolas, and hundreds of European ballet dancers in emulation of the canalled Italian city. The Carnival's theatrical emulation of Oriental womanhood differed significantly from the Fair's ethnic villages where nonwhite men and women, "clad in their native costumes, living in their own houses," performed "their modes of life, work and play...in

\footnotetext{
${ }^{126}$ Abbott, The Great Extravaganza, 43.

127 “Attractions on the Trail," Idaho Daily Statesman (Boise), June 6, 1905, p. 3.
} 
full view of visitors." McCane's domestic life remained private when she took the stage, whereas the daily domestic activities and labor of Asian and Native American women were on display for public consumption. In their taste for domestic products, clothing, and rituals that struck them as Native American or Oriental, white women identified with a European Orientalist fashion trend and bolstered their cosmopolitan sensibilities. World's fairs provided public places of international commerce where consumers could see and be seen, but they also added a pedagogical aspect to the sale and advertisement of foreign goods. Seen as artifacts from ancient societies, curios and ethnographic exhibits offered cultural knowledge without physical travel. Until the early-twentieth-century, white male elites had dominated the realm of global knowledge through imperial travel; however, through the expansion of the public, commercial sphere, and transportation technologies, women increasingly engaged in studies of human difference through real and virtual travel. ${ }^{128}$

\footnotetext{
${ }^{128}$ Hoganson, Consumer's Imperium, 186 - 187; Joan Jensen, "Women on the Pacific Rim," Pacific Historical Review; Raibmon, "The Practice of Everyday Colonialism," 194 - 220; Raibmon, Authentic Indians, 57 - 58.
} 


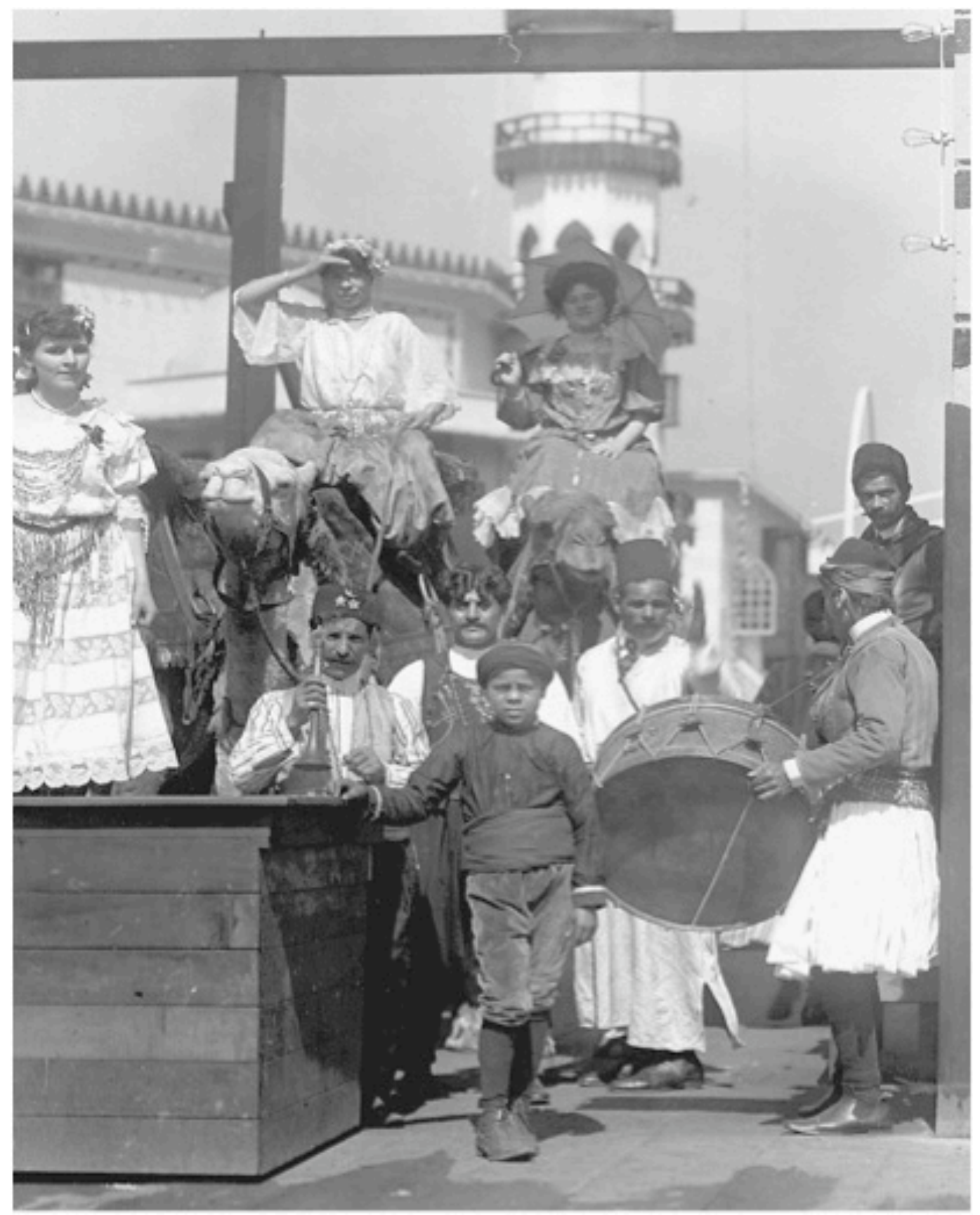

Image 2.7 "Camel Ride on the Streets of Cairo," Oregon Historical Society Research Library, OrHi 95010. The lines between nonwhite labor and white leisure were ambiguous on "The Streets of Cairo." 


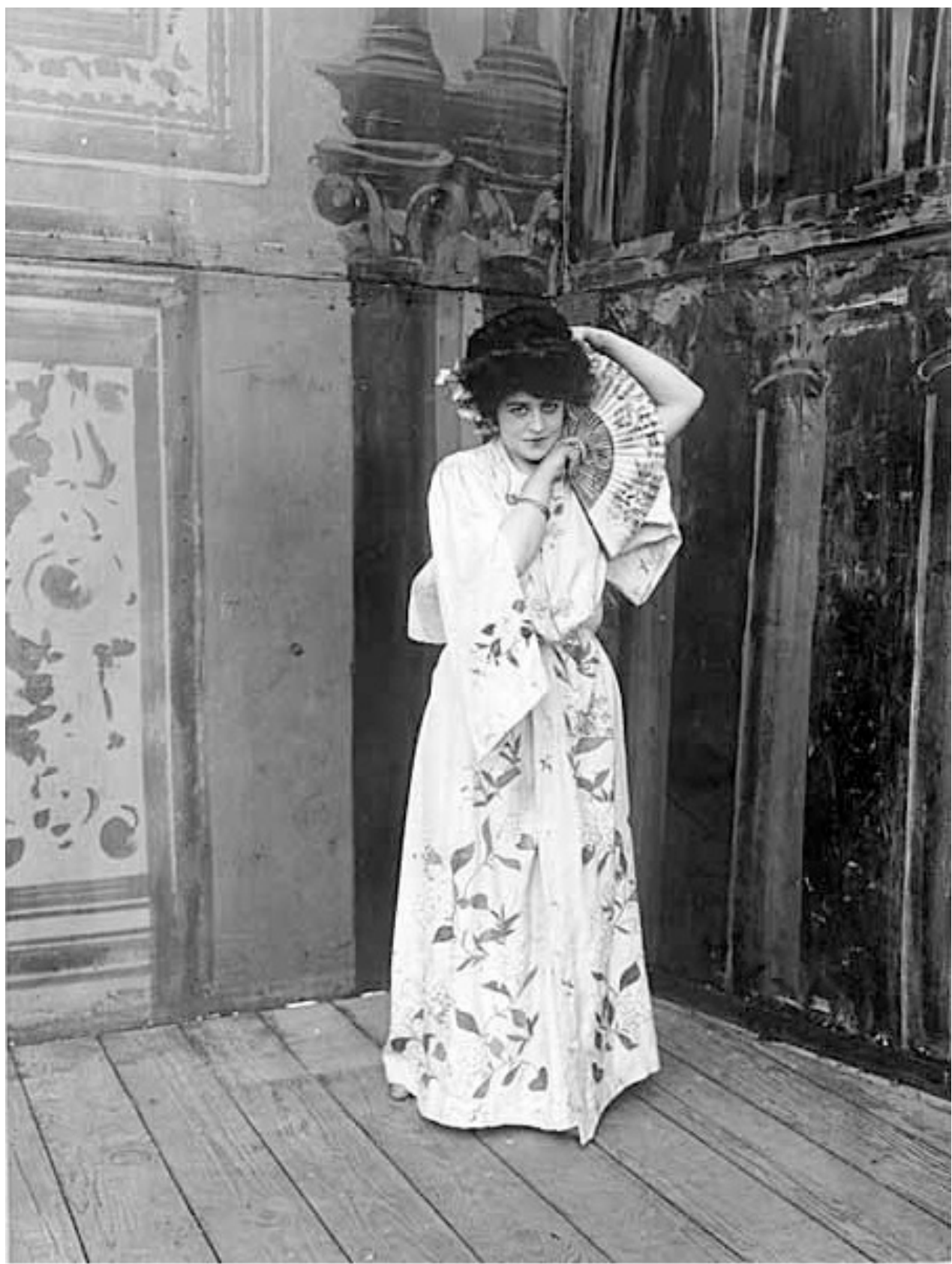

Image 2.8. Vaudeville Orientalism, Mabel McCane at the Carnival of Venice. University of Washington, PH Coll 391, box 1, folder 15.

Sites and sights of Asian labor and markets on the outskirts of the exposition further disrupted the fair's East-West binary. Chinese-American businesses, and public, cultural displays identified by Scott in mid-ninteenth-century Portland continued into the 
twentieth-century and disrupted the Exposition's stronghold on local amusements and international commerce. Nonetheless, Chinatown, an intercultural contact zone open to commercial and leisure activities, had to be delicately negotiated by all participants. The blocks along the city's waterfront housed the majority of Portland's Chinese and Japanese businesses, restaurants, shops, and residents, thus presenting a viable countersite to the Exposition. Chinatown attracted a range of locals and tourists seeking forms of amusement unavailable at the Exposition. In addition to its notoriety for illicit trades like prostitution and opium, Chinatown also appealed to consumers of ethnographic spectacle and international goods. Open for business and social events, vice and touristic pursuits, Chinatown's accessibility for white women - regarded as a group in need of protection or accompaniment in the public sphere - as part of an itinerary of "special entertainments" contradicts portrayals of American Chinatowns as too violent or perverse for middleclass American sensibilities. ${ }^{129}$ White explorers- flaneurs, gawkers, police, reformers, journalistic voyeurs, and border-crossers -of Chinatown often carried with them gendered and racialized perceptions of its residents and used them to conceive of their experiences in the district. Applying a language of conquest to white women's ethnographic tourism, one journalist described the urban excursions of the Ladies' Auxiliary of the Order of Railway Conductors during their time in Portland for the Fair, "Chinatown will be invaded during the stay of the visitors in Portland."130 Indeed, in addition to the observational and purchasing power exerted by white female tourists in Chinatown, at the Exposition, the white administrators of the city's local Chinese

${ }^{129}$ Light, "From Vice District to Tourist Attraction," 368-383.

130،'Holds Session Too: Ladies' Auxiliary O. R. C. Has Interesting Programme,” Oregonian, May 10, 1905, p. 10 . 
Missions, including female reformers, hosted a Chinese Sunday School on August $25^{\text {th }}$ at the Fair to exhibit their urban civilizing influence. ${ }^{131}$

Asians, Asian Americans, and Native Americans engaged in a range of social and economic practices at the Fair. While some, like Seid Back, used European-American language, social organizations, and texts to integrate nonwhite Americans into the history of community-building in the American West, others retold the history of the Exposition as disruptive fairgoers. Silenced by the epistemic violence of history-making enacted on the stages of world's fairs, and manifest in their archives, an account of subaltern women's experiences at the Fair appeared between the lines of their observers. The reports of local middle-class reformers, journalists, and police also constructed images of white working-class women to account for their variations on economic and consumer practices in the city. The following chapter extends the framework of disruptive labor and leisure into an analysis of the city's increasingly powerful coalition of middle-class female urban reformers and the growing population of single, working-class women whom the reformers closely monitored at the Fair.

131 “Chinese Sunday School Day, August 15, 1905,” Mss 1609, box 22, folder 4. 


\section{Chapter Three}

\section{Designs of Urban Maternalism, Disruptions of Rural Modernity}

As booth managers and demonstrators, waitresses, laundresses, policewomen, and prostitutes, white women worked a range of paid jobs unaffiliated with the suffrage campaign and distinct from nonwhite women's performative and productive labor at the exposition. As a group, white women were not explicitly exhibited, but they occupied certain forms of display space that objectified them both at the Fair and in its media portrayals. Their activities left a distinct imprint on the archives as well, a more scattered - even fugitive - presence in the voluminous Fair documentation, one thin indeed in photographic images compared to nonwhite racialized groups. White women across class boundaries engaged in the Fair along market lines, as employees, consumers, and customers. Indeed, by 1905, opportunities for paid labor and commercialized leisure at the Fair attracted an already well-established and street savvy population of young, working-class white and European-immigrant women working in the city of Portland in addition to hundreds of young, single women from out-of-town seeking employment and lodging or amusements during the Exposition.

As the previous chapters have shown, women's disruptions at the exposition often involved a series of boundary-crossing associations and displacements. This chapter uncovers the dynamic between a burgeoning local, middle-class women's urban reform movement and the city's increasingly large and fluctuating population of single, white working-class women. It argues that, while only intermittently visible in the official 
record of the Fair and frequently empowered to make choices about mobility and consumption unavailable to nonwhite women at the Fair, working-class women nonetheless figured as objects of maternalist attention and legal regulation in experiences similar to, yet distinct from, the socio-political and cultural dynamics discussed in the previous chapters.

Discourses of foreignness and savagery structured middle-class white women's authority over non-white women in Portland; meanwhile, narratives of vice and victimization swirled around white working women. Working-class women motivated a local urban reform movement to establish its moral and professional authority at the Exposition. Largely through the vice reports of Lola Greene Baldwin who rose to power as the city's first policewoman shortly after the Fair, this chapter first examines how Baldwin contested her own official exclusion from organizational power at the Exposition by asserting that the city's vulnerable working-class girls needed her maternalistic looking-after at the Fair. She relied on these women's non-normative behaviors and the perpetuation of class-based difference to substantiate her own inclusion amongst the city's citizen-elites. Second, this chapter uncovers additional layers of white women's paid labor that further disrupted attempts to define boundaries for and limit the mobility of white female laborers. Women who worked behind-the-scenes in their homes, factories, and offices, and who sold, displayed, traded, and bought products on the fairgrounds also contributed to the material displays and everyday needs of the Exposition with varied degrees of visibility, autonomy, and financial success. Their experiences, more articulate than those of nonwhite women, appear in the form of written 
correspondences with the Exposition's management and in a unique primary account written by rural Oregonian, Pauline Oleo McClay. Stories and advertisements in the press, in addition to Baldwin's vice reports, round out the somewhat flickering presence of working-class white women in the archives, providing evidence of their contributions to the Fair and complicating its history.

\section{Lola Baldwin and the Fair's "Vortex of Sin"}

A few women in Portland, who had shuddered over the fact that 700 young women disappeared during the World's Fair in Chicago...felt that some organized effort must be made to meet conditions sure to arise in Portland during the Lewis and Clark Exposition. ${ }^{132}$

As in the case of Native school children in the Exposition's official exhibits, reform-minded women had a stake in representing the city as needing regulation and uplift rather than depicting it as a pinnacle of civilization. The local Young Women's Christian Association (YWCA) created the Traveler's Aid Association of Portland to disrupt descriptions of the exposition as a "great educational and moral enterprise" attended by "people of intelligence, education, enterprise, and thrift." Seeing the Exposition instead as a magnet for vice and sexual exploitation, the YWCA mobilized a coalition of local women's clubs involved in settlement work and vigilante police work to

\footnotetext{
132 Jessie M. Honeyman, "President's Report," in "Report: Traveler's Aid Association of Portland, Oregon During the Lewis and Clark Centennial Exposition 1905," Mss 1609, box 101, folder 27; Donald L. Miller, City of the Century: The Epic of Chicago and the Making of America (New York: Simon \& Schuster, 1996), 506 - 507. Honeyman does not cite the source of her statistics, but historian Donald L. Miller wrote that hundreds of people went to the Chicago world's fair never to be heard from again. After the Fair, fifty of the alleged 700 missing women turned up in a brothel run by a man who one Miller described as the city's "most monstrous murderer."
} 
form the Traveler's Aid Association. Together, the intersecting organizations set out to eradicate the fair's "sensuous and lowest instincts." ${ }^{, 133}$ Urban reformers cast the city has having a potentially uncivilizing effect on women, especially those without families or husbands to usher them through work and consumption in the urban public sphere. These so-called women adrift were met with Traveler's Aid pamphlets, warnings, and physical representatives in the city's transportation depots and public spaces. On the fairgrounds, women could find rest, food, or employment in the YWCA Pavilion and restaurant. On the premise that official authorities lacked the capacity to understand- or turned a blind eye towards - young women working and traveling through urban spaces, and that middle-class white women were best equipped to guide and protect other women, the YWCA and the Traveler's Aid Association carved out professions in the city's police and judicial systems centered around the regulation and protection of working-class women and children.

Interrupting women's official exclusion from the Fair's managerial roles, representatives from social organizations like the local Women's Christian Temperance Union (WCTU), the Council of Jewish Women, and the Portland Women's Union joined women from other religious organizations and mission homes to create the Traveler's Aid Association and draw public attention to vice and its exploitation of womanhood on the fairgrounds. In its report on women's labor at the Exposition, the superintendent of the association, Lola Greene Baldwin, described a maternalist consciousness as a universal trait amongst the diverse clubs that had come together to form the organization.

133 "Columbia Court," Leslie's Weekly: Lewis and Clark Centennial Exposition Issue, p. 582; H.W. Stone, General Secretary of the Young Men's Christian Association (YMCA) to Henry W. Goode, June 14, 1905, Mss 1609, box 17, folder 3. 
“"Protection for Girlhood' is our motto," she announced, "We feel sure no woman's heart could refuse to help any case which has been taken up by us this summer.... women of every religious belief and those who are associated with none are all working in perfect harmony." The association prided itself on its cross-religious, cross-cultural concern for a group of women that they differentiated from themselves in terms of class, rural naïveté, or non-Anglo, non-Protestant European backgrounds. ${ }^{134}$ The reformers used the context of the Fair with its influx of people and expansion of opportunities for urban leisure and employment as a launching point from which they began to formalize and professionalize women's police work in Portland. Baldwin and another prominent local reformer, Millie Reid Trumbull, organized a juvenile court system to begin its operation the same month as the Fair. In her official but unpaid role as a probation officer of the juvenile courts, and as a meagerly paid agent of the Traveler's Aid Association, Baldwin focused on the uplift and discipline of girls and women regarded by the press and worried religious authorities as transient or "adrift." 135

\footnotetext{
${ }^{134}$ Middle-class women's groups began constructing industrial training homes and settlement houses in Portland's working-class neighborhoods in the late 1880s where they administered lodging, domestic training courses, citizenship classes, and job placement programs for workingclass and European immigrant women. In addition to the YWCA, the Portland Women's Union, the local Women's Christian Temperance Union (WCTU), the Home Training Association, the Portland Council of Jewish Women, the German Ladies Relief Society of Portland, the Unitarian Alliance, and the Presbyterian Ladies' Aid offered financial support and sent representatives to help the Traveler's Aid Association. Gloria E. Myers, A Municipal Mother: Portland's Lola Greene Baldwin, America's First Policewoman (Corvallis: Oregon State University Press, 1995), 2 - 5; "Report: Traveler's Aid Association of Portland, Oregon During the Lewis and Clark Centennial Exposition 1905," Mss 1609, box 101, folder 27; Lola Baldwin, “Superintendent's Report," in ibid.

135 Joanne Meyerowitz, Women Adrift: Independent Wage Earners in Chicago, 1880 - 1930 (Chicago: Chicago University Press, 1988); Myers, A Municipal Mother, 4, 13; Jeanne Madeline Weimann, The Fair Women, 13. Clubwomen in Chicago also established the juvenile court system to accommodate the enlarged urban population of the Chicago world's fair. Meyerowitz
} 
Urban reformers saw the Exposition as they saw commercialized leisure in the city more generally, as façades for corruption and vice. In her report, Jessie M. Honeyman, the president of both the YWCA and the Traveler's Aid Association, argued that "the masses of people gathered together, the glamour the brightness, the interesting exhibits, and the earnest discussion of modern problems, almost cast a veil over the other side, which invariably accompanies such occasions." Honeyman felt that the Fair's spectacle of technological, industrial, and moral progress veiled "the evil that lurks in darkness and abysses of sin and misery." ${ }^{\prime 136}$ This evil, the reformers argued, preyed on "foolish and unsuspecting" young women. Using data collected from previous world's fairs regarding the disappearance of young women and funds donated by the National Exposition Traveler's Aid Association in New York, Honeyman sent her local coalition of "white-winged messengers of safeguard" out to distribute over 10,000 "leaflets and dodgers of warning...far and near on the Pacific Slope, warning all young women and those who loved them of the dangers to be met with, and where to come for help." Honeyman conceived of the project as transnational, like the Fair itself, and extended the association's purview into Asia and the Pacific Rim, "printed matter was also sent to the Hawaiian Islands, and results came from some which reached China." ${ }^{137}$ Honeyman directed her reformist gaze towards the U.S. Empire in the Pacific and used previously

pulled the phrase "woman adrift" from a turn-of-the-century federal report on women and children wage earners in the United States.

${ }^{136}$ Honeyman, "President's Report," in "Report: Traveler's Aid Association of Portland, Oregon During the Lewis and Clark Centennial Exposition 1905,"Exposition Records, Mss 1609, box 101 , folder 27.

${ }^{137}$ Ibid; Meyerowitz, Women Adrift; Nina Mjagkij and Margaret Ann Spratt, eds., Men and Women Adrift: The YMCA and the YWCA in the City (New York: New York University Press, 1997). 
established networks of information established by the YWCA to spread word of women's protective services into other territories under U.S. influence.

As Honeyman and Baldwin well knew, the Fair existed in continuity and competition with the city's other venues of leisure and networks of commerce and transportation. The Traveler's Aid Association, with offices at train stations in cities throughout the country and agents on and off the fairgrounds, recognized this continuity. They included the Exposition as one locale within a broader survey of vice in the city, which propelled individual reformers like Baldwin into positions of prominence and power. After careful investigations of downtown Portland's businesses, lodgings, and employment postings for women, the association distributed lists of the city's "reputable" options for employment and leisure as well as those "disreputable" or "questionable" establishments they instructed women to avoid. In addition to printed material, reformers also physically accompanied and approached young women in the city. Responding to the movements of brothel proprietors and pimps that scoured the train station for unaccompanied women in search of jobs and lodging, groups of reformers patrolled train stations and other transportation depots and public places looking to thwart "organized efforts for the destruction of young women." The reformers, however, subjected the unaccompanied women to a different "organized effort" that restricted their ability to travel independently under the premise that a young, single, working-class woman lacked the capacity to look "out for her own affairs." 138

\footnotetext{
${ }^{138}$ Baldwin, "Superintendent's Report," in "Report: Traveler's Aid Association of Portland, Oregon During the Lewis and Clark Centennial Exposition 1905," Mss 1609, box 101, folder 27.
} 
Baldwin formalized and facilitated the work of the local Traveler's Aid Association, a branch of the larger national organization founded in New York, by establishing official alliances with the municipal police and courts, as well as the district attorney and the business-licensing department. She ensured that reformers had a legal means of dealing with illicit behavior at the Exposition through the city's juvenile court. As a juvenile probation officer, Baldwin processed many "little girls who were brought here to dance, sing or act, either in concert halls or at the Exposition" through the legal system. Her reports enumerated the association's success and its multiple forms of protection, "1,600 women and children assisted in Travelers' Aid office...60 penniless children and girls sheltered...400 girls directed to safe lodgings...45 girls rescued from perilous places, expenses paid and sent home." Perilous places included brothels and strip shows, dance halls and shooting galleries, but Baldwin regarded any use of women's bodies to attract male customers or observers - including women riding on floats in parades - as inappropriate forms of labor and consumption. For Baldwin, the jobs offered to unskilled single young women at the Fair and in the city often involved a degrading self-commodification. The association approached all job offerings as potentially "spurious," including those for waitresses, domestic workers, and cashiers, and they regarded venues like massage parlors and fortune-teller houses as disguises for vice operations. ${ }^{139}$

Baldwin's investigations during the Exposition carried the threat of a bad review and the possible nullification of business licenses, which downtown merchants hoped to

\footnotetext{
${ }^{139} \mathrm{Ibid}$; Myers, A Municipal Mother, 31, 56.
} 
avoid given the city's enlarged consumer base. Vice patrols of venues located off the fairgrounds prompted official investigations of amusements on the Trail that featured dancing women. Baldwin and her agents uncovered "organized efforts for the destruction of young women" in lodging houses, saloons, restaurants, and other venues of entertainment that employed young women to attract a male clientele. Deemed an "Outlaw Trail," the area immediately surrounding the fairgrounds housed cheaper and less-regulated shopping, eateries, and shows. The association's discovery of "one of the worst shows ever known...located almost at the entrance to the Exposition grounds," highlighted the inability of the Fair's official organizers to fully regulate the expanded sphere of vice brought about by the Fair. Portrayed as "an obscene muscle dance, too vile for description," the "Girl in Blue" additionally sparked a debate regarding acceptable forms of white women's performative labor on the stages of the Exposition. One journalist compared the dances performed on the Trail's "Streets of Cairo" to the "Girl in Blue," and others protested the "Gay Paree" concession on similar grounds, calling into question the moral character of the Exposition and portraying urban amusements as sexually exploitative. ${ }^{140}$

Assertive, consumerist behavior by youthful white women drew the suspicious gaze of urban reformers. The Traveler's Aid Association placed many young women who registered in their office under surveillance. A network of police detectives and settlement workers monitored women's activities in the city. The Association loosened or

${ }^{140}$ Baldwin, "Superintendent's Report”; “'Outside Trail' is a Noisily Diverting Feature of the Portland Exposition," Olympia Record (Olympia, Washington), June 6, 1905, p. 1; "To Investigate Gay Paree, Municipal Judge Hogue Orders Inspection of the Show," Oregonian, June 23, 1905, p. 8; H. W. Stone to Goode, June 14, 1905, Mss 1609, box 17, folder 3. 
heightened its scrutiny according to women's amenability towards the reformers' standards of proper feminine behavior. When they provided "Lizzie" with a job as a waitress and a room in a reputable boarding house, for example, the Association "watched her carefully to see if any further attempt was made to allure her." In order to "study" Lizzie, Baldwin "secured a room adjoining hers" to house a detective who "watched her for some time." The detective reported back to Baldwin "that the girl was alone and conducting herself properly," and the Association "relaxed in vigilance, feeling we could trust her." Lizzie's subsequent choices, however, frustrated their moral directives, "We next heard of her working in a cheap boarding house," Baldwin wrote. ${ }^{141}$ Lizzie returned to the Traveler's Aid office in search of legal aid when her employer at the boarding house accused her of theft. "Up until this time Lizzie had considered herself capable of looking out for her own affairs, but after all these experiences she asked us to manage for her," Baldwin concluded, confirming Lizzie's ineptitude as an independent woman in the city. When Lizzie and other young women who seemed most susceptible to the "vortex of sin" resided in the city's settlement homes they became "wards" with a "mistress" to monitor their behavior. Under closer supervision, Lizzie, her mistress reported, was "never out nights, and is doing excellent work."142 Baldwin distinguished between Lizzie's work in the boarding house and the job provided to her by the Association on moral and practical grounds. Daytime wage labor in venues deemed appropriate offered stability and protection that work in the vice trades lacked. Lizzie's initial evasion of the Association's surveillance and employment, however, suggested

\footnotetext{
${ }^{141}$ Baldwin, "Superintendent's Report."

${ }^{142}$ Ibid.
} 
that other factors led her away from the Association. Insufficient wages, disinterest in the work, discontentment with limited mobility, or some combination of any of these factors may have impacted Lizzie's decision to abandon their services.

The Traveler's Aid Association and the YWCA felt that through specific forms of work, young women would receive the training necessary to become good wives and mothers. Indeed, reformers envisioned the well-protected single white woman as eventually leaving work in the public sphere entirely for a life of domestic pursuits; they invested in marriageability. Baldwin described a "poor, motherless girl, needing the help, encouragement and guidance which no one in the world can give except a true mother." Thanks to the Association's maternalist influence and the girl's adherence to their moral order, she eventually got "married and is keeping house, as happy a little wife as any in Portland." Whether keeping women at home and alone at night, or sending them back to homes from which they had run away, Baldwin hoped to counter conduct that "would forever keep the girl from regaining her womanhood." ${ }^{\prime 43}$ The Traveler's Aid Association geared their own maternalist impulse towards producing good wives and true women.

In addition to monitoring women's work situations, urban reformers also monitored women's consumer and leisure practices in an effort to curb frivolous spending. Heterosocial urban leisure developed in the United States at the same time as and in a large part because of white working-class women's entrance en masse into the public sphere as wage-earning consumers. ${ }^{144}$ Baldwin considered irresponsible

\footnotetext{
${ }^{143}$ Ibid. In her report, Baldwin described a close personal connection with the girl and remarked that she attended the wedding.

${ }^{144}$ Kathy Peiss, Cheap Amusements: Working Women and Leisure in Turn-of-the-Century New York (Philadelphia: Temple University Press, 1986), 6 - 8.
} 
consumption a significant factor in working-class women's propensity to "fall into" prostitution. Women like "Lydia S... a country girl who came to Portland to see the Fair," appeared in Baldwin's reports. Lydia lacked "a means to go home, as she had spent all her money" on "many foolish purchases." eateries, and concessions, female consumers became part of the Exposition's spectacle.

A song written for the Fair entitled "Souvenir Sue" illuminated a perceived risk of a mixed gender marketplace. Unlike the financial problems described by Baldwin, the song portrayed women's consumption as a danger to men. The song began, "No doubt you all went to the great Portland Fair... while you were out there, you have surely met 'Souvenir Sue.' The building called 'Liberal Arts' was her graft, where liberal guys blew their cash." In contrast to portrayals of selfless womanhood demonstrated elsewhere on the fairgrounds, Souvenir Sue expected compensation in exchange for her affection. "She worked all the stands...and she worked them 'good,' too... she sought souvenirs, and she broke many hearts." Despite her shopping-induced promiscuity, the song's narrator asked Sue to marry him, "I've asked for the hand of this damsel, so dear - I want to keep as a love souvenir - for I can't resist her, and neither could you." In a final twist, the previously conniving Souvenir Sue became a souvenir herself, an object to be bought by the male breadwinner. ${ }^{146}$

\footnotetext{
${ }^{145}$ Lola G. Baldwin, "Superintendent's Report."

${ }^{146}$ M. Murdoch Lind, "Souvenir Sue," composed by Geo L. Spaulding (Chicago: Will Rossiter, 1905).
} 


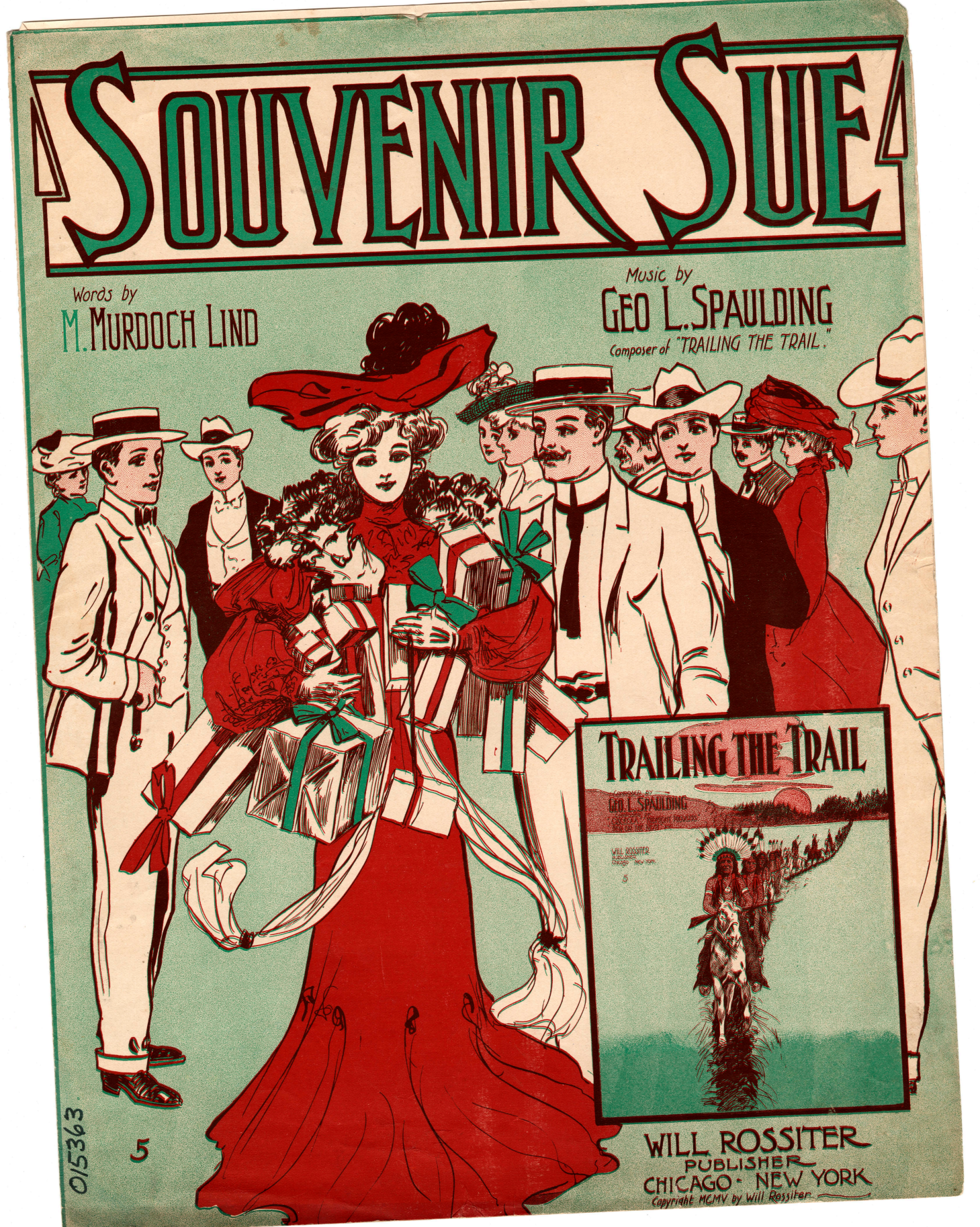

Image 3.1 "Souvenir Sue." Observed by many men, the fictional Souvenir Sue took advantage of the attention to meet her consumer desires. 
By identifying acceptable places for women to work and live, the Traveler's Aid Association hoped to curb women's deviant sexual and consumer habits. They found service industry jobs for women that would allegedly enhance their domestic skills without exploiting or despoiling their bodies. The Traveler's Aid office sent many women to work at the fair's YWCA Pavilion and restaurant. Described as a place of "rest and comfort" meant to resemble a "Swiss chalet," the Pavilion gave urban reform a quaint physical presence on the fairgrounds. The impromptu woman's building at the Exposition, however, disrupted the organizer's decision to deny women's requests for an official Woman's Building. The YWCA Pavilion served a number of purposes. It headquartered the Traveler's Aid Association, and numerous women's clubs hosted luncheons and meetings in the pavilion throughout the Exposition's run. On a daily basis, the building offered the comforts of home to fairgoers, including cots, restrooms, childcare, food, and lounges, the proceeds of which funded the construction of a permanent YWCA building downtown. ${ }^{147}$ To highlight the modern nature of women's domestic work, the restaurant served food prepared by women trained in local domestic science schools. Female politicians, teachers, and reformers from throughout the Pacific Northwest rotated the roles of hostess and dining room supervisor, and the young women recruited through the Traveler's Aid Association worked as waitresses at its restaurant. As historian Abigail Markwyn observed of the Y.W.C.A. building at the 1915 San Francisco world's fair, "the decision to combine service with exhibits showed a canny

147 "Review Good Work: Annual Business Meeting Held by Y.W.C.A," Oregonian, January 12, 1905, p. 10; "Place of Rest and Comfort: Y.W.C.A. Exposition Building," Oregonian, June 8, 1905, p. 10. 
understanding of how best to use the space the fair offered." ${ }^{148}$ The superintendent of the Portland Y.W.C.A. building, "Miss Constance McCorkle" exemplified the reformers' ability to surpass their official exclusion and use the Fair's space to exhibit and promote women's service work in the city. McCorkle presented her speech, the "Betterment of Women in the Cities," at the city's "Civics Conference" held from August 14-19 on the fairgrounds. ${ }^{149}$ The conference, promoted as an opportunity for "local men...to take part in the discussions," featured McCorkle as the lone female speaker. McCorkle "told of the trials and temptations of the ordinary young working girl alone in the city; of the dull and dreary life she was forced to follow," and argued that "women more happily situated" were capable of rescuing the working girl. By extending "the hand of encouragement" women like McCorkle proposed they could "assist their toiling sisters to a higher and better life." McCorkle voiced the kinds of "uplift" assumptions characteristic of missionary and outreach work domestically and overseas. ${ }^{150}$

\footnotetext{
148 "Y.W.C.A. Building Attracts," Oregonian, June 10, 1905, p. 10; Markwyn, "Encountering 'Woman' on the Fairgrounds," 178. Adelia B. Scott, a county treasurer from Idaho served as hostess both in the YWCA building and the Idaho building, and "Mrs. Anne Zoe Crayne," a woman described as a "preceptress" of a school in Weston, Oregon served as the head of the dining-room, another weekly rotated position in the building.

149 "The Lewis and Clark Conference on Civics Program," August 14 - 19, 1905, Mss 1609, box 99 , folder 8 .

150 "Life Intensified in the Cities," Oregonian, August 16, 1905, p. 10.
} 


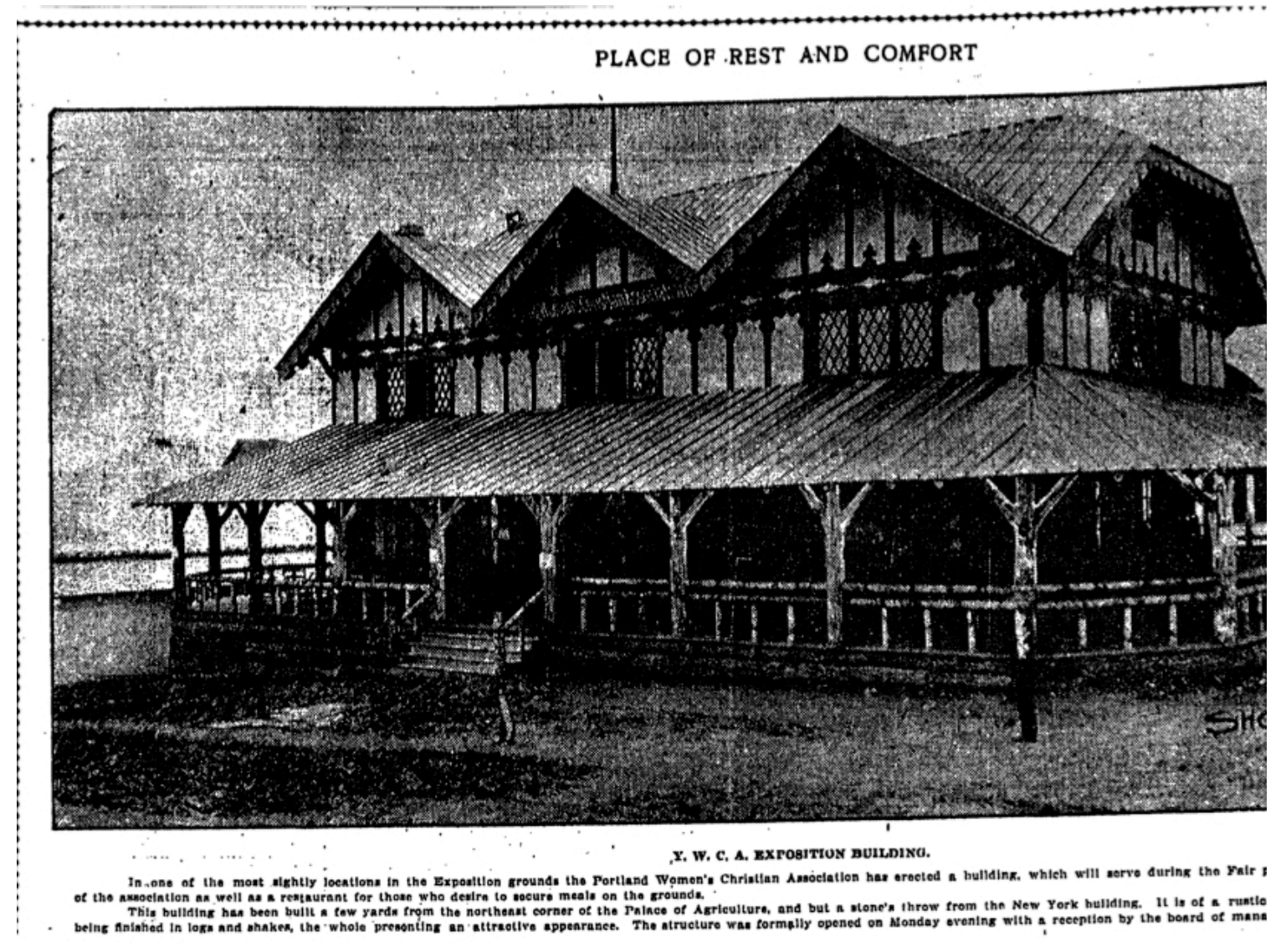

Image 3.2 "Place of Rest and Comfort." The caption identifies the building as "one of the most sightly locations in the Exposition grounds....built a few yards from the northeast corner of the Palace of Agriculture, and but a stone's throw from the New York building."

The press mediated the clubwomen's portrayal of women's work at the pavilion with representations of the traditional and domestic origins of their work. "Young women from Western Schools Do Domestic Duty at Young Women's Association Building - A Delightful Resting Place" one headline in the Oregonian announced. The article described the uniforms worn by the restaurant's employees as "Quakeress costumes" and reported that the women, "the managers of the enterprise say, make excellent domestics." The journalist confined "college girls" to roles as "domestics" whose "duties" provided the public with the comforts of home - food, rest, childcare. Rather than acknowledge 
their status as wage earners, the description of the YWCA employees instead framed women's paid labor in the public sphere as an extension of their unpaid domestic responsibility. ${ }^{151}$ Sensationalist stories of young working-class women succumbing to the "vortex of sin" and reports of "uplifted" women saved from the vortex obscured the voices of working married women and mothers, and women who traveled alone without the assistance of reform organizations. ${ }^{152}$

\section{A Subaltern Voice: Working Class and Rural Women Respond to the Fair}

'Experienced young lady wants position as cashier, city or Fair; charge of booth or other good position.'

'Wanted by a colored woman - Washing, ironing or any kind of day's work.'

'Two young ladies would like to work at the Fair grounds; one piano-player, one violin.'

'Wanted - Position at Fair Grounds by experienced lady; references.'

'Japanese woman wishes situation at housework or take care children.'

-“Situations Wanted - Female," Oregonian, May 28, 1905.

Working-class women often questioned the scrupulousness of the Fair's male employers when they asserted themselves as undercompensated laborers rather than

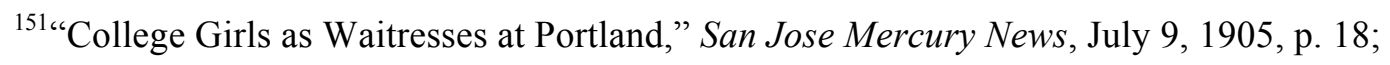
Meyers, Municipal Mother, 12 - 13. The article describes fifteen women from various Oregon universities, including the State University at Eugene, the Corvallis Agricultural College, Pacific University in Forest Grove, Willamette University in Salem, and the State Normal School in Monmouth. The building included a nursery and a playroom with a "playhouse where the youngsters may enjoy themselves while their mothers take in the fair."

${ }_{152}$ Pascoe, What Comes Naturally, 86. Newspaper reports on urban vice had a similar effect as interracial marriage dramas that also appeared in the press at the turn-of-the-century. As Peggy Pascoe put it, stories of prohibited sexual behavior "functioned by endangering marriage - and the respectability, property, and civilized values that were attached to it." 
accepting the domestic nature of women's work as an excuse for lower or withheld pay. A typical response to women who inquired directly about finding jobs at the Fair came from President Goode's secretary who informed women that work must be secured "on the ground," and warned that "if you come in hope of securing a situation of any kind, it must be entirely at your own risk, as the Exposition Company can not assume any responsibility in such matters." ${ }^{153}$ Even when they did find work, women experienced difficulties acquiring sustained employment or securing compensation for their labor. One such woman, Mrs. C. L. Ostrander, suspended her regular job to help with the Fair's laundry. Ostrander wrote directly to President Goode when her private contractor refused to pay in full. In her letter, Ostrander reported that she had been guaranteed $\$ 21.00$ for washing 150 pairs of trousers a week, but that "the work was so heavy I had to employ a woman to help me. (giving her half) we both worked very hard." As opposed to the agreed upon \$21 per week, her employer, “Mr. Davison," paid her \$20 for three weeks of work, which she was to split with her assistant. Ostrander, finding $\$ 20$ not "enough for two persons three weeks work," submitted a billing to Davison for \$33. Rather than paying Ostrander, Davison accused her of coming up short thirty-eight pairs of pants and told her she "did not earn the money." Davison reneged on the original contract and paid Ostrander twenty-five cents per pair of pants and five cents per "cap cover." In a final plea, Ostrander asserted to Goode, "I am a poor woman and cannot afford to lose so much. It cost me over $\$ 5.00$ per month to deliver the goods. Will you please give this

\footnotetext{
${ }^{153}$ Lola C. Owens to H.W. Goode, June 9, 1905, box 12, folder 13; Secretary to the President to Lola C. Owens, June 1905, in ibid.
} 
your kind attention. I can give you some of the Best People of Portland for references as to my truthfulness and Honesty.",154

Working as a married woman and under an informal contract -though she might have been a widow -increased Ostrander's risk of being defrauded. For both single and married women, employers often assumed that husbands or fathers shouldered the bulk of women's finances, and that women's work provided women and children with extra "pinmoney" to buy incidental or luxury goods. The 1900 U.S. Census, however, provided statistical evidence to the contrary. Most unmarried working-class women who participated in the Census lived alone and supported themselves, and most married women polled either worked as the primary wage-earner in their household or contributed most of their wages to support their families. Until 1913, when Oregon passed the country's first minimum wage law, women were viewed as temporary workers with fewer financial needs. Their wages failed to fully compensate for their labor, and as a result hardly met their personal and family's economic needs. ${ }^{155}$

Ostrander asserted herself directly as a laborer, but also as a booster and consumer by sending her letter on stationary featuring the "Lady Progress" seal that bought as a souvenir of the Fair. She presented a description of herself as both desperate and

\footnotetext{
${ }^{154}$ Mrs. C.L. Ostrander to Henry W. Goode, September 19, 1905, Mss 1609, box 12, folder 13; Secretary of the President to Ostrander, September 1905, in ibid. In response to Ostrander, President Goode's secretary directed her to take her claim to the proper bureaucratic office where, once filed, it would be investigated.

${ }^{155}$ Janice Dilg, “'For Working Women in Oregon,': Caroline Gleason/Sister Miriam Theresa and Oregon's Minimum Wage Law," Oregon Historical Quarterly 110, no. 1 (Spring 2009): 113; Judith A. Baer, The Chains of Protection: The Judicial Response to Women's Labor Legislation (Westport, Conn.: Greenwood Press, 1978), 22; United States, Bureau of the Census, Monograph no. 9, Women in Gainful Occupations, 1870 to 1920 (Washington, D.C.: U.S. Government Printing Office, 1929).
} 
respectable, to which she adjoined pride for the Fair and the city through her consumer loyalty and associations with the Best People of Portland. Her work and its lack of compensation reflected the relatively unregulated nature of women's labor and sheds light on another avenue of exploitation. ${ }^{156}$ Rather than doing paid, public labor (deemed masculine) or unpaid, domestic labor (deemed feminine), Ostrander's labor intermingled elements of both allegedly distinct spheres of activity.

Another claim written to Goode from A. Julia Kirker concerned her work as a stenographer for the Fair's administration. Although stenographers typically received higher wages than most working-class women, they also had to compete for jobs and negotiate for proper compensation at the Exposition. ${ }^{157}$ Kirker ultimately did not get the stenographer job for which she applied, but she had done some informal stenographic work for the Fair's administration and wrote to Goode requesting payment. Like Ostrander, Kirker performed unofficial labor that put her in a tenuous financial situation. Kirker was a well-known stenographer in Portland at the time of the Fair; she appeared in the advertisements of a local Smith Premier typewriter vendor, L \& M Alexander \& Co., which listed her alongside local businesses as one of the "Users of this Favorite Machine in the City of Portland." Regardless of her reputation, Kirker found it difficult to secure payment for her stenographic work. She appealed to Goode for the $\$ 12.65$ owed to her and provided an itemized list of the various transcriptions she had done for the Fair's board. Like Ostrander, Kirker presented her claim with deference: "if you think that I

\footnotetext{
${ }^{156}$ General Laws of Oregon, vols. 1903 - 1913 (Salem: State of Oregon), 180 - 182.

${ }^{157}$ According to a social survey published by a Catholic reformer in 1913, stenographers earned about $\$ 10$ a week, versus the $\$ 6.00$ per week paid to cannery workers. See Dilg, "For Working Women in Oregon,"'127, n. 59.
} 
ought not to have anything for it, let it go by...I leave it entirely in your hands and for you to dispose of as best you think." "158 The archival evidence of both women's experiences at the Fair begins with a report of unpaid or underpaid labor and ends abruptly with ambiguous responses from the administration that the conflicts will be investigated.

\section{Rural Modernity}

Part of the Exposition's multimedia expression of progress derived from its use and celebration of modern transportation technologies, the bravery of the white pioneer generation, and the noble savage image of indigenous people who graciously deferred to the stronger colonizing power. Transportation also proves an ambivalent domain, since it moves in at least two directions, to and from "home." Steamers and trans-continental trains carried out-of-towners to the Exposition and the Portland Railway's electric streetcars moved them through the city. Steamers also offered ten-cent rides down the Willamette River and the Exposition's Aeronautic Concourse hosted shows featuring blimps and "airships" that attracted large crowds. ${ }^{159}$ Scholars of twentieth-century women's history have noted how women's consumers choices around transportation proved to be a rich site for experimenting with new identities and mobility, and for creating new solidarities or establishing independence in the public sphere. ${ }^{160}$ While this

\footnotetext{
${ }^{158}$ A. Julia Kirker to H. W. Goode, April 1, 1903, Mss 1609 box 10, folder 12; Advertisement for L\&M Alexander \& Co., in Elizabeth F. McDonald to Henry E. Reed (director of publicity) January 7, 1902, Mss 1609, box 93, folder 5.

${ }^{159}$ Abbott, The Great Extravaganza, 42, 58 - 59; T.J. Clark to Goode (balloon/airship), Mss 1609 , box 43, folder 38 .

${ }^{160}$ In addition to the previously mentioned works of Jensen and Hoganson, see Virginia Scharff, Taking the Wheel: Women and the Coming of the Motor Age (Albuquerque: University of New Mexico Press, 1992); Curt Connell, A Reliable Car and a Woman who Knows It: The First Coast-
} 
literature largely notes the power of elite women driving west in a kind of re-staging of the frontier drama, the Portland Exposition tells a more complicated story of modern mobility with less linear trajectories. One particular woman's account of travel to the Exposition blurred the boundaries drawn between the modern city and its rural hinterlands to show adaptations of and preferences for transportations and economic systems often regarded as pre-industrial. A travel diary written by forty-one-year-old rancher and home-school teacher Pauline Oelo McClay, who traveled from her ranch to the Fair in September of 1905 brings to light an independent travel experience unadvertised by modern transportation companies that decentralized the Exposition as the final, primary, or most desired destination. ${ }^{161}$

McClay devised a route to the Fair that involved numerous layovers and changes in mode of transportation, modes that grew increasingly modern as she traveled over 200 miles from her home, Elkhorn Ranch, located on the Oregon coast near Coos County to Portland. McClay did not conceive of her independent travel to the Fair as an individualistic endeavor. Instead, by writing an account of her journey, McClay hoped to bring the experience of travel and observations of city life back to her family and friends

to-Coast Auto Trips by Women, 1899-1916 (Jefferson, N.C.: McFarland \& Co., 2000); Georgine Clarsen, Eat My Dust: Early Women Motorists (Baltimore: Johns Hopkins University Press, 2008).

${ }^{161}$ At the time of the Fair, McClay lived on Elkhorn Ranch with her sister and brother-in-law, Harriet and George Gould and their nine children. She had traveled with the Goulds and four of their children from her hometown in Sonoma County, California in 1885. Known as 'Elo, McClay was the self-taught educator of her sister's children. Their ranch had a schoolhouse of its own and McClay held class for four hours in the morning before she and the children attended to their ranch and housework. Pauline Oelo McClay, "My Trip to the Fair," Oregon Historical Quarterly 80, no. 1 (Spring 1979), 50 - 65. This article is a reprint of the original diary entries written by McClay during her trip to the Exposition in September of 1905, which are found in "Pauline McClay Travel Diary, 1905 - 1917," Dairies and reminiscences collection, Mss 1509, Oregon Historical Society Research Library, Portland. 
who could not make the trip, speaking to a rural community of knowers and travelers as part of her project. McClay first traveled on horseback first to Allegany, and then to Riverside where she helped a friend harvest tomatoes and where she "spent a p[1]easant evening talking of the Fair." The following day McClay continued on horseback to Loon Lake where she visited with more acquaintances and surprised one friend and her children when she popped up in their cornfield. ${ }^{162}$ After two days in Loon Lake visiting several other friends, McClay caught a ride on the buckboard cart of her friend and mail carrier Jack Baker to Scotsburg where she stayed in a hotel. The next day she took a stagecoach to Elkton where she met her nephew Elmer McClay, who was also planning a trip to the Fair. She then "changed stages \& went on to Drain," where she visited more friends. McClay's extensive network of family and friends in rural Oregon allowed her to travel inexpensively across the hinterlands. In Drain, McClay marked her first expense, "paid $\$ 1.00$ for a meal \& bed." According to her diary, she left Drain in the middle of the night on a 2 a.m. train to Portland, where she arrived around 9 a.m. Once in Portland, she boarded "the Esmond hotel buss [sic] had a room there that night paid $\$ 1.00$ for it." McClay found the Portland hotel less appealing than the Perkins house, the hotel where she stayed in Drain, "there were electric lights \& an elevator in that house, here I have three flights of stairs to climb." In addition to modern amenities - or a lack thereof McClay paid attention to the city's infrastructural and technological development. "It rained some today," she wrote, "but the streets are so well paved there is very little mud." At the Exposition she remarked on one building's "perfect" ventilation system. "All

${ }^{162}$ Ibid., $52-53$. 
around between the wall \& floor, was a strong current of cool air, and I suppose the warm air escaped the same way at the top, making it perfectly pleasant although it was crowded full." ${ }^{\prime 163}$ McClay approached her lodgings and the city with a critical eye not as an awestruck bumpkin. The noisy Esmond hotel kept McClay awake all night so she immediately took her business elsewhere, and when an unreliable steamship operation delayed her return trip home, she expressed weariness and frustration with the city. After ten days in Portland, McClay's October $9^{\text {th }}$ diary entry read, “Didn't go any where much, don't know of any place to go. Can't sail until Thursday or Friday. Am getting tired of the way they talk about the boats sailing, they have set three different times for it to sail." ${ }^{\text {164 }}$ McClay framed her negative experiences not as detractions from the grandeur of the city, but as part of a consumer report from an unofficial travel writer wanting to relay an honest account to her readers.

In her choice of leisure activities and observations of the city, McClay expressed a mixture of maternalist and modern identity markers typically assigned to urban women. No hint of a country-girl naïveté punctuated McClay's consumer observations on the Trail. Describing the amusement strip as a "great place," McClay ultimately concluded:

It should have been called the 'Spiders den' There is every thing there to get people's money, about a hundred 'nickle in the slot' machines....About twenty places where curio's \& souvenir are sold, and so many candy stands and ice cream \& lemonade stands clear out to the Government Building you don't any more than get free of one before you are in reach of another. ${ }^{165}$

\footnotetext{
${ }^{163}$ Ibid., 56.

${ }^{164}$ Ibid., 53, 61.

${ }^{165}$ Ibid., 58.
} 
McClay largely dismissed the "spider's den" in favor of concessions with a maternalist character. Indeed, before she ever set foot on the fairgrounds, McClay visited two local orphanages where matrons led her on tours to watch the children. Feeling embarrassed and uncomfortable with her observational intrusion, McClay wrote, "The girls were in the bathing rooms, they looked cute in their dainty white under clothes, I felt that I owed them an apology for coming in at that time, the matron seemed to treat them like any thing on exhibition." Nonwhite children in the orphanages stood out to McClay, "there was a negro $\&$ chinese boy six years old working together $\&$ the chinese boy was scolding the negro boy pretty lively who said nothing, but did his best." ${ }^{166}$ Although McClay did not feel at ease with humans on display, she nonetheless made multiple observations of people whom she encountered that reveal her understanding of American identity as white and Protestant. On Sunday, McClay toured the city's religious services. "The house was packed," when she went to hear "a lady...speak on Christian Sciance [sic]." Her criticisms of the Catholic mass were sharp and racialized. After the Christian Science lecture she went to a Catholic mass, which she described as full of "mystery and foolish ceremony....The Priests sermon sounded like an indian chant." In addition to Catholics, McClay distinguished herself from the city's Asian-American residents. Of her excursion to the waterfront district, she wrote "I would not want to lodge here long there are to many foreigners. I ate yesterday at a Japanese Coffee house tho the people eating were all americans. I saw a fine looking Mexican on the street, he was selling trinkets, a

\footnotetext{
${ }^{166}$ Ibid., $53-54$.
} 
small occupation for so strong a fellow." McClay presumed a shared acceptance of a racially exclusive national identity with her audience. ${ }^{167}$

McClay traveled throughout the city, consistently displaying her identity as a consumer, trader, tourist, and as an enthusiast of civic affairs and urban pursuits. Her avenues of maternalist and intellectual inquiry included additional visits to the orphanage and the Fair, excursions to a "Babies Home," City Hall, a Salvation Army meeting, the Boys \& Girls Aid Society, the Post Office, and three trips to the library. Her leisure and consumer pursuits also transcended the fairgrounds into the Oaks amusement park, a zoo in City Park, and a dry goods store. One day she inadvertently responded to Baldwin's call to prevent against drifting women in the city when she accompanied "a Sweedish lady" to lunch. The woman told McClay that "she hated to go alone" and "insisted on paying for us." McClay kept in touch with the Swedish woman during her time in Portland. Through McClay's observations, the woman's own difficulty at the Exposition emerges. When the two women went the Fair together several days after their lunch they scoured the grounds for the Swedish woman's lost suitcases. ${ }^{168}$ McClay stayed busy during her time in Portland by visiting numerous sites of pedagogical and entertainment value. She additionally leveraged her experience forward into expertise, mobility, and profit. On her first day in the city, McClay referred to her work-related activities in the city, "did some trading and a good deal of running around, traded some at 'Jones'.,169

\footnotetext{
${ }^{167}$ Ibid., 58.

${ }^{168}$ Ibid, $59-62$.

${ }^{169}$ Ibid., 53, 59.
} 
When McClay finally boarded the "steamer Aliance" headed to Astoria and then North Bend, she had a toothache and the ship departed four hours late. ${ }^{170}$

'Elo McClay and Lola Baldwin left two largely divergent records of women at the exposition. Where Baldwin's account identified hidden threats that especially preyed on young rural women who traveled alone to find work in the city, McClay's provided an account of a rural woman savvy and confident in her travels to and through the city. While they shared a maternalist tendency in their focus on women and children, McClay, unlike Baldwin, did not victimize the women and children whom she encountered nor did she conceive of herself as their protector. Instead, she seemed to view the Fair and the city as a repository of experiences, information, sights, and opportunities that she could turn into opportunities to expand her authority in her family and in the marketplace. McClay expanded the sphere of her "trading" and enhanced her capacity to offer childhood education. McClay was hardly Baldwin's presumed frail victim, and it is striking that they shared an impulse towards female solidarity and companionship in the city and at the Fair. Where Baldwin directed her efforts towards a regulation of women's movements McClay sought increased mobility and public opportunities. The choices made by so-called women adrift highlight the ways in which individual choice, leading in a number of directions, proved to be the signal feature of women navigating the Fair. Neither easily reducible to harbingers of a new femininity nor to relics of the traditional, in their unpredictability and relative autonomy, working-class and rural white women disturbed the stereotypes and expectations of their observers.

${ }^{170}$ Ibid., 62. McClay occupied a compartment with another female passenger traveling with three children, and a woman in the neighboring room gave her some carbolic acid, which cured her toothache 


\section{Conclusion: Does the Quaint Disrupt?}

Some years after the Fair, 'Elo McClay returned to her travel journal and wrote on its title page, "This is quaint, Elmer, I wonder if I wrote it." ${ }^{171}$ Looking back on her trip to the Fair, McClay in a sense, curio-ed herself. Defined as unusual, out of the ordinary and tellingly - picturesque or old-fashioned, the quaint disrupted the Exposition. In retrospective, McClay applied a sense of unconventionality to her journey that she crosscut with qualities of obsolescence and banality. Disrupting expectations that the Fair would strike awe and admiration in all of its observers, McClay expressed feelings of being underwhelmed by the city and its modern pursuits. At the 1905 Exposition, elite observers assigned the character of quaintness to nonwhite and working-class fairgoers in order to quell their unconventional appearances and create a more comfortable viewing distance for themselves as spectators. Quaintness proved a fragile classification for the people and pressures that destabilized the Exposition's linear and exclusive presentation of modernity and progress. This thesis has uncovered a range of social, political, and economic practices within and also beyond the Exposition's scenes of the curious and picturesque in order to conceive of the Fair from perspectives previously overlooked by historians.

The Exposition boosted the coffers of its organizing elites and many of the city's business owners, transportation companies, and real estate agencies. As its designers had hoped, it propelled the city into the national limelight as an urban, industrial, and international center of trade and development. Legislation enacted in the decade

\footnotetext{
${ }^{171}$ McClay travel diary, Mss 1509.
} 
following the Fair affirmed the success of the Fair's maternalist and imperial interveners, namely Eva Emery Dye, Lola Baldwin, suffragists, and urban reformers. In a sense, the Exposition transformed their disruptions into a gendered and racialized model for women's roles in state and municipal politics, law, and social work. Suffrage passed in Oregon seven years after the Exposition in part because white women's organizations continued and expanded upon the tactics employed at the Fair. Strategies like mass campaigning and coalition building, for example, enabled suffragists to consistently put the question up for vote in the state. ${ }^{172}$ They staged more public appearances that attributed the modernity of the city to white women's social and professional advancement, and the appropriation of nonwhite women continued to be a major aspect of these performances. Excluded from the city's primary suffrage organizations, local African-American and Chinese-American women organized their own suffrage leagues in the 1910s, and were invited to attend - separately - events hosted by white clubwomen. Describing one "mixed dinner," the Oregonian proclaimed, "Race Lines Not Drawn at Suffrage Banquet," and framed the gathering as an international feat, "Portland Beats England," the journalist contended. ${ }^{173}$ The contradictory design of the local suffrage movement, of a racially segregated but universal womanhood, that white suffragists presented at the Fair and in the years that followed, ultimately resulted in the disenfranchisement of Chinese-American, African-American, and unassimilated NativeAmerican women once the law passed.

\footnotetext{
${ }^{172}$ Jensen, "Revolutions in the Machinery," 342.

173“"Chinese Women Dine With White," Oregonian, April 12, 1912, p. 16.
} 
Contrary to their appropriated identities, in spaces created by the ideology of universal womanhood and by the public nature of the Exposition, women of Chinese, Japanese, African, and Native-American descent disrupted the criteria of feminine modernity by destabilizing racialized restrictions on their participation. Appearing in clothing and family arrangements that contradicted Eurocentric criteria for modernity and countered cultural stereotypes, nonwhite men, women, and families disrupted the fairgrounds through "quaint" acts of consumption and labor. Through their bold assertions of rights to the consumer and observational opportunities claimed by white Portlanders, Chinese Americans and African Americans disrupted the city's municipal authority to arrest and expel them. The organized performances and literature of Seid Back at the Exposition attempted to give voice to an entire Chinese-American community, and as a result, largely erased women and unassimilated Chinese-Americans. Back presented a view of the Pacific Rim in which the U.S. nation-state and race still played a role in the formation of citizen identities. However, he relocated the American West in between two pioneer migrations rather than framing it as a terminus for a U.S. continental expansion and a jumping-off point into U.S. dominance in the Pacific Rim.

After the Fair, Baldwin received a police star from Portland's Mayor Harry Lane for having disrupted the proliferation of vice during the fair. As her biographer described, in 1907, Baldwin cited her work during the exposition when she "packaged herself as a three-year de facto member of the police department and lobbied the city to pay for her vice crime work." In another dog-related disruption, Baldwin challenged the exclusion of herself and her organization from an official status and public funds by comparing the 
city's budget for the dog pound to the small amount of money she requested for the protection of women and girls. By 1908, Baldwin successfully secured two paid positions for women in the police department. ${ }^{174}$ In her expanded and official role as the first municipally paid policewoman in the United States, Lola Baldwin succeeded in either prohibiting, or enhancing the supervision of cross-dressers, fortune-tellers, and masseurs who conducted business in the city. She additionally implicated Chinese-American men in the corruption of white womanhood. When state senator and future governor of Oregon, Albin Walter Norblad introduced a bill in 1919 to the senate that prohibited the employment of white women in businesses owned "in whole or in part by Chinese," Baldwin secured a vote in favor of the bill. ${ }^{175}$ The dependency of white Portlanders on Chinese-American labor and Chinese international trade in addition to the power of reputable Chinese-American social organizations prevented the bill's passage. The Oregon Voter deemed the issue an "international situation," and challenged Norblad and his supporters on racial and commercial terms, calling their actions discriminatory and unproductive for Pacific Coast businesses that endeavored "to get Chinese trade" and were "eager to participate in the benefits of oriental commerce." The reporter additionally observed of the senatorial debate, "no one contended that immorality among white women was confined to Chinese restaurants, and no one seriously argued that Chinese

\footnotetext{
${ }^{174}$ Myers, A Municipal Mother, 20 - 22. Women competed for the two spots in the "Women's Auxiliary to the Police Department" by taking the civil service exam. As superintendent of the division, Baldwin received a salary of $\$ 150$ per month, $\$ 35$ more than the salary of male detectives. Lucy May Sargent obtained the job of Baldwin's assistant clerk.

${ }^{175}$ Some of Norblad's opponents preferred House Bill no. 350, which proposed a "county boards of morals" as be a more apt regulation of downtown vice that would prevent against Chinese boycotts locally and internationally. "Chinese Investments Extensive," The Oregon Voter 16, February 22, 1919, p. $35-36$.
} 
restaurants as a class were any more subject to an immorality charge than white restaurants."176 Unexpected alliances emerged out of mutual interests in maintaining physical mobility and commercial fluidity in the public sphere even as gendered protectionism, and interracial conflict continued to influence laws and public life in Portland long after the Fair.

For many working-class women and young travelers, the temporary nature of the Exposition left them jobless or stranded in the city. The influence of middle-class reformers on laws pertaining to women's work, under the guise of protection, simultaneously made it more difficult for women to secure employment. The city continued to confirm maternalist reformers' constructions of proper public behavior by enacting a series of laws that regulated the work and leisure activities of working-class women and other Portlanders deemed deviant. Laws against cross-dressing, fortunetelling, and women's participation in jobs dominated by men - with the exception of the female municipal officers and authorities, of course - criminalized women's gender transgressions in labor and leisure activities. The city's minimum wage laws passed in 1906 continued to reflect the presumption that women either had or sought the companionship of a male breadwinner, leaving women with fewer employment options and lower wages than men. ${ }^{177}$ Baldwin's success depended on working-class women's persistent crossings of her borders of respectability. Women strategically worked around

\footnotetext{
176“White Help with Chinese,” ibid., March 1, 1919, p. 15.

${ }^{177}$ Myers, A Municipal Mother, 29- 33; Dilg, "“For Working Women in Oregon,"”97 - 98. Baldwin accused female barbers, masseurs, and fortunetellers of selling more than just haircuts, massages, and tarot readings. The protective labor laws of passed between 1903 and 1910 failed to address "women's poverty-level wages, gender-segregated occupations, and unsafe working conditions."
} 
Baldwin's borders in order to avoid arrest or having their business licenses revoked by appealing to the reformers' standards of proper feminine behavior. ${ }^{178}$

Native Americans in Portland continued to disrupt their portrayal as a dying race after the Exposition. While this study failed to find firsthand accounts to accompany the varied Native-American experiences at the Fair, the sheer variety of documented representations indicated lifestyles and identity-constructions that thwarted colonial and metropolitan authorities, that intermixed tradition and modernity, and that resisted or combined U.S. and tribal affiliations. ${ }^{179}$ Accounts of the Fair's "picturesque" NativeAmerican consumers, its "in-line" Indian school children, in addition to those of both unassimilated and civilized identities "unreclaimed" by federal Indian agents, exposed Portland as a place of twentieth-century Native-American migrations and settlement patterns. Native Americans at the Exposition highlight the necessity of including urban spaces in Native-American history as well as the necessity of including Native Americans in urban histories. The number of Native Americans living in Portland increased as former students from Oregon's Indian training schools, Reservation Indians, and Indians unaffiliated with government programs moved to the city in pursuit of seasonal and permanent work, settlement and travel. ${ }^{180}$ Julia Fratis, a former pupil at Chemawa, and

\footnotetext{
${ }^{178}$ Myers, A Municipal Mother, 30 - 31. Myers provided numerous accounts from Baldwin's vice reports of women in "masculine" jobs or clothing who avoided arrest by demonstrating their feminine qualities. For example, between 1909 and 1910, a musically-talented cross-dresser and a mother-daughter team of barbers who passed the inspection of Baldwin's undercover agent both avoided legal problems because their "moral" character outweighed their social deviance.

${ }^{179}$ For more on Native-American women in state and tribal politics, see Kay Reid, "Multilayered Loyalties: Oregon Indian Women as Citizens of the Land, Their Tribal Nations, and the United States," Oregon Historical Quarterly 113, no. 3 (Fall 2012): 392 - 407.

${ }^{180}$ Nicholas Rosenthal, Reimagining Indian Country, $36-41 ; 55-57$. Rosenthal has pointed out that the San Francisco world's fair and the burgeoning film industry of the 1910s instigated a
} 
her sister Martha moved to Portland in the 1920s, they did not seek domestic work in white homes as encouraged by Indian agents. Instead, they worked public jobs and became active in organized labor and protest. Julia Fratis joined the Janitors' Union and Martha Fratis joined a laundry union, and both marched in strikes. In her exit survey, Julia remarked of young Native-American girls she witnessed in the city, "the girls do not seem to seek the better things in life." ${ }^{\prime 11}$ Claiming the "better things in life" for NativeAmerican women, Fratis asserted a socio-political consciousness developed despite the influence of institutions and pedagogy that sought to keep her docile, and uncritical of her imposed racialized identity.

On her return trip to Elkhorn Ranch, 'Elo McClay again used numerous forms of transportation and made several stops to visit friends who exchanged the news of the countryside for her news of the city. Like her journey to the Fair, McClay's return trip home involved a mixture of social and work-related interactions. Continuing with an ambiguous approach to her own income and labor, she wrote "Lettie gave me $\$ 7.50$ at Allegany" and "L. has paid $\$ 14.50$ on her rent up to date, Oct. 10," in her list of expenses paid and earned, tallying additional income earned from letting out an unidentified lodging. During the last four days of her journey, McClay's brother-in-law met her in the town nearest their ranch where they canned tomatoes, secured wood to make a fence for her father's grave, made the fence, and started a batch of apple cider vinegar. For

significant migration of Native-Americans to California cities where many decided to settle. The number of Native Americans living in Portland continued to increase in the 1950s and 60s with the passage of the Indian Relocation Act that sought to further dissolve tribal affiliations and assimilate Native Americans by sending them away from Reservations into vocational programs and homes in cities and towns.

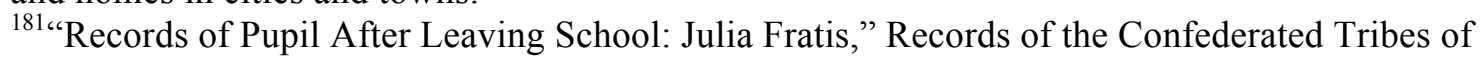
the Siletz, Mss 442, box 25, folder 6. 
McClay, travel did not simply represent modernity, but rather an intersection of modern and traditional transport, rural and urban sociability, domestic and public work. ${ }^{182}$ Her traveler's critiques disrupted the Fair's celebration of modernity through expressions of urban anxieties and weariness different than those identified by reformers. According to McClay's expenses, her most frustrating experience, the steamship ride home, was also her most expensive purchase, costing her $\$ 10$. The unreliable and uncomfortable ride cost McClay over twice as much as her other purchases, and over ten times as much as most. In her daily life, McClay continued to live what appeared in many ways to be a premodern lifestyle. She did not write of a desire for Portland's modern roads, buildings, or technologies in her travel log, and her ranch remained accessible only by horseback or by foot until long after she moved away in 1913. McClay continued to embellish and interweave her rural identity with modern amusement, knowledge, and travel. In 1915, she went to San Francisco to see the Panama Pacific International Exposition. McClay only briefly mentioned the experience in her journal, remarking simply that she spent three days at the Fair. Unlike her trip to Portland, when McClay went to San Francisco, she traveled primarily by boat and with her nephew and his family. She did not experience the opportunities for introspection and writing offered by independent travel during her trip to Portland for the Lewis and Clark Exposition. ${ }^{183}$

\footnotetext{
${ }^{182}$ McClay, "My Trip to the Fair," $64-65$.

${ }^{183}$ Ibid., 51; McClay travel diary, Mss 1509.
} 


\section{Bibliography}

\section{Primary Sources}

\section{Manuscript Material and Public Documents}

Annual Reports of the Department of the Interior. Washington, D.C.: United States. Office of the Commissioner of Indian Affairs, 1906.

Dye Family Photographs Collection. Org. Lot 1017. Oregon Historical Society Research Library. Portland.

General Laws of Oregon, vols. 1903 - 1913. Salem: State of Oregon.

Lewis \& Clark Centennial Exposition Records. Mss 1609. Oregon Historical Society Research Library. Portland.

Lind, M. Murdoch. “Souvenir Sue.” Composed by Geo L. Spaulding. Chicago: Will Rossiter, 1905.

McBeth, Kate C. The American Indian Correspondence: The Presbyterian Historical Society Collection of Missionaries; Letters, 1833 - 1893. Transcription. University of Idaho microfilm collection.

Pauline McClay Travel Diary, 1905 - 1917. Dairies and reminiscences collection. Mss 1509. Oregon Historical Society Research Library, Portland. Reprinted as Pauline Oelo McClay. "My Trip to the Fair." Oregon Historical Quarterly 80, no.1 (Spring 1979): 50-65.

Records of the Confederated Tribes of the Siletz. Mss 442. Oregon Historical Society Research Library, Portland.

United States Bureau of the Census. Women in Gainful Occupations, 1870 to 1920. Monograph no. 9. Washington, D.C.: U.S. Government Printing Office, 1929.

United States Congress. Oregon Donation Land Act. Ch. 76, sec. 4 - 5, 9 Stat. 496, 497 1850 .

United States Office of Indian Affairs. Rules for the Indian School Service. Washington, D.C.: Government Printing Office, 1898.

University of Washington Libraries. Special Collections. Lewis and Clark Exposition Repository. PH Collection 391. 
U.S. Statues at Large. Volume 18. Part 3. 1873 - 1875.

\section{Books and Journal Articles}

Dye, Eva Emery. The Conquest: The True Story of Lewis and Clark. Chicago: A.C. McClurg \& Company, 1902.

Far, Sui Sin. "Leaves from the Mental Portfolio of an Eurasian," Independent, January 21, 1909. Reprinted in Amy Ling and Annette White-Parks, editors. Mrs. Spring Fragrance and Other Writings. Urbana: University of Illinois Press, 1995.

Lewis, Meriwether and William Clark. The Journals of the Lewis and Clark Expedition. Lincoln: University of Nebraska-Lincoln Libraries Electronic Text Center, 2005. http://lewisandclarkjournals.unl.edu (accessed January 8, 2012).

McBeth, The Nez Perces Since Lewis and Clark. New York: Fleming H. Revell Company, 1908.

Scott, Harvey Whitefield, ed. History of Portland Oregon with Illustrations and Biographical Sketches of Prominent Citizens and Pioneers. Syracuse: D. Mason \& Co., 1890.

Sights and Scenes at the Lewis and Clark Centennial Exposition in Portland, Oregon: Very Completely Illustrating the Fair. Portland, Ore.: R. A. Reid, 1905. In Kiser Photo Company Photographs. Org. Lot 140. Box 11, Folder 22.

\section{Newspapers, Magazines, and Periodicals}

Idaho Daily Statesman (Boise)

The Independent (New York)

Leslie's Weekly: Lewis and Clark Centennial Exposition Issue (New York)

Lewis and Clark Journal: The Official Bulletin of the Lewis and Clark Fair (Portland)

Macon Telegraph (Georgia)

The New Northwest (Portland)

Olympia Daily Recorder (Olympia, Washington, also published as the Olympia Record)

The Oregonian (Portland) (also published as Morning Oregonian and Sunday Oregonian) 
Oregon Journal (Portland)

The Oregon Voter (Portland)

Evening News (San Jose, California)

Wilkes-Barre Times (Pennsylvania)

Women's Tribune (Beatrice, Nebraska)

\section{SECONDARY SOURCES}

\section{Books and Journal Articles}

Abbott, Carl. The Great Extravaganza: Portland and the Lewis and Clark Exposition. Portland: Oregon Historical Society, 1981.

—and William L. Lang. Two Centuries of Lewis \& Clark: Reflections on the Voyage of Discovery. Portland: Oregon Historical Society Press, 2004.

Anderson, Wanni W. and Robert G. Lee, eds., Displacements and Diasporas: Asians in the Americas. New Brunswick: Rutgers University Press, 2005.

Azuma, Eiichiro. Between Two Empires: Race, History, and Transnationalism in Japanese America. New York: Oxford University Press, 2005.

—. "Racial Struggle, Immigrant Nationalism, and Ethnic Identity: Japanese and Filipinos in the California Delta, 1930-1941." Pacific Historical Review 67, no. 2 (May 1998): 163-199.

Baer, Judith A. The Chains of Protection: The Judicial Response to Women's Labor Legislation. Westport, Conn.: Greenwood Press, 1978.

Bailey, Jennifer. "Voicing Oppositional Conformity: Sarah Winnemucca and the Politics of Rape, Colonialism, and 'Citizenship." Master's thesis, Portland State University, 2012.

Blanchard, Pascal, et al., eds. Human Zoos: Science and Spectacle in the Age of Colonial Empires. Liverpool: Liverpool University Press, 2008.

Blee, Lisa, "Completing Lewis and Clark's Westward March: Exhibiting a History of Empire at the 1905 Portland World's Fair." Oregon Historical Quarterly 106, no. 2 (Summer 2005): 232-253. 
Boisseau, T.J. and Abigail M. Markwyn, eds. Gendering the Fair: Histories of Women and Gender at World's Fairs. Urbana: University of Illinois Press, 2010.

Cahill, Cathleen D. Federal Fathers and Mothers: A Social History of the United States Indian Service, 1869 - 1933. Chapel Hill: University of North Carolina Press, 2011.

Clarsen, Georgine. Eat My Dust: Early Women Motorists. Baltimore: Johns Hopkins University Press, 2008.

Connell, Curt. A Reliable Car and a Woman who Knows It: The First Coast-to-Coast Auto Trips by Women, 1899-1916. Jefferson, N.C.: McFarland \& Co., 2000.

Dilg, Janice. “'For Working Women in Oregon,': Caroline Gleason/Sister Miriam Theresa and Oregon's Minimum Wage Law." Oregon Historical Quarterly 110, no. 1 (Spring 2009): 96-129.

Dubois, Ellen. "Woman Suffrage: The View From the Pacific." Pacific Historical Review 69, no. 4 (November 2000): 539 - 551.

Edwards, Louise. "Women's Suffrage in China: Challenging Scholarly Conventions." Pacific Historical Review 69, no. 4 (Nov. 2000): 617 - 638.

Frink, Brenda D. "San Francisco’s Pioneer Mother Monument: Maternalism, Racial Order, and the Politics of Memorialization, 1907-1915." American Quarterly 64, no. 1 (2012): $85-113$.

Heffernan, Michael and Carol Medlicot. "A Feminine Atlas? Sacagawea, the Suffragettes and the Commemorative Landscape in the American West, 1904 - 1910."Gender, Place and Culture 9, no. 2 (2002), 109-131.

Hoganson, Kristin L. Consumer's Imperium: The Global Production of American Domesticity, 1865-1920. Chapel Hill: University of North Carolina Press, 2007.

—. Fighting for American Manhood: How Gender Politics Provoked the SpanishAmerican and Philippine-American Wars. Yale University Press, 1998.

Hoxie, Frederick E. and Jay T. Nelson, eds. Lewis and Clark and the Indian Country: The Native American Perspective. Urbana: University of Illinois Press, 2007.

Jacobs, Margaret. "Breaking and Remaking Families: The Fostering and Adoption of Native American Children in Non-Native Families in the American West, 1880 1940." In On the Borders of Love and Power: Families and Kinship in the 
Intercultural American Southwest, edited by David Wallace Adams and Crista DeLuzio, 19-46. Berkeley: University of California Press, 2012.

Jensen, Kimberly. "Revolutions in the Machinery: Oregon Women and Citizenship in Sesquicentennial Perspective." Oregon Historical Quarterly 110, no. 3 (Fall 2009): 336-361.

Jensen, Joan M. "Women on the Pacific Rim: Some Thoughts on Border Crossings." Pacific Historical Review 67, no. 1 (Feb. 1998): 3 - 38.

Kal, Hong. "Modeling the West, Returning to Asia: Shifting Politics of Representation in Japanese Colonial Expositions in Korea." Comparative Studies in Society and History 47, no. 3 (July 2005): 507 - 531.

Kessler, Donna J. The Making of Sacagawea: A Euro-American Legend. Tuscaloosa: University of Alabama Press, 1996.

Lee, Shelley Sang-Hee. Claiming the Oriental Gateway: Prewar Seattle and Japanese America. Philadelphia: Temple University Press, 2011.

Light, Ivan. "From Vice District to Tourist Attraction: The Moral Career of American Chinatowns, 1880 - 1940." Pacific Historical Review 43, no. 3 (August 1974): 367-394.

Ling, Amy and Annette White-Parks, eds. Mrs. Spring Fragrance and Other Writings. Urbana: University of Illinois Press, 1995.

McLagan, Elizabeth. A Peculiar Paradise: A History of Blacks in Oregon, $1788-1940$. Portland, Ore.: Georgian Press, 1980.

Mead, Rebecca J. How the Vote Was Won: Woman Suffrage in the Western United States, 1868 - 1914. New York: New York University Press, 2004.

Merriam, Paul G. "The 'Other Portland': A Statistical Note on Foreign-Born, 1860 1910.” Oregon Historical Quarterly 80 (Fall 1979): 258-268.

Meyerowitz, Joanne. Women Adrift: Independent Wage Earners in Chicago, 1880 1930. Chicago: Chicago University Press, 1988.

Miller, Donald L. City of the Century: The Epic of Chicago and the Making of America. New York: Simon \& Schuster, 1996.

Mjagkij, Nina and Margaret Ann Spratt, editors. Men and Women Adrift: The YMCA and the YWCA in the City. New York: New York University Press, 1997. 
Morton, Patricia A. "National and Colonial: The Musée des Colonies at the Colonial Exposition, Paris, 1931.” Art Bulletin 80, no. 2 (June 1998): 357-377.

Myers, Gloria E. A Municipal Mother: Portland's Lola Greene Baldwin, America's First Policewoman. Corvallis: Oregon State University Press, 1995.

Newman, Louise. White Women's Rights: The Racial Origins of Feminism in the United States. New York: Oxford University Press, 1999.

Okihiro, Gary Y. Common Ground: Reimagining American History. New Jersey: Princeton University Press, 2001.

Olsen, Deborah M. "Fair Connections: Women's Separatism and the Lewis and Clark Exposition of 1905." Oregon Historical Quarterly 109, no. 2 (Summer 2008): 174 $-203$.

Parrenas, Rhacel Salazar. "'White Trash' Meets the 'Little Brown Monkeys': The Taxi Dance Hall as a Site of Interracial and Gender Alliances between White Working Class Women and Filipino Immigrant Men in the 1920s and 1930s," Amerasia Journal 24, no. 2 (1998): 115-134.

Pascoe, Peggy. What Comes Naturally: Miscegenation Law and the Making of Race in America. Oxford: Oxford University Press, 2009.

Patterson, Martha H. Beyond the Gibson Girl: Reimagining the American New Woman, 1895-1915. Urbana: University of Illinois Press, 2005.

-. The American New Woman Revisited: A Reader, 1894 - 1930. New Brunswick, NJ: Rutgers University Press, 2008.

Peiss, Kathy. Cheap Amusements: Working Women and Leisure in Turn-of-the-Century New York. Philadelphia: Temple University Press, 1986.

Pérez, Emma. The Decolonial Imaginary: Writing Chicanas into History (Bloomington: Indiana University Press, 1999.

Peterson del Mar, David. Beaten Down: A History of Interpersonal Violence in the West. Seattle: University of Washington Press, 2002.

Prakash, Gyan. "Science 'Gone Native' in Colonial India." Representations 40 (Autumn, 1992): $153-178$. 
Raibmon, Paige. Authentic Indians: Episodes of Encounter from the Late NineteenthCentury Northwest Coast. Durham: Duke University Press, 2005.

-. "Theatres of Contact: The Kwakwaka'wakw Meet Colonialism in British Columbia at the Chicago World's Fair," Canadian Historical Review 81, no. 2 (2000): 157 190.

—. "The Practice of Everyday Colonialism: Indigenous Women at Work in the Hop Fields and Tourist Industry of Puget Sound." In Unequal Sisters: An Inclusive Reader in U.S. Women's History, edited by Vicki L. Ruiz and Ellen Carol Dubois, 194 - 220. New York: Routledge, 2008.

Rafael, Vicente. White Love and Other Events in Filipino History. Durham: Duke University Press, 2000.

Reid, Kay. "Multilayered Loyalties: Oregon Indian Women as Citizens of the Land, Their Tribal Nations, and the United States." Oregon Historical Quarterly 113, no. 3 (Fall 2012): $392-407$.

Ronda, James P. Lewis and Clark Among the Indians. Lincoln: University of Nebraska Press, 1984.

Rosenthal, Nicolas G. Reimagining Indian Country: Native American Migration \& Identity in Twentieth-Century Los Angeles. Chapel Hill: University of North Carolina Press, 2012.

Rupp, Leila J. “Constructing Internationalism: The Case of Transnational Women's Organizations, 1888 - 1945." American Historical Review 99, no. 5 (December 1994): $1571-1600$.

Rydell, Robert W. All The World's A Fair: Visions of Empire at American International Expositions, 1876 - 1916. Chicago: University of Chicago Press, 1984.

Said, Edward. Orientalism. New York: Pantheon Books, 1978.

Scharff, Virginia. Taking the Wheel: Women and the Coming of the Motor Age. Albuquerque: University of New Mexico Press, 1992.

Schechter, Patricia A., Exploring the Decolonial Imaginary: Four Transnational Lives. New York: Palgrave Macmillan, 2011.

— ."Feminist Approaches to Anti-Imperialism: A Case for the Decolonial." Conference paper, American Anti-Imperialism since 1776, University of Oxford, Oxford, UK, April 29-30, 2011. 
Schlick, Mary Dodds. Columbia River Basketry: Gift of the Ancestors, Gift of the Earth. Seattle: University of Washington Press, 1994.

Sneider, Allison L. Suffragists in an Imperial Age: U.S. Expansion and the Woman Question, 1870-1929. New York: Oxford University Press, 2008.

Stoler, Ann Laura, editor. Haunted By Empire: Geographies of Intimacy in North American History. Durham: Duke University Press, 2006.

— and Frederick Cooper, editors. Tensions of Empire: Colonial Cultures in a Bourgeois World. Berkeley: University of California Press, 1997.

Thrush, Coll. Native Seattle: Histories from the Crossing-Over Place. Seattle: University of Washington Press, 2007.

Tyrell, Ian. Reforming the World: The Creation of America's Moral Empire. Princeton, NJ: Princeton University Press, 2010.

Ward, Jean M. and Elaine A. Maveety, eds. 'Yours for Liberty': Selections from Abigail Scott Duniway's Suffrage Newspaper. Corvallis: Oregon State University Press, 2000 .

Weimann, Jeanne Madeline. The Fair Women. Chicago: Academy Chicago, 1981.

West, Elliott. The Last Indian War: The Nez Perce Story (Oxford: Oxford University Press, 2009), 288-292.

White, Richard. "Frederick Jackson Turner and Buffalo Bill," in The Frontier in American Culture: An Exhibition at the Newberry Library. August 26, 1994January 7, 1995 (Berkeley 1994): 6-65.

Wong, Marie Rose. Sweet Cakes, Long Journey: The Chinatowns of Portland, Oregon Seattle: University of Washington Press, 2004.

Young, Elliott. "Red Men, Princess Pocahontas, and George Washington: Harmonizing Race Relations in Laredo at the Turn of the Century." Western Historical Quarterly 29 (Spring 1998): 48 - 85.

Yung, Judy. Unbound Feet: A Social History of Chinese Women in San Francisco. Berkeley: University of California Press, 1995. 